$\therefore$

$\cdots$ 


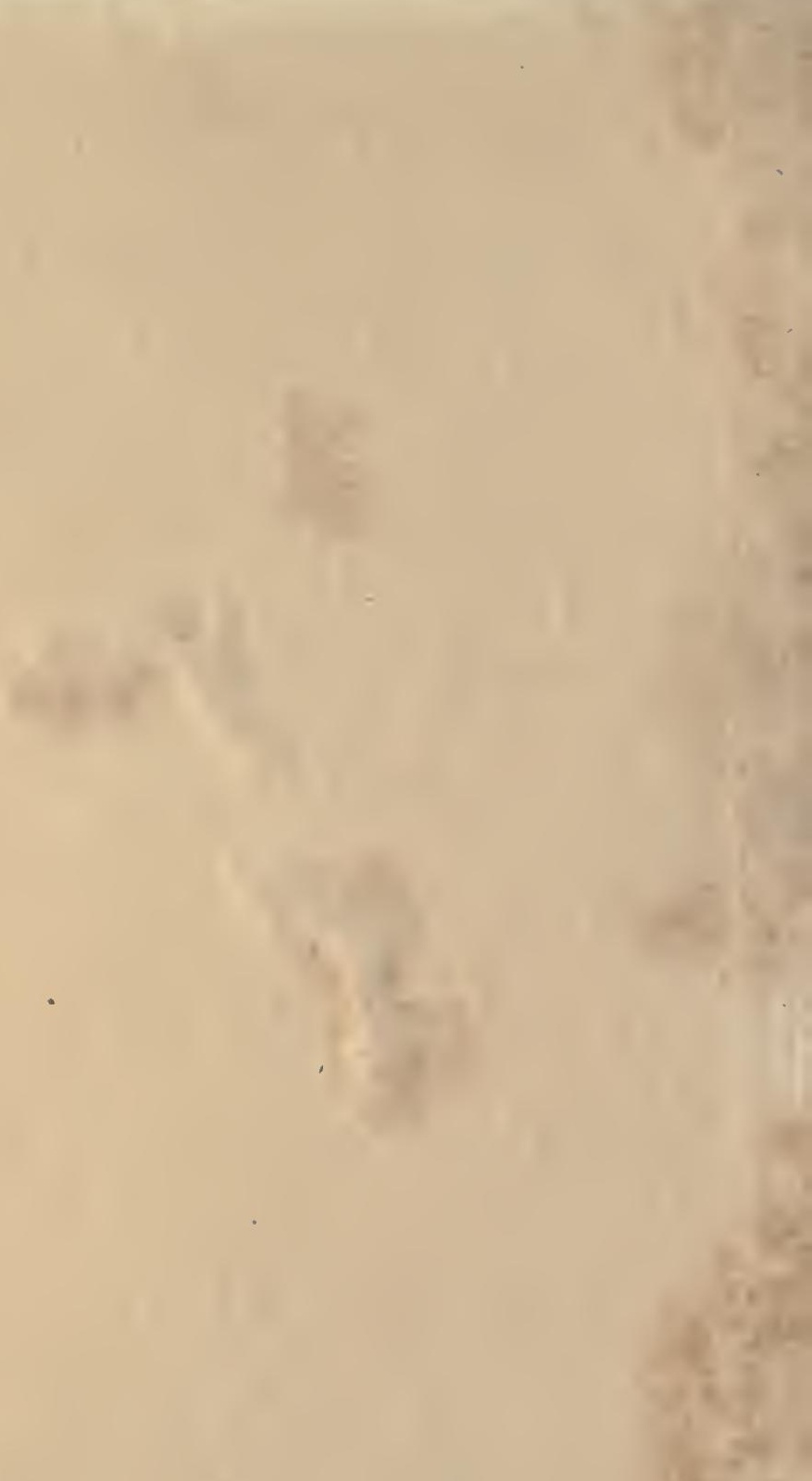




\title{
SECRETS OF
}

\section{ANIMAL LIFE}

\author{
BY \\ J. ARTHUR THOMSON \\ M.A., LL.D.
}

XEGIUS PROFESSOR OF NATURAL HISTORY IN TEE

UNIYERSITY OF ABERDEEN

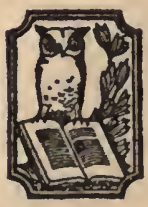

NEW YORK

HENRY HOLT AND COMPANY

1919 
Copyright, 2919

By

HENRY HOLT AND COMPANY 


\section{PREFÁCE}

THE aim of this book of short studies is to 1 interest thoughtful readers in the multitudinous problems of animal life as they present themselves to the modern biologist. Some of them deal with old problems which have reasserted themselves in new guise; others deal with new problems which recent research has brought into prominence. Most of them are confessedly appreciations of, and reflections on, the investigations of other naturalists, and most of them were, to begin with, "lectures" to senior students of Natural History in this University. It need hardly be said that the subjects chosen are only representative, and that the light thrown on them tends rather to an appreciation than to a solution of the problems involved. Nature so often tells us one secret in terms of another. The first ten studies deal with individual animals; the next six have to do with the web of life; the ten that follow raise problems of development and behavior-two subjects more intimately related than appears at first sight; the remaining fourteen 


\section{PREFACE}

studies may be grouped round the concept of evolution. All the studies appeared in The New Statesman and are published in this form with the kind permission of the proprietors and editor.

$$
\text { J. Arthur Thomson. }
$$

. Marischal College,

THE UNIVERSITY OF ABERDEEN,

January I9I9. 


\section{CONTENTS}

PAGE

I. Homing of Sea-Swallows . . I

II. A Pecultar People ? • • 9

III. Raids of the Amazon Ants . • I7

IV. Social Life of Wasps • • • 24

V. The Cawing of Rooks . • . 32

VI. Cuckoo Puzzles • • • • 39

VII. The Frog's Year • • • • 47

VIII. The Educability of a Snall • 55

IX. The Cult of Shells • • • 62

X. The Fitness of Right Whales . 7 I

XI. The Internal Economy of the

SEA . • . . . . 80

XII. Sea-Meadows • • • • $\quad$ • 88

XIII. Frankincense and Myrrh . . 95

XIV. Country Sounds . . . . 103

XV. The Fall of the Year . • . I I I

XVI. The Survival of the Otter $\because \quad 120$

XVII. MidWINTER • • . . . . . . 127

XVIII. The Microcosm of the EGG . . I34

$\nabla$

$$
2.3966
$$


XIX. The Curve of Life . . . I 42 XX. Rejuvenescence . . . I5O

XXI. The Biology of Twins . . 158 XXII. A Limb FOR A LIFE . . . 166 XXIII. LAtent Life • • • . 175 XXIV. The Storing Instinct . . 183 XXV. The Roving Impulse . . I9I XXVI. The Problem of Parasitism . 198 XXVII. WONDERS OF INSTINCT . . 206 XXVIII. Making a Home for Life - 213 XXIX. With Darwin Forwards . 22 I XXX. The Mendelian Clue . . 229 XXXI. The Fountarn of Change . 238 XXXII. Problem of Cave Blindness . 246 XXXIII. Convergence in Evolution . 254 XXXIV. Does Acquired Vigor Count? 263 XXXV. The Unseen Goal . . . 270 XXXVI. Before the Dawn of Art . 278 XXXVII. Man's Arboreal ApprenticeSHIP

XXXVIII. Sequel to "The Jukes" . 294 XXXIX. The Optimism of Pathology 302 XL. The Cult of Joy . . 309 


\section{SECRETS OF ANIMAL LIFE}

\section{I}

\section{HOMING OF SEA-SWALLOWS}

T OMING pigeons have been used by man for 1 more than two thousand years, and still we have no satisfactory theory of their usually successful return from great distances to their cots. Still less can we explain the well-authenticated fact that a swallow may return from its wintering in the south to the Scottish farm-steading where it was born the year before. The problem of homing bristles with difficulties, and it is therefore with eagerness that we turn to a record of the experiments ${ }^{1}$ which have been recently made on the sea-swallows at the Tortugas by Professor J. B. Watson and Dr. K. S. Lashley. The birds were the Noddy Tern and the Sooty Tern, which breed in tens of thousands upon Bird Key. That island of the Tortugas group was surely predestined for the experiments in question, for it is the northern limit of the migration of these two tropical terns, so that if the birds are taken anywhere to the north they will find them-

${ }^{1}$ Papers from the Department of Marine Zoology, Carnegie Institution, Washington, vii. (1915) pp. I-I04, 7 pls. 9 figs. 
selves in all probability in a region which they never before visited. Furthermore, as Bird Key is the last piece of land between the coast of Florida and the coast of Texas, the birds can be sent out to sea for hundreds of miles beyond sight of all landmarks. Between Bird Key and Galveston, for instance, there is open water for 855 statute miles, obviously a fine expanse for homing experiments.

The technique. of the experiments is as follows: A bold, vigorous tern is caught, it is marked characteristically with oil-paint on the head and neck; two tags (small and large, but otherwise duplicate) are prepared, recording the date, the place, and the kind of marking; the small tag is tied round the bird's neck; the large tag is fixed to a foot-long stake pushed down into the sand near the nest if the bird is a Sooty or tied to a convenient twig if the bird is a Noddy; the bird is put into a large hooded cage and transported to a distance on board ship; it is kept in good health with minnows from the refrigerator; it is liberated at a chosen point; and then its return to the nest is watched for. The most important general result is that these terns are able to return from Galveston, more than 800 miles away, over a body of water which apparently does not offer any basis for controlling flight direction. Some returned in about six days, some took nearly twelve, some did not return at all. Many of the return journeys from distances greater than 500 miles did not require more than three to five days, but sometimes as 
long a time was required to come from Key West to Bird Key, which is only about 65 miles. It goes without saying that the time required has nothing to do with the rate of flight, for three Sooties returned from Key West in 3 hours 45 minutes, and probably spent part of that time on the feeding ground before reporting themselves at the nests. The success of the homing depends partly on the vigor of the birds and partly on the smiles of fortune, as expressed, for instance, in a spell of fine weather and the absence of hawks.

It is instructive to give particulars in regard to some of the experiments. Two Noddies and two Sooties were taken in the stateroom of a steamer to Havana, and liberated in the harbor there early in the morning of IIth July. They returned to Bird Key ( 108 miles off) next day, having probably spent most of the time recuperating around the shores of Cuba. Of five birds liberated off Cape Hatteras at least three returned in a few days, having accomplished a journey of 850 miles as the crow flies, and of much more if the alongshore route was followed. Four Noddies and four Sooties were taken in a hooded cage on a Galveston steamer to about 46I statute miles from Bird Key and liberated where no shore line was visible. "On release all birds with one exception started east. That one headed west and continued for about 200 yards, then turned suddenly and started east." They had a strong head wind against them through- 
out the first day, but two of the Noddies returned in safety to Bird Key. On 4th June eleven birds were liberated in Galveston Harbor; on 9th June one of the observers, returning to Bird Key on the steamer, saw one of his terns (a red-marked Sooty) resting upon a piece of driftwood in the open sea about 409 statute miles east of Galveston. A heavy storm unfortunately removed all chance of its successful return.

The authors are not prepared to offer any solution of the problem of distant orientation in birds, but they have made a distinct step in proving that untrained birds can return successfully across the apparently trackless sea from a distance of 800 to I000 miles. Dr. Lashley has shown that for short distances on the island itself the terms adjust themselves to nest and mate and young on a basis largely of visual experience, helped a little by memory of movements, and sometimes by sounds. There is no whit of evidence of any unusual sensitiveness nor of the functioning of any hypothetical senseorgan.

But what can be said in regard to distant orientation? (I) It has been suggested that the Cape Hatteras birds followed the coast-line in the direction of greater warmth. This is possible enough, but it does not bear at all upon the flight from Galveston to Bird Key across the Gulf of Mexico. (2) It has been suggested that the Galveston birds followed a well-marked water-current which sweeps around the coast of Texas, Louisiana, Alabama, Florida, 
and out past Tortugas through the Straits of Florida. The current differs in color from the surrounding water and from the return current which runs nearer the coast-line. But the color difference is only noticeable when the sun is in a certain position in relation to the observer; many of the successful birds were liberated at night, and all were out for several nights; they had to win their way home through rain, haze, and cloudy weather; they homed equally well, no matter at what point between Galveston and the Tortugas they were put down. And besides, why should they not follow the current in the opposite direction? (3) It has been suggested that the birds get their bearings visually by ascending to a great height. But, in the first place, they never seem to rise very high; in the second place, they would require at a distance of 100 miles to ascend almost a mile to see the Loggerhead Key lighthouse; and, in the third place, even if they ascended they would not see much because of the continuous haze.

The observers are not inclined to assume any new. and mysterious "sense of direction" until they have made many more experiments, and a good beginning has been made. Thus, to meet Duchâtel's hypothesis that the retina of the bird is specially sensitive to infra-luminous rays, especially infrared, Professor Watson made a special investigation of spectral sensibility in the chick and the homing pigeon, and found no evidence at all of the supposed susceptibility. Care was also taken to test 
Cyon's theory that birds (notoriously deficient in the sense of smell of the ordinary kind) nose their way home through the air, feeling the direction, strength, and temperature of the wind as it plays on the olfactory mucous membrane. The nasal chambers of two Noddy terns were filled with warm wax and varnished over, and the birds were sent to Key West, 65 miles distant, where they were released at two o'clock in the afternoon. At daybreak next morning both birds were on their nests just as usual. Thus it may be inferred that there is not in the nasal cavity of terns any special tactile or olfactory sensitiveness which functions in the homing. The observers propose to inquire whether there may be on other parts of the body-such as eyelids, ear-covering, mouth cavity-any tactile or thermal nerve endings which may assist the birds in reacting to slight differences in pressure, temperature, and humidity which they may encounter on their flight.

So the matter stands at present-the remarkable fact of untrained birds successfully reaching from a great distance a known but invisible goal surrounded by apparently trackless sea. It goes without saying that there are speculative theories galore, but what Professor Watson and Dr. Lashley are working towards is a scientific interpretation. Naturalists have appealed to magnetic sense, topographical memory, registration of movements, telepathy, and so on-at least nine theories have been advanced -but the solution of the riddle is still in the future. 


\section{HOMING OF SEA-SWALLOWS}

It is a familiar step in scientific method to try to bring an obscure fact into line with others of an approximately similar kind, and this must be done in the case of the homing terns. In this connection it is unfortunate that the data in regard to homing dogs and cats and other mammals are not in a form suitable for scientific purposes, and that crucial experiments to show what untrained homing pigeons can do are lacking.

Exceedingly careful experimental work has been done with ants and bees, which find their way home successfully within a limited radius, and the balance of evidence inclines to the conclusion that most of the phenomena can be explained by the gradual registration of various sets of stimuliolfactory, tactile, visual, and kinæsthetic. Here also, however, there are residual phenomena at present as inexplicable as the homing of the terns from Galveston to the Tortugas. Professor Watson holds the chair of Experimental and Comparative Psychology at the Johns Hopkins University, and his experimental study of the homing terns is marked by a greater psychological subtlety than is usually to be found in the adventures of zoologists in similar fields. Thus it is interesting to notice his careful observations on the duration of the nesting impulse when the normal activities have been interrupted. He finds that it remains strong for two or three weeks; and this should be borne in mind, for it gives an illuminating significance to the homing of the sea-swallows. They are returning to their nests, 
that is, to activities in which their life reaches its climax, to the continuance of which they are impelled by a deep organic urge, by an irresistible impulse which is not balked by any waste of seas. 


\section{II}

\section{A PECULIAR PEOPLE}

THE story goes that a lady seeing penguins for the first time, and that, as it happened, in the sea-lions' inclosure at the Zoo, remarked that it was strange that the young seals were so like birds. She might well be excused for an error that showed an unprejudiced mind, for quainter creatures than penguins it would be hard to imagine. Their striking attitudes, now upright like sentinels and again groveling on the ice like their reptilian ancestors; their versatility in movement, gamboling like porpoises, swimming like ducks, diving with the help of their flippers to a depth of ten fathoms, toddling on the ice like topheavy babies, and tobogganing in a manner all their own; their daring surrender of wings in exchange for flippers; their way of molting their feathers in great patches; and a score of other remarkable features mark them out among birds as a very peculiar people. But it is when we inquire into their habits that their most striking peculiarities are discovered, and here we are especially indebted to Staff-Surgeon Murray Levick, R.N., member of the "Terra Nova" (rgro) Antarctic Expedition, who has got nearer the heart of the penguin-of the 
Adélie species at least-than any previous observer. The work of Dr. Edward A. Wilson, whose untimely death was such a loss both to science and art, remains a model of accuracy and thoroughness, but Dr. Levick has gone further. He has previously written a delightful popular study of the social habits of the Adélie penguins (Heinemann, I914); what we have before us now is an excerpt (I9I5) from the first volume of the British Museum Report on the zoological discoveries of the "Terra Nova" Expedition. It is entitled Natural History of the Adélie Penguin, and is illustrated with twenty-one remarkable photographs. It is a study which any naturalist might be proud of, and it shows the author to be an observer of the first rank. The observations appeal not only to those who are keen on birds, but also to those who are interested from the philosophical side in the deeper problems of natural history. "You of any well that springs," said Meredith, "may unfold the heaven of things," and it is extraordinary how "far ben" into biology Dr. Levick's careful study leads us.

Towards the middle of October, a single Adélie penguin was seen on the rookery at Cape Adare. Two days afterwards there were two, and next day about a score, and next day "as we looked across the sea-ice to the northwards, we could see a long line of Adélies approaching, tailing out in snakelike fashion, as far as the horizon." This is the first picture, the return of the penguins to their birthplace. Dr. Louis Gain of the Charcot Expedition 
has proved that some at least return to the same rookeries year after year to breed; and here we are out of our depth at once when we think of the mysterious nostalgia that brings these flightless birds back to their cradle over hundreds of miles of trackless sea. When they get agoing on the ice they toddle hurriedly, one hundred and thirty steps per minute, six inches at a step, two-thirds of a mile per hour. "In the still air their little wheezy respiration could be heard distinctly, and they seemed to be somewhat out of breath." Every now and then they suddenly flop forwards on their breasts and take to tobogganing at the same rate as before, using their legs as propellers. By the end of the month the rookery at Cape Adare was crammed with some three-quarters of a million birds.

The hens take possession of the old stone-nests or scoop out new hollows in the ground, and waitsometimes rather forlornly-for proposals. A cock, struggling against the drowsiness engendered by the long journey, rouses himself to action, and makes as if to place an imaginary stone at the hen's feet, "a most obvious piece of dumb show." But the hen often answers never a word, and it requires a duel between rival cocks to arouse her interest. The combatants lean their breasts against one another and rain in blows with their flippers. In many cases blood is drawn, but Dr. Levick never saw a fatal encounter. During the first days of wedded life the cock has continually to make good his claim by driving off interlopers, but after the 
pair settle down they remain perfectly faithful to one another.

The nests are made of rounded stones which the cock collects, stealing them when he can. Jagged pieces of quartz seemed to be irresistible, the æsthetic triumphing over comfort, and there was an eager demand for Dr. Levick's painted pebbles, red being preferred to green. A very interesting feature was the entire avoidance of a big knoll rising from a shallow lakelet by the beach. The water was frozen hard when the penguins arrived, but the wise birds seemed to realize (or was it some taboo-tradition?) that in some six weeks' time they would not be able to reach the knoll save by wading through muddy water slimy with guano. - On other situations the nests were occasionally built too low, and a good deal of energy had to be subsequently expended in raising them with extra stones as the thaw-water accumulated. A pretty incident was once seena cock bringing a lump of snow for the hen to eat. "The cock, when away from his mate, evidently had in his mind the fact of his hen being thirsty and unable to get snow as he could." It is characteristic of the Adélie penguins to climb heights and nest on cliffs. Some of them, coming straight from the sea, make at once for the heights, and climb laboriously from ledge to ledge. Do they meet their last year's partners at the summit? Dr. Levick found a colony at the very top, about 700 feet above the sea, a site which involves prodigious toil. "During the whole of the time when they are rearing their 
young, these mountaineers must make several journeys during each twenty-four hours, to carry their enormous bellyfuls of Euphausia all the way from the sea to their young on the nests-a weary climb for their little legs and bulky bodies, each upward journey taking them some two hours of strenuous climbing."

Not until the eggs have been laid does either parent go to feed. Then one of them goes off to the water and stays away in many cases for seven to ten days, after which it returns and gives the other its leave. The shortest period of total abstinence from food is about eighteen days, and the longest about twenty-eight days - a good instance of the parental sacrifice so characteristic of many of the finest expressions of animal life. When the chicks are hatched, the parents relieve one another at frequent intervals, and their shape, always quaint, becomes grotesque when they return so heavily laden with crustaceans that they have to lean back to keep their balance. Sometimes they try to carry so much that they lose it all. The chicks feed, as young cormorants do, by thrusting their head into the parental gullet. When the hen is sitting, nothing, not even a wrangle with her next-door neighbor, will induce her to move until her turn comes; but the cocks are easily led astray by their combativeness, and often do a lot of harm in the crowded rookery in spite of the protests of adjacent birds who are seen trying to make peace.

In the water the Adélie has but one enemy, the 
sea-leopard, and out of water none that is deadly save man. The penguins take no particular notice of the killer-whales, but they have a mortal terror of the sea-leopards, who sometimes swallow them whole. These voracious Pinnipedes often lurk below the ledge from which the penguins dive, and Dr. Levick gives us a glimpse of another side of penguin nature when he tells of the tricks the birds play to get one of their number to be the first to go into the water. Apart from the sea-leopards, man, and one another, the adult penguins live at peace, but terrible damage is often done at thawtime by falling boulders and land-slides. Sometimes, too, crowds of nesting birds are buried in snow-drifts which are especially serious when they freeze on the surface. But even then the tough creatures can survive for many weeks within little chambers thawed by the warmth of their bodies, and provided with breathing-holes through which they thrust their heads. On the whole, the adult birds are very safe, but among the eggs and the young the mortality is high, for which the voracious skuas and the recklessly combative or even vicious cocks are largely to blame.

There is a lighter side to the life of the penguins, for they have developed a taste for certain primitive games which they play on the sea-ice on their way to and from their bathe. There is the diving, in which the succession is so rapid "as to have the appearance of a lot of shot poured out of a bottle into the water"; there is the "porpoising," the 
leaping out of the water, and the game of "touch last" on the sea-ice. A favorite ploy was to board an ice-floe till it would hold no more, and get carried by the tide to the lower end of the rookery, where every bird would suddenly jump off and swim back against the stream to catch a fresh floe and get another ride down. To find the time for all this fun without leaving the chicks to perish, a strange device has been evolved. The parents " pool their offspring" in groups which are left in charge of a few conscientious persons (there is great individuality among the members of the penguinery) who ward off the skuas and keep, or try to keep, the chicks from straying. The holidaying parents bring food at intervals, when their conscience smites them-and they remain faithful to their own crêches. On the whole, the Adélie's lot appears to be a happy one, and we read with pleasure of the "ecstatic" attitude which they assume, and the weird "chant de satisfaction" which they utter when all is well with their world.

Oné other picture is surely unique in the annals of natural history. It was a sort of drilling on the ice, a congregating of thousands, and the execution of ordered movements for hours on end. Dr. Levick's interpretation is probably correct, that although what he saw was not directly connected with migration, it may represent an echo of a bygone habit of massing together in large numbers before the autumnal journey northwards. The journey is, of course, still undertaken, but little 
is known of it, for the winter-quarters of the Adélie penguins after they leave the Antarctic shores are wrapped in blizzard and mist, though they probably lie near the northernmost limit of the pack-ice in the fa: southern seas. 




\section{RAIDS OF THE AMAZON ANTS}

MOR more than forty years zoology has been continuously enriched by the observations of Professor Carlo Emery, an Italian naturalist, who has grown old in the service of entomology and in the study of ants in particular. One of his recent papers (1916) reports on fresh investigations of the European Amazon ant, one of the handsomest and most bewildering of pismires. To appreciate Emery's advance we must recall the main facts of a strange story. Transitory mixed colonies of two species of ants are not very uncommon; they lead on to cases like the blood-red ant, Formica sanguinea, a gifted, belligerent creature which usually makes slaves of the workers of other species, but can thrive well enough without them if it chooses. Very different from these sanguinary ants, as they may be called, are the degenerate slave-holders and the social parasites, which are altogether dependent on their slaves or hosts. But between the degenerate forms which have surrendered independence for ease, and the sanguinaries which can be independent if they will, are the Amazons. They cannot live without slaves, and 
yet they have not so far become in any marked way degenerate.

The European species, Polyergus rufescens, was first recognized as a slave-owner by the Swiss entomologist Pierre Huber (in 1810 ); his fine observations were extended by his fellow-countryman Auguste Forel, also working on the shores of the Lake of Geneva; and now Professor Emery has added to the story. The American Amazons have been best studied by Professor W. M. Wheeler. ${ }^{1}$ The Amazon workers and queens have jaws well-suited for killing but ill-suited for burrowing, or obtaining food, or tending the young. They cannot dig, but to beg and to steal they are not ashamed. They are militarist aristocrats who will not soil their hands with toil. As Professor Wheeler puts it: "While in the home nest they sit about in stolid idleness or pass the long hours begging the slaves for food or cleaning themselves and burnishing their ruddy armor, but when outside the nest on one of their predatory expeditions they display a dazzling courage and capacity for concerted action compared with which the raids of the "sanguinary ants' resemble the clumsy efforts of a lot of untrained militia." But they have paid for their combative accomplishments dearly, for they cannot live without their auxiliaries or hosts or slaves. We use all these words because no one of them alone will serve to denote the strange association. ${ }^{1}$ See his fascinating and reliable book-Ants (Columbia University Series). 
It will be borne in mind that, apart from the reproductive "queens," the actively militarist creatures we are concerned with here are all non-reproductive females, the so-called "workers."

A notable step was taken by Emery in 1908 and 1909-namely, the starting of an experimental nest. He introduced a fertilized queen Amazon into one of M. Charles Janet's formicaria which was inhabited by a colony of Brown Ants. One of the first events was that the Amazon queen slew the Brown queen, and was enthroned in her stead. In the course of two years-we must omit the details-Professor Emery had a flourishing colony, consisting of Amazons who had never been outside the walls and a serviceable number of Brown slaves. The importance of the experiment is evidently that it shows how a mixed colony of Amazons and auxiliaries may arise. In the early days of the colony in question the slaves treated the Amazons as if they were pets; they would not let them even take an airing in the illumined part of the formicarium, and if one escaped it was quickly brought indoors again. By and by, however, the Amazons became more numerous and fidgety ("remuantes"), and one after another set out on scouting expeditions. When we remember that they were exploring a new world we cannot but be amazed that a solitary scout, discovering a nest of Brown Ants, should forthwith enter, attack the crowd of workers, seize a cocoon, and carry it home." Instinct must have its way. 
In the summer of I9II, after scouting had continued for some time, Emery noticed one afternoon a growing excitement, and the issue of a platoon of sixty Amazons. But they only went a couple of yards or so, and then returned. About an hour afterwards there was another sally which made straight for a colony of Brown Ants and came back laden with prisoners (babies and children as usual). Going and coming several times the Amazons got over 450 prisoners that evening. In 1912 and 1913 , Emery continued working with his artificial nest which he shifted hither and thither (a method likely to be very useful in tackling myrmecological problems), and he confirmed Forel's description of the rapidity and precision of some of the predatory raids. This probably depends in part on the previous reconnoitering, and it seems likely enough that a scout who has discovered a suitable object of pillage may give the direction to the raiders, if it does not actually lead the way. In one instance, reported by Forel, the nest to be pillaged was at a distance of over 16 feet, but the Amazon army went straight for the goal.

A most extraordinary case was long ago reported by Ebrard. One forenoon he took home a nest of common ants and their cocoons, inclosed in a carefully tied handkerchief, and deposited it in a room on the second story, meaning to give the warblers in his aviary a treat. In the course of the afternoon, on returning from a walk, he found his servants in a state of great excitement, for the house 
had been invaded by legions of Amazon ants which had made their way upstairs and pillaged the precious handkerchief, carrying off the cocoons meant for the singing birds. The probability is that a wandering Amazon scout had discovered the treasure in the napkin and had carried the news to headquarters. Hence the raid-prompt, precise, and resolute; and our admiration for the Amazons grows.

In one of Emery's experiments, the artificial nest was placed in a walled court with no trace of desirable objects of pillage. Yet there were repeated expeditions. Were these prompted by the victims of illusion, who "believed they had discovered ant nests where none existed"? This being. absurd, Emery would have us note that his particular colony had been transplanted into a terra incognita, where, naturally enough (are we not poignantly aware of analogous cases in human warfare?), the expeditions were a little fatuous. In an established Amazon colony, however, mastery of the environment is soon attained, and the raids are swift and sure. We do not hold up Amazon ants as ideals for mankind-or should we not say womankind in a case like this?-but we confess to some admiration for their promptness, precision, courage-and success. It is rather a despicable business this kidnapping of children for slavesbut the Amazons do it well. In one raid which began about five o'clock in the afternoon, over a thousand prisoners were taken before quarter to 
seven, when Professor Emery's son stopped counting. It seems likely that the Amazons are moved by an instinctive restlessness, which becomes periodically irrepressible, and leads to the impetuous raids, which, by the way, are almost invariably confined to the afternoon.

In I9I4 the veteran observer made a study of a flitting from one nest to another. On the first afternoon the Amazons were seen carrying their slaves, sometimes in contradictory fashion in opposite directions; but after that the slaves did most of the work of transporting the young, and even carried their mistresses. On another occasion Emery saw an unusual sight, perhaps a mutiny, but more probably a madness. Several slaves attacked an Amazon and began to pull her about; she slew two of them forthwith, but was soon afterwards attacked by another Amazon, and there ensued a quarrel fatal to both. Next day the slaves were seen carrying off the two bodies.

Like Huber and Forel before him, Emery puzzled over the resistance that the auxiliaries often offer to the issue of an expedition of Amazons. Forel suggested that the young auxiliaries, brought in from outside, have to become accustomed to the strange proceedings before they can acquiesce in raids as part of the order of the day. Emery suggests, however, that there is something subtlernamely, "a myrmecophilous relation"-that the servants hold their mistresses as something like wayward pets. He admits, however, that in the 


\section{RAIDS OF THE AMAZON ANTS}

course of the summer this relation wears rather thin. One is tempted to recall the way in which the servants carry their strayed mistresses home, or the influence of evil communications seen in the fierceness which sometimes infects the timid Brown Ants, and leads them to share in the slave-making. But our last note on this weird under-worldfull of warning and caricature-must be the sad question whether these intrepid Amazons are doomed in the course of evolution to the degeneration which has beset other emmets who have played with their independence. 


\section{SOCIAL LIFE OF WASPS}

QURELY in the jetsam of the autumn's ebb$\checkmark$ tide there is no more eloquent item than that wasps' nest in the gooseberry bush-empty since the morning frosts of early September. Most people hail "the last of the wasps" with considerable satisfaction, and even their champions must admit that there are limits to their relevancy; yet we never see their autumnal dying-off without giving them our admiration. Laying aside a colossally absurd prejudice, who can fail to appreciate the workmanship of that familiar hanging edifice, often as big as one's head, an elegant house of paper, fabricated from salivated shavings planed from fences and disbarked branches? There we see story hung from story, with perfect economy of space and security of ventilation; a compacted framework of hundreds of cradles rivaling the honeycomb of hive-bees; and outside it all a series of rainproof and windproof envelopes.

Some biologists have said that animals use matter constructively inside their bodies, whereas man brings matter into his service extra-corporeally. This is going much too far, however, for there are many of the more adventurous animal types-but 
for whose pioneering Man might never have been -that undoubtedly bend matter to their will outside their bodies. Think of the nest-builders like the house-martins and weaver-birds, the netmakers like the spiders, the home-makers like the termites and beavers, the trap-contrivers like the larval ant-lions, the store-accumulators like the bees, the bed-makers like the anthropoid apes, and so on, not forgetting, as a sort of climax, the honeymooning bower-birds. It may not be "art" that these creatures show, but there is no doubt as to their triumphantly skilful use of materials. Samuel Butler declared that animals have tools which are part of them and cannot be laid down; whereas man has limbs which are apart from him and detachable. Which is, in the main, good sense. But whether a living creature planes with a tool or with its mandibles, it planes; and that requires skill. And the planing is only the first step toward the wasp's nest, which, taken objectively, is a far finer thing than many a human erection which entitles its tenant to a vote.

And it is not only the architecture of wasps that commands our admiration; there is the coherence of the large family or community, sometimes numbering several thousand members; there is the creature's strength, displayed in lifting a dronefly half its own size off the ground and carrying. it through the air; there is contrivance in cutting off the wings of a big insect before it tries to transport it through the air; there is the uncanny 
power of flying backwards in front of one's bicycle for a quarter of a mile at a time; there is the consummate efficiency (incalculably beneficent from man's point of view) in destroying in a great variety of ways large numbers of injurious insects-for wasps are carnivores and scavengers of big appetite, as well as the honey-suckers, fruit-eaters, and jamthieves we all know them to be.

But, tearing ourselves away from these familiar wonders, we wish to direct attention to a quaint piece of domestic economy which Dr. Roubaud has recently discovered among African wasps. These know no winter or interruption in their year, and they throw fresh light on species like ours which are severely punctuated by northern seasons. For it is well known that of the great summer community of wasps only the young fertilized queens survive the winter. They have sought out sheltered nooks, under thatch and the like, where, fixed by their jaws, and occupying a position quaintly like that which they had as pupæ within their cradles, they lie asleep till the spring.

Among bees and wasps there has been social evolution on a primarily instinctive and secondarily intelligent basis-rookeries and the like being on a primarily intelligent and secondarily instinctive basis; our evolution being on a vaguely instinctive, primarily intelligent, and occasionally rational basis. There are many solitary wasps and solitary bees, and there are many grades of sociality, or whatever it be called, between the solitary life and 
that of the bee-hive and the wasps' "bike." In the social evolution of these Hymenoptera there have evidently been two divergent lines-one towards honey-storing and the other towards predatory alimentation. The honey-storing régime has its climax in hive-bees, with many gradations leading up to that pitch of perfection; and down at the base of this line it seems that we must, for anatomical reasons, include the solitary digger wasps (Sphegidæ), which store paralyzed insects and spiders for their larvæ. The predatory régime has its climax in some of tropical social wasps, while many others, not less predatory, called Eumenids and Pompilids, remain at the solitary level. And just as the predatory digger-wasps or Sphex-wasps, mentioned a moment ago, seem to go with the bees, so there is a family of "honeywasps" (Masarids) which go with the main body of the wasps, though they do not practise the paralyzing device, and are, indeed, vegetarian, both as larvæ and as adults. The predatory régime appears to be the more primitive of the two, and it has been suggested that honey-storing was resorted to by types whose poison was not suited for the preservation of animal food. In any case, the broad fact is that social organizations have been evolved on the hive-bee line of storing honey and on the social-wasp line of supplies of fresh meat. There has been an interesting dichotomy of vegetarians and carnivores!

According to Dr. Roubaud, the first chapter in 
the social evolution of wasps is illustrated by some of the Diggers and Pompilids, where the mother makes for her larvæ a larder of paralyzed victims, but has no further commerce with her brood. She quickly makes a store of preserved (indeed, living) flesh and has done with it. The second chapter is seen in some African Eumenid-wasps, in which the mother brings freshly-paralyzed victims from day to day as her hatched larva has need of them. There is more of a personal touch here, for the mother comes into intimate relations with her offspring, and seems to know it as hers. The third chapter shows an abandonment of the paralyzing device, the poison not being used except in killing the naturally recalcitrant victims. The prey is more or less masticated into pap, the mother retaining a tithe for herself, and the result is laid beside the larva, whose mouth, it is very interesting to notice, has ceased to have much power of chewing.

But some very curious features now come to light, that the salivary secretion of the larva becomes greatly exaggerated, as sometimes happens in man; that it tends to overflow at the mouth; and that it is for the mother "l'objet d'une recherche particulière." It is the sop that keeps the motherwasp self-forgetful, corresponding to the look in a baby's eyes that keeps a human mother from utter weariness. The nurture of a single larva, distributed over a considerable time, leaves the mother-wasp with the gift of leisure, and there are gradations 
showing how this is utilized in increasing the family. The simultaneous nurture of a number of offspring means more work, but it also means more salivary juice, which is an elixir of life to the mother-wasps. Roubaud's theory, perhaps an exaggeration of a truth, is that the attractiveness of this secretion has been the principal factor in the social evolution of wasps. The nest has for its "end," whatever that may mean, "a rational exploitation of the larvæ," and its régime is such that a constant supply of newborn wasp-babies is kept up. For only the young larvæ secrete the elixir. A system of nutritive exchange (œcotrophobiosis it is quaintly called) has been established, mothers and children playing into one another's hands. Just as tailor-ants use their children as needle-and-thread, so these wasp-mothers obtain from their offspring those luxuries which for animal as well as for man often mean more than necessaries.

It is hopelessly difficult for man to get mentally into touch with wasps, for our lives and theirs are run on quite different methods, which Sir Ray Lankester has spoken of as the "little-brain" and the "big-brain," the instinctive and the intelligent, lines of evolution. Yet we venture to think that further research will show that Dr. Roubaud's theory is not altogether sound. We would suggest that what he exaggerates into the main motive is only the sop, the douceur, the encouragement, which, organism being what it is, remains even unto the end an exceedingly desirable stimulus of altruism. 
There are, as we have seen, thoroughly solitary wasps, and there are those that form a community. Between the two there are wasps that build their nests in close proximity-each making its own, however-and there are wasps that hibernate in companies. That this gregariousness may be of protective value is practically certain, but it is very unlikely that the social state was reached along this line. Roubaud's view is that the social life had its beginnings in "filial associations." Daughters were hatched in the nest while their mother was still about; if the stores were abundant and if there were plenty of younger sisters to supply elixir, then it would be easier for the elder daughters to see their way to remain at home and collaborate with their mother in the nurtural task. As Verhoeff also has maintained, the wasp-community is not the outcome of grouping, but of filial association, and Roubaud's addition (toned down a little) is that the elixir makes the corporate life run smoothly. We must remember that we are dealing with arrangements of prodigious antiquity, for wasp societies date back to Oligocene ages (perhaps two million years ago), and are thus much older than human societies. There has been plenty of time for experimenting.

To those who would puzzle over origins the case of a primitive social wasp called Belonogaster is peculiarly instructive. In hard times the Belonoyaster queen reverts to the solitary régime and brings up only one larva at a time. When things 
are going better, yet not too well, the young females remaining at home have to work so hard and on such scanty food that their reproductivity is hindered. Although fertilized they are slow to lay. They continue helping their mother-and they thus almost originate a caste of "workers"! Such polygynous or many-queened communities are restricted to warm countries where nesting continues all the year round. In cold countries the communities are always monogynous, i.e. there is but one functional queen. The workers remain more or less completely sterile. The queens of next year. are the young females hatched near the end of the season, which, as we have already mentioned, spend the winter in safe retreats. It is interesting to think that the establishment of the monogynous society was probably Northern and relatively recent, being imposed upon wasps by climatic conditions. It is interesting also, though very grim, to recognize that the general massacre of the wasp-larvæ in autumn, when further nurture is hopeless, is not incongruent with the "œcotrophobiosis." For the young creatures that can no longer furnish elixir are not to be wasted. They are eaten up, and it is on the strength of them that the wintering young queens are able to sleep for many days without food, and to begin the cycle again next spring. It is altogether a very economical kind of domestic economy. 


\section{Vi \\ THE CAWING OF ROOKS}

$7 \mathrm{HE}$ cawing of rooks is one of the characteristic 1 sounds of spring, and it is one of good cheer. There is vigor in it and exultation in the victory of life over materials, for the building of big nests on the delicate branches of the swaying tree-tops is a real achievement. The cawing is the voice of strong-willed mates and of jealous parents. It is more than the babel of a crowd; it is the vociferation of big-brained creatures that have got past simple gregariousness, and live in what is more than the adumbration of a society. We like it too because it is one of the earliest awakening voices of spring. As the child's poen says:

Buds of green on branch and stem Glisten in the morning sun,

For the crows have wakened them, And they open one by one.

We have been listening these days to the cawing of the rooks, and they certainly have a considerable vocabulary. There is probably no language in the strict sense-man has a monopoly of that; but the rooks have words just as dogs have, definite uttered sounds which have definite meanings. Words are 


\section{'THE CAWING OF ROOKS}

uttered when we move suddenly beneath the trees, and other words are uttered when a bird intrudes on the precincts of a neighbor's nest; there is a word when the rook sinks down upon the nest, and another word when it flies clear of the rookery and makes for the fields. What danger-signals, what scoldings, what satisfaction, what exultation, what reproaches, what encouragements do we not hear? There is no doubt that the members of the crow family have fine brains and a notable power of vocalization, which training, as in jackdaws and ravens, may develop to a remarkable degree; the finely innervated musculature of the voice-box (or syrinx) is more highly differentiated than in the master-songsters, such as blackbird and mavis. Experts tell us that the rook has between thirty and forty notes, which can be intricately combined. This may be best appreciated at the roosting-place after, the busy breeding season is over and summer has come. "A marvelous medley," said Mr. Edmond Selous in his delightful Bird Watchings, "a wonderful hoarse harmony. Here are shoutings of triumph, chatterings of joy, deep trills of contentment, hoarse yells of derision, deep guttural indignations, moanings, groanings, tauntings, remonstrances, clicks, squeaks, sobs, cachinnations, and the whole a most musical murmur. Loud, but a murmur, a wild, noisy, clamorous murmur; but sinking now, softening-a lullaby. 
We shall appreciate the cawing of the rooks better if we inquire into the story of "the black republic in the elms." It is in February that the rooks' spring begins, for then there is the courting. This takes place, not once in a lifetime, but every spring, between mates who have been married for years. For they seem to be monogamous. The cock-bird struts and bows before the hen, and spreads his wings and tail. Moreover, as Gilbert White observed long ago, "rooks, in the breeding season, attempt sometimes, in the gaiety of their hearts, to sing, but with no great success." It should be noted, however, that the singing, the bowing, and the tail-spreading are not restricted to the time of courtship, but may be indulged in at any time of excitement or jollity. Very interesting is Mr. F. B. Kirkman's note that the male bird sometimes brings a tit-bit to his desired mate, which she accepts "with quivering wings and stifled thanks." This offering of love-gifts occurs sporadically among animals. It is part of the ritual which aims at working up the female's excitement, and in the case of the rook and many other birds it finds a second expression, probably the primary one, when the male brings food to the nesting female and to the nestlings.

The courtship is followed, early in March, by the preparation of the nest. An old nest may be used over again after a thorough spring-cleaning, or a fresh one may be built. As every one knows, there is a good deal of vigorous quarreling over the 
possession of old nests or of new sites; and up to a certain point there is stealing of materials. This necessitates one bird mounting guard while the mate collects, the division of labor alternating. Very remarkable is the frequent destruction of nests that are built on trees in the outskirts of the main colony, as if the sense of the community insisted on maintaining a close gregariousness. One tree may have to carry as many as thirty nests, and it is usual to see about a dozen. The nest is built of both dry and supple twigs, with the addition of earth and clay, and the inside of the cup is made soft with grass and leaves, hair and wool. Among the favorite trees are ash, elm, beech, Scots fir, and sycamore; and it has been observed over and over again that trees which betray insecurity are abandoned by the rooks even after the nests have been built. A forsaken tree is doomed, and this may be one of the facts that have given basis to some of the superstitions about rooks.

The eggs are interesting biologically because of their great variability in coloring-that is to say, in relatively safe nesting-places, where inconspicuousness or the opposite is of little moment, natural selection has imposed no limits on variation. After the laying, towards the end of March, the mother bird sits close, the male occasionally relieving her. There is no more returning at night to the communal roosting-place, which is usually quite apart from the rookery; all the rooks keep vigil by their nests. "Relatively safe," we said, for 
raids by carrion-crows and other non-social members of the family Corvidæe are common, and are sometimes so successful, in spite of the strength of unity, that the rookery is deserted. It looks as if the rooks were not very good fighters, though they do to herons what carrion-crows, hoodies, and ravens do to them. Perhaps, for all we know, it was some weakness or softness of character that led rooks to become the most social of European birds, for apart from the jackdaws, which are so often their satellites, the other members of the race to which they belong are solitaries and individualists.

When the three to five eggs hatch, the parents have to be busier than ever, for the appetite of the young birds is large. Big mouthfuls of grubs and wireworms and the like are brought in, making a pouch-like bulging below the tongue; and at this time the rooks do so much in the farmer's interests that we should not be too hard on them for their depredations at other times. In his splendid British Bird Book Mr. Kirkman quotes from Mr. Phil Robinson the interesting observation that, to begin with, the male bird gives the food only to the female, who passes it on "doubly peptonized to the babies," and that later on both parents feed the young. "But it is most extraordinary to notice how the young accept it from the father without any demonstration, sometimes in complete silence, while every time the mother approaches they lift up their voices in a chorus of jubilation." One would like to hear more of this matter. Every one 
knows that the rook differs from the crow in habit and color, in the loss (after the first year) of the feathers round the back of the beak, and so on, but it is instructive, as an illustration of the way in which specificity penetrates through and through a creature, that while the inside of the mouth is always pale flesh-color in the young of the carrioncrow, it is first dark flesh-color and then slaty in the rook.

In many parts of the country it'has been the custom to watch the rooks with particular interest at Easter-time, for from the manner of their flight and the mood of their cawing, hints of coming events were believed to be obtainable. But most of those who watch rooks to-day find sufficient interest in their present and past. We wish one of those ornithologists who give us admirably intimate studies of the "Home Life" of particular birds would make a detailed critical study of the rook. There are so many points of great interest. Like many creatures well endowed with brains, rooks exhibit what must be called play. There are gambols and sham-fights, frolics and wild chases, in which, curiously enough, jackdaws and lapwings sometimes become keenly interested. But who knows the real truth about rooks posting sentinels, which is so often alleged? What has been called the "ecclesiastical air" of the rook, enhanced by the white about the head, gives spice to an apparent humorousness, and there is no doubt of their wisdom. But who knows the significance of the vast congregations 
that are sometimes seen, and who can tell us if there is any truth at all in the alleged "trials" of individuals who have defied the conventions of the community? It is interesting to know that the rook is a partial migrant, for there is a great ebb and flow every autumn and spring, and this may be connected with the flitting from the rookery to the roosting-place that we see in September. There may be far over a thousand nests in a rookery and the same site may be used for more than a century; and it is very interesting to have statistics such as Mr. Hugh S. Gladstone has given for Dumfriesshire, showing how old rookeries have waned and young colonies have grown, or to see in the inclosed rookeries of towns the evidence of an almost forgotten urbanization of the country. But the central interest is in the rook's reaching forward to a communal life with certain conventions, and to the crowded nests in which we see the beginning of a continuous social heritage of objectively enregistered traditions. 


\section{VI \\ CUCKOO PUZZLES}

$H^{R O M}$ various places we hear rumors that the number of birds that have come this year (1916) as summer visitors is below the normal, and, considering the atmospheric and other disturbances which the war has involved, we should not be surprised if it were true. But no one who had the good fortune to be near Dalmally and Loch Awe at the end of May could have failed to be impressed with the extraordinary abundance of cuckoos. Whatever was true of other summer visitors, the cuckoos, at any rate, were present in full force. They seemed to be everywhere-on the hedges by the wayside, among the birch bushes, on poplar trees (whose belated buds were just opening into amber-colored foliage), and on the telegraph wires going over the moor to Inveraray. The males were shouting excitedly all day long-recalling Lyly's "jolly cuckoos." We listened to him at five in the morning telling "his name to all the hills," and he continued to call far into the night. In the midst of torrents of rain we heard the "wandering voice," "at once far off and near"; and all through a storm, when the thunder rolled in solemn echoes from mountain to mountain all 
round Ben Lui, we heard the irrepressible dissyllabic and trisyllabic call, "Cuck-oo" and "Cuckcuck-oo." One fellow seemed to call thirteen times in succession, unless an echo or a rival falsified our counting; and every now and then we heard the female's curious "water-bubbling" laugh (she is not known to say "Cuck-oo"), upon which there were loud answering calls, and we sav a rush of two or three males, which was probably followed by a scrimmage. It is not quite certain that the laughing sound is confined to the female. It must not be confused with a remarkable noise often made by the male before the utterance of "cuck-cuck-oo." Mr. Kirkman compares it to "the noise that would be made by a person with a rasping cough trying not to laugh, but with indifferent success."

One of the many cuckoo puzzles was repeatedly before us on our week-end holiday, that a little bird (like a hedge-sparrow is all that we can truthfully say) often shadowed the cuckoo on its flight, and sometimes flew at it aggressively. This was seen with great clearness when the cuckoo and the little bird both alighted on the telegraph wires. After a brief pause the shadower would fly up in the cuckoo's face-a pygmy against a giant-whereupon the "blessed bird" of the poets would change its perch. The question which the often-repeated scene raised was whether the little bird was a resentful parent in whose nest the cuckoo had been playing its well-known trick. Or was it in line with that mobbing of a cuckoo by a crowd of little 
birds which we have seen elsewhere, which is often attributed to their mistaking the cuckoo for a hawk? There remains something puzzling here.

Wordsworth called the cuckoo a "mystery," and its behavior certainly presents many puzzles. The central one is the mother's evasion of brooding. As is well known, she usually lays her egg on the ground; takes it in her beak (sometimes under her tongue), and flies with it to the previously-selected nest of another bird. Sometimes when the nest is suitable she lays her egg directly in it, but this is often impossible. All is done quickly, cautiously, surreptitiously. There is considerable evidence that each cuckoo keeps as a rule to one kind of nest, and although over a hundred different kinds of foster-parents are on record, the list of favorites is not very long. It includes Hedge-Sparrow, Pied Wagtail, Titlark, Tree Pipit, Robin, Reed Wren, Warblers, Shrikes, and so forth. Unless some big mistake is made the foster-parents incubate the intruded egg, and rear the young cuckoo, who sees to it that they are not distracted by any rival claimants. The parent cuckoos are not known to take any interest in their progeny, and they leave our shores for the South a month or six weeks before the young birds are able to travel. The "parasitism" works well, and in the Common Cuckoo there is no exception to it. What light can be shed on the puzzle?

There are three considerations that make the evasion of brooding less perplexing than it appears 
at first sight. (I) To begin with, it is not an isolated phenomenon. It occurs in many other cuckoos and in the quite unrelated Cow-Birds. Some kinds of Old World Cuckoo follow the usual routine of nesting and brooding; the American Black-Billed Cuckoo, though usually a normal nesting and brooding parent, occasionally puts an egg in the nest of another bird; at least one species of Oriental Cuckoo is parasitic in one part of the country and nests in another; and there are many instances of diverse kinds of birds casually laying in the nests of their neighbors. Thus the cuckoo's evasion of the normal parental duties is not an isolated phenomenon, and it is also instructive to remember that the parasitic instinct is not always perfect. Many cases are known of a cuckoo's egg in an altogether unsuitable nest, for instance, in that of a bird which does not feed its young on insects. (2) A second consideration is that the mothercuckoo's behavior is congruent with some other peculiarities in the bird's constitution and ways. Thus there are far more males than females (sometimes perhaps five to one), and polyandry is the natural result, as has happened also with the CowBirds. And while it is probably going too far to call the polyandry the cause of the parasitism, it will tend to a slackening of parental ties, and in any case the parasitism is adapted to the polyandry. Similarly, the great fertility of the cuckoo (sometimes credited with a score of eggs, though a dozen is probably nearer the truth) is as likely to have 
been envolved in adaptation to the risks of the parasitic habit as to have been the cause of it. Very significant, however, is the interrupted egg-laying, for it appears that the mother lays five to seven on alternate days, and then stops, resuming after a short interval with a second lot of four or five. This would not fit in well with personal incubation, but it is congruent with the parasitic habit. Again, since the adult cuckoos feed very largely on hairy caterpillars, which become scarce after midsummer, there is an economic reason for the early migration and for leaving the care of the young to others. (3) Probably, however, we get most light on the problem when we adopt Professor F. H. Herrick's suggestion that the loss of the nesting instinct is due to an irregularity in the rhythm of the life-cycle -a formula which covers many a variation among animals. A constitutional change of deep germinal origin leads to the suppression of one chapter and the lengthening out of another, and just as one kind of bird may take to building supernumerary nests, another may take to skipping nest-building altogether. A lack of attunement between egglaying and nest-making is casual in many birds; it has become established in cuckoos because it was congruent with some other peculiarities of constitution and habit, and because it was found to work well. ${ }^{1}$

Another great puzzle concerns the cuckoo's eggs.

${ }^{1}$ See J. Arthur Thomson, The Wonder of Life (Melrose, London, 1914), p. 315. 
They are adapted to their curious history in being relatively small (though with considerable variability in size) and in having thick resistant shells, but still more strikingly in being, in many cases, like facsimiles of the eggs of the selected foster-parent. The fine "Fenton Collection" of birds' eggs in the University of Aberdeen has over four hundred cuckoo's eggs in the clutches of over fifty different kinds of foster-parents, and the two immediate impressions that one gets are, first, that the cuckoo's egg is often a perfect copy of those of the fosterparents; and, second, that it is often obtrusively conspicuous. Now it seems to be practically certain that the same cuckoo lays the same type of egg consistently, and it is probable that Professor Newton's theory is right, that having a blue egg, for instance, may be hereditary in a given lineage, and that there may also be in the same lineage a hereditary predisposition to put the egg in a Redstart's blue clutch. If the cuckoo is hurried or flurried, it may put the egg in a clutch with which it is inharmonious, and as this often succeeds perfectly well, it seems likely that some kinds of birds are much less sensitive than others to the presence of an intruded egg. Thus it is very rarely that a blue Cuckoo's egg is found in the blue clutch of the HedgeSparrow, and there is no "mimicry" between a Cuckoo's egg and a Wren's.

Another of the major cuckoo-puzzles has to do with the behavior of the young bird in the nest. What Jenner observed so carefully in $\mathrm{I} 788$, several 
naturalists have confirmed, that the blind and naked young cuckoo manages to get its body underneath an egg or a nestling, and by moving convulsively backwards, ousts it from the nest. It is a prodigious effort for a puny infant, and is followed by great exhaustion. After a rest, however, the eviction may be repeated if necessary. A short time ago the French ornithologist Raspail, in a paper read before the Zoological Society of France, gave expression once again to the skepticism which "Jenner's legend" has often aroused. Pouncing upon some faked photographs of the alleged eviction, Raspail upbraided naturalists with their credulity, and maintained that for six days after hatching it is a physical impossibility for the young cuckoo to push anything whatever outside the nest. What happens, according to Raspail, is that the mother cuckoo keeps an eye on the child which she has put out to nurse, and makes room for it in the nest by picking out the eggs or the young birds. It is admitted that a cuckoo in depositing its egg in a nest may occasionally puncture, or swallow, or remove one or more of the others; but, circumstantial as Raspail's picture is, we adhere to what Newton said twenty years ago: "Of the assertion that the cuckoo herself takes any interest in the future welfare of the egg she has foisted on her victim, or of its product, there is no evidence worth a moment's attention." It may sometimes happen that the foster-parents remove a broken egg or a nestling which the young cuckoo has mechanically 
smothered, but there is no doubt as to the general accuracy of Jenner's description and Mrs. Blackburn's drawing - the young cuckoo clears the nest by force. It is a mistake, however, to call it "criminal" or "murderer," for it does not know what it is doing. It has an instinctive capacity for eviction, and that has in all likelihood arisen as an elaboration and concatenation of certain peculiarities which are not very mysterious. Just as there are children who cannot bear to be touched, so the young cuckoo is hyper-sensitive to pressure on particular parts of the body, such as the sides. To certain pressures, inevitable in a nest which is too small for it, it responds by throwing itself backwards or by convulsive hitching movements of legs and arms. The flabby infant becomes strong with excitement, and performs feats of strength which seem scarcely credible. In any, case it gets the nest to itself, and its foster-parents seem to be quite proud of their unusually large baby, whose appetite keeps them very busy. 


\section{VII}

\section{THE FROG'S YEAR}

QPEAKING of our British frog, Rana tempo$\$$ raria, Dr. Gadow writes: "Next to Man there is no animal which has been studied so minutely, and has had so many primers and text-books written on it, as this frog. In spite of all this it is very little understood." Perhaps there may be some interest, therefore, in following its familiar lifecycle round the year. In Scotland it is usually in March that the frogs leave their winter-quarters and betake themselves from near or far to standing or slowly flowing water. The winter-quarters are described by Gadow in the Cambridge Natural History as "mostly holes in the ground, under moss, or in the mud," and Mr. O. H. Latter, in his Natural History of some Common Animals, speaks of our frogs as hibernating "some in holes and drain-pipes, others in or on the mud at the bottom of ponds." In his Ray Society monograph Dr. Boulenger says that "many males hibernate under water." It seems, then, that the grass-frog's habits vary considerably in different parts of its very wide range, and that some of them pass the winter in sheltered recesses far from the water. It should be noted that the grass-frog's near relative, the common 
edible frog or water-frog, Rana esculenta, habitually spends its winter in the mud of the pond, while in some other species the females hide during winter under moss, among leaves, and the like, while the males take to the moist mud. The internal economy of the winter torpor (perhaps the word hibernation is best kept for mammalian winter-sleepers) is of great interest. The fire of life burns low; no food is taken; a minimum of energy is expended; the reserves stored in the liver and in the "fatty bodies" are slowly used up; the respiration sinks back to a primitive mode-by means of the blood-vessels spread out in the skin.

None the worse for their long fast, the frogs bestir themselves as the winter disappears, and pair in the pools, often in very unsuitable places where the spawn is soon left stranded. The males call to their mates, and their croaking capacities (due to vocal cords in the larynx) are enhanced by the presence of two internal resonating sacs which lie at the posterior corners of the mouth and bulge outwards when inflated. These sacs are not developed in the females, who give voice much more rarely, and certainly do not respond vocally to the males' serenading. In the calls of different species of frog there is a striking individuality, and we cannot hear even the dull "grook, grook" of the grass-frog in the early spring without a thrill deeper than the cuckoo's wandering voice gives us later on. For, apart from the instrumental music of insects, the first voice in the evolution of animals to 
break the silence of Nature was that of Amphibians. The primary function of the voice was probably as a sex call, and that is its almost exclusive use in frogs. After the breeding season is over, the male grassfrog is almost as taciturn as the female. It is surely suggestive to think of the secondary employment of the voice in higher vertebrates in protecting and fostering the young, in expressing pain and pleasure, in communicating social news. As Professor Holmes notes in his interesting Studies in Animal Behaviour (I916): "The evolution of the voice in vertebrates doubtless influenced in a marked degree the evolution of the sense of hearing. It is not improbable, therefore, that the evolution of the voice, with all its tremendous consequences in regard to the evolution of mind, is an outgrowth of the differentiation of sex."

In this connection it is worth noticing that although frogs have poor brains, and are of course limited by their "cold-bloodedness," which makes their changeful body-temperature approximate to that of their immediate surroundings, they are pro. foundly affected at the sex season. The pairing and egg-laying may occur while there are still lumps of ice in the watcr, and before the creatures have broken their fast! The male has not only his resonating sacs, but a curiously swollen and hardened tetrapartite pad on his first finger, which he uses in violently embracing his mate. His whole skin changes considerably, and often shows a beautiful bluish sheen. The character of the 
female's skin also changes, and she puts on here and there an adornment of pinhead-like pearls of a white or pale-reddish color. In some cases the pairing is fatal to the females; in some cases the grass-frogs burrow into the mud after the spawning is over, and rest for about a fortnight before they leave for the summer-quarters.

The globes of jelly surrounding the frog's ova (one female may lay two thousand) correspond to the white of egg in a hen's egg, and serve many useful purposes. To begin with, the masses of spawn sink or tend to sink to the floor of the pool; but the spheres of jelly swell rapidly, some bubbles of gas (probably oxygen from adjacent submerged plants) help to buoy them up, and the clumps rise to the surface. The spheres of jelly form elastic cushions round the developing eggs; their unpalatability and slipperiness save the embryos from their enemies; they lessen the risks of drought; perhaps each crystal globe acts like a little glass house. In the interstices between the spheres there are often minute green Algæ which give off oxygen in the sunlight and thus have a useful aerating function. There is also a micro-fauna of frog's spawn, and some of the associated little creatures are of service in loosening the jelly when the larvæ are ready to escape. The dark pigment in the upper hemisphere of the egg seems of use in absorbing heat-rays, and in ordinary cases the larvæ begin to move about in the jelly some three weeks after 
their life began-that is, after the eggs at the moment of being laid were likewise fertilized.

Peculiar half-finished little creatures the newlyhatched larvæ are-mouthless, limbless, blind, covered with microscopic cilia, with just the beginnings of a first set of gills. They attach themselves by a horseshoe-shaped cement-organ to water weed, and subsist for some time on a legacy of yolk. It is an often-told story how these newlyhatched larvæ develop into true tadpoles, with open mouth, gill-clefts, and a second set of gills; how the limbs bud out; how the lungs develop and the two-month-old pollywogs learn to use them, taking gulps of air at the surface; how the circulation changes from a piscine to an amphibian type; and how after nearly three months have passed there is a striking metamorphosis, the outcome of which is a tiny frog. The substance of the tail is broken up, and dissolved as if a pathological process had become normalized; the amœboid phagocytes which play such an important rôle in inflammation have their share in changing the tadpole into a frog, now acting as sappers and miners, and again as transporting agents. The mouth changes its character entirely; the tongue, hitherto small, increases notably; the eyes, hitherto beneath the skin, reach the surface at last. It is time for the young frog to get ashore, else it will drown. It has been shown experimentally that not even the common waterfrog can live under water for more than ten minutes, 
except, of course, when in the torpid state into which they sink in winter, when the reduction of vitality minimizes the demand for oxygen.

There is much in the familiar sequence of events that is extraordinarily interesting, such as the recapitulation of racial evolution on the one hand and the specificity on the other. Thus there is no doubt that the young tadpole has a two-chambered heart like that of most fishes and a piscine type of circulation. This reads like recapitulation. Yet the tadpole's two sets of gills are quite different from those of ordinary fishes, and its skin is an amphibian's skin from first to last. This is specificity. There is a pretty point in regard to the tongue, which is at first non-mobile, just as is the case in fishes. Gradually muscle-fibers increase in the tadpole's tongue, and the foundations are laid of the highly developed musculature that enables the frog to shoot out its tongue in a somersault on the unwary fly. Another general fact of instructive value is the succession of varied solutions of the same fundamental problems. The sequence of diverse modes of respiration is remarkable. The newly-hatched larva breathes cutaneously; then three pairs of so-called external gills develop; then the mouth is indimpled and gill-clefts open out from the pharynx to the exterior; then a gillchamber is formed and a second set of gills replaces the first; then gills and lungs are used at the same time, just as in Dipnoan mud-fishes ; finally the small fully-formed frog is a lung-breather, with its skin. 
to fall back on if necessary. The changes in diet are equally striking.

But while the elusive tadpoles have been undergoing development in the relatively safe conditions of aquatic life, their parents have been living dangerously on land. In April or earlier the old frogs pass from the pond or pool to the meadows, woods, and fields, where they hunt for insects, slugs, worms, and other small fry, which must be moving to excite interest. The adults are followed in June or July by the froglings of the year, which often migrate from the water-pools in huge numbers. Their sudden appearance has formed part of the basis of stories of frog-showers, and we need not smile too broadly who still speak of it "raining cats and dogs." The crowd of small frogs, each well under half an inch in length-much shorter than the tadpole-is occasionally so thick that when we meet them crossing a road we find it difficult to pass without treading on them.

In the fields they indulge their insectivorous appetite and grow-but not very quickly. Every now and then they molt-that is to say, the outermost layer of the epidermis, often much the worse for wear, is split up along the mid-line of the back and slipped off. It seems to be good form that the frog should tuck its cast slough into its mouth, setting a fine example of economy. In spite of their adjustable protective coloration, which often gives them a garment of invisibility against a background of either brown earth or green grass, our 
frogs fall victim to the appetite of many enemies, such as birds of prey, stoats, and grass-snakes, so that only a fraction of the young migrants is left to make the return journey in late autumn. They are then about three-quarters of an inch long. As the grass-frog does not become mature for three years, it is likely that some of the youngsters winter in suitable quarters far afield. But Dr. Hempelmann, the author of a fine recent (1908) monograph on the frog, says of the species we have been discussing that the adults usually seek out the water again in autumn and spend about four months of winter buried in the mud thereof. Whatever be the exact truth about the winter-quarters, the frog's year is eventful indeed. How many years are granted it we do not know. 


\section{VIII}

\section{THE EDUCABILITY OF A SNAIL}

T T has been well established that a common 1 garden-snail can find its way home over difficult country from a distance of six yards or more. Of one that liabitually spent the day in a hole in a garden wall, about four feet from the ground, it is recorded that for months it utilized as a nocturnal ladder a piece of wood sloping from a bed of herbs to near the hole. Darwin mentions in The Descent of Man the case of two Roman snails, one sickly and the other vigorous, which were placed in an ill-provided garden. The vigorous one went over the wall into the next garden, where food was abundant. It was absent for tiventy-four hours, but when suspicion was growing strong that it had deserted its companion, it returned, and after a short time both disappeared over the wall. That the explorer was able to tell the invalid of the El Dorado over the steep mountains is very improbable, but the return to the starting-point is quite in line with other observations. It is likely enough that the scent of the slimy trail may assist in the way-finding, though it does not seem certain where the sense of smell has its seat in the common snail. But apart from evidence of "homing" 
and a few instances of profiting by experience (e.g. the effective behavior of water-snails dropped into an aquarium in which they had previously lived), there has hitherto been little basis for an answer to the question: "Can a snail learn?" But a satisfactory answer has now rewarded a series of exceedingly careful experiments made by Miss Elizabeth Lockwood Thompson (Behaviour Monographs, vol. iii, No. 3, I9I7, Cambridge, Mass.), and it is encouraging to learn that the answer is in the affirmative. Even a worm will turn; even a snail will learn. Who shall set limits to education?

Miss Thompson studied the learning process in a common water-snail, Physa gyrina by name, which is wont to glide about in ponds, mouth and creeping sole upwards, suspended to the surface film. The method of the research was a distinctly ingenious modification of a well-known experiment associated with the name of the famous Russian physiologist, Ivan Petrovich Pavlov. A dog's mouth waters at the sight or smell of food, and it is possible to measure the quantity and quality of the secretion. With the primary stimulus of food Pavlov associated some sound or color, and after a time the dog mastered or registered the association so thoroughly that the sound or color served of itself to evoke the mouth-watering. The shadow, so to speak, worked like the substance-somewhat in the same way as the sight of a menu-card may, within limits, serve as an appetizer. Miss Thompson observed that when the immediate neighborhood of the 
snail's mouth was touched with a little piece of food, such as lettuce, there followed a numberabout four was common-of rapid mouth-movements, opening and closing, in fact. These obviously correspond, in the logic of the experiment, to the mouth-watering of Pavlov's dog.

The next step was to find a practicable secondary stimulus, and that used was pressure on the snail's foot or creeping sole with a clean glass rod. This does not normally evoke any mouth-movement, except in rare cases, which are readily explained. The next step was to apply simultaneously the two stimulations, the touch of food near the mouth and the pressure of the glass rod on the foot. To this for a time no answer at all was given. It was not till the snails had been tried sixty to one hundred and ten times that they began to answer, but after the Rubicon was crossed they answered back all the rest of the total of two hundred and fifty trials. It was noteworthy, however, that the number of mouth-movements in a single response did not reach so high an average as was exhibited when the food stimulus was used by itself. The snails that gave the normal answer-back to the two stimuli applied simultaneously were regarded as "trained," and were ready for the next and crucial step in the experiment. Forty-eight hours after the completion of their training the snails were tried with the foot-pressure stimulus by itself. The dux of the class gave the proper mouth-moving answer the first seven trials right away; two other answers 
were given ninety-six hours after the end of the training. Other members of the class behaved in a similar way, but beyond the limit of ninety-six hours no answer could be wrung out of any of them. There was a sudden and final declinature to answer, which further experimentation showed to have no necessary connection with fatigue.

In some of the many sets of experiments, the punctilious carefulness of which deserves high praise, there was an interesting waning in the number of mouth-movements in any one answer. Following a maximum number of mouth-movements in a response towards the middle of the series of trials, the number gradually diminished to the end of the series. This indicated that the snails were becoming adapted to a stimulus which was not being followed by any reward. But the general result stands out clearly, and considering the humble creatures involved, is of very considerable interest. Snails which gave no mouth response to pressure on the foot were so affected by the simultaneous application of pressure to the foot and food to the mouth that they then gave the mouth answer to pressure on the foot. The effect of training with the simultaneous stimuli persisted for ninety-six hours after the training stopped. The snail learned its lesson, but the registration of experience, memory in psychological language, was shortlived.

Those who have some acquaintance with freshwater snails may be inclined to think that Miss Thompson's pupils were extraordinarily well be- 
haved. For what captured specimens very generally do on the slightest provocation-even jarring the aquarium a little-is to expel the air from their breathing chamber, retract into their shell, and drop to the bottom, where they may sulk for an hour. Realizing that this nervousness would make experimenting impossible, Miss Thompson began by "taming" her captives. They were taken in the hand at intervals and moved about under water; they were held till they protruded from the shell; they were abundantly handled, till they became so accustomed to it that they could be touched by the observer, or moved from one dish to another, without retracting their body or expelling the air from their lung. This "taming" is a further evidence of adaptability.

Very interesting data as to the educability of animals have been obtained by using simple labyrinths in which the creatures are placed at repeated intervals to see whether they learn to get out more quickly in the course of experience. It has been found useful in many cases to reward, say with food, a rapidly successful solution of the labyrinth, and to punish, say with a slight electric shock, the taking of the wrong road. Most of these experiments have been made with animals of high degree like cats and mice; Miss Thompson has spent much time and ingenuity in inquiring whether the labyrinth experiment can be adjusted so as to apply to freshwater snails. In one form of the experiment a $\mathrm{Y}$-shaped cylindrical glass tube was anchored 
to the floor of the aquarium. One arm was made rough internally, and at its upper end the snail received an electric shock, of which the roughness was meant to be the "warning." The smooth arm of the tube led to the surface of the water, where fresh air is obtained-sufficient reward in itself. The experiment consisted in pressing the air from the snail's lung and then placing it at the base of the so-called labyrinth. It is of value to the snail to get its lung filled as soon as possible; this is attained by creeping up the smooth arm, it is missed by creeping up the rough one; and the failure is emphasized by a mild punishment, the slight electric shock. But the result of the pretty experiment was to show a complete incapacity to profit by experience to the extent of solving the problem. The percentage of error did not diminish as the series of trials lengthened; indeed, things sometimes got worse instead of better.

In one interesting set of experiments a power of forming associations was displayed, but it was not, so to speak, followed up. Both arms were smooth, but the wrong road had as its warning notice-board an irritating hair which was made to touch the snail's horns and the back of its head. Immediately on the heels of the warning, if the snail persisted on its wrong course, came the punishment of a shock. Now, in 15.6 per cent. out of a total of nine hundred and thirty trials, the snails changed their course from the wrong to the right path after contact with the warning stimulus, but 
before the shock or punishment was received. This looked like, profiting by experience, but the snails showed no ability to utilize this in the further step of solving the labyrinth. Selective ability is apparently lacking. The interest of Miss Thompson's admirably conducted investigation is partly in its ingenious methods, and partly in its demonstration of the educability of a very unpromising subject. Here we are on the threshold of a quality that especially marks brains not loaded with ready-made capacities of instinctive behavior, the quality which Sir Ray Lankester has called educability, the quality of being able to learn. 


\section{THE CULT OF SHELLS}

TO children and to those who remain young I in eye, to artists and to unsophisticated persons generally, shells always make a strong appeal -and who can wonder? For shells have lines that flow, and shapes that sing, and colors that make melody. Each is the constructive work of the lifetime of a very intricate, yet harmoniously unified, creature; each is an architectural achievement that has stood the test of time for ages. Every mollusk expresses itself in its house (in a way man rarely does in his); and it has often an interesting personal way of registering in its shell some of the crises of its life, just as a tree records in its rings a summer of great drought or an autumn of very early frost. There is a sheer sensory delight in looking at a box of different kinds of cowries, cones, or olivas; there is a higher perceptual admiration in studying the well-adapted edifices built by architects whose designs are dreams rather than thoughts; there is an even subtler glow in sharing vicariously in that triumph of life over materials which many shells, like the Nautiloids, so well illustrate; but, besides these factors, may there not be in our delight over shells some echo 
of the impact which they made long ago on the mental framework of our ancestors? The child holds the shell to its ear, and listens to the supposed reverberation of the sea. What it hears is the sympathetic resonance of vibrations selected by the shell from the outside aerial turmoil, though some say a little is due to the internal vibrations of pulsing blood-vessel and tensely-strung muscle. But we wonder whether there may not be in the familiar childish experience some echoing recapitulation of a very old, very widespread, racial custom. For the cult of shells goes back to remote antiquity, and for millennia simple peoples listened to the voice of God in the sea-snail's shell.

Of the great interest of shells to students of human history we have had a recent revelation in Mr. Wilfrid Jackson's learned work on Shells as Evidence of the Migrations of Early Culture (I9I7), one of the ethnological publications of the University of Manchester. To this memoir Professor Elliot Smith contributes a luminous introductory essay, which helps us to understand the grip which shells took of human nature in the days of its impressionable youth. A new light is also thrown, as he says, on the curiously logical sequence of Father O'Flynn's intellectual achievements-

Down from mythology into thayology, Troth! and conchology, if he'd the call.

In many cases, as it seems to us, where living creatures or their products have strongly gripped mankind, there have been three factors at work- 
practical, æsthetic, and imaginative. This is surely true of shells. Throughout the greater part of the world simple peoples have used various shellfish (an abhorrent word to the zoologist) for food; and this, of course, continues, whether in oysters, which Huxley likened to "gustatory flashes of summer lightning," or, at the other pole of expenditure, in winkles, which require no apology. And apart from edibility and the use of mollusks as bait, many shells have proved of practical service to man as instruments or parts of instruments. Secondly, the decorative or emotion-exciting value of shells has been appreciated all over the world, the waistband of cowries and the necklace of pearls having the same merit of great beauty, enhanced in both cases, no doubt, by monetary and other associations. And, thirdly, it seems quite certain that infectious imaginative suggestions, perhaps rather fanciful and arbitrary to start with, have given certain shells psychological value as symbols, charms, and amulets. We venture to think that some anthropologists who have emphasized the symbolism of certain shells, notably cowries, have tended to underestimate the associated practical and sensory values. We fancy that the wide diffusion of a recognition of the symbolic significance of certain shells was partly due to their correlated beauty and usefulness. In any case, the three factors must have co-operated, as some examples will show.

One of the many undated human inventions was that of the shell-trumpet. It may have been 
suggested 'by listening to the shell-murmur. For here is a conch with a hole at the top or towards the top; it will not sing as the others do; let some breath be blown into it-for breath spells lifeand the strong-lunged youth had his surprise! In response to his pulmonary blast there came forth a trumpet-call-resonant, vibratory, wailing, terrific -like the voice of the wind-god. It is even now an instructive experience to get a strong-lunged expert to blow a first-class shell-trumpet in the quiet of an academic museum after hours. A forceful, insurgent, fog-horn call, with a volume that makes one a little ashamed, with cadences that startle-and how all the "curiosities" from Ceylon and Malay, from California and Madagascar, seem to reverberate! For it is an old, old story. The important fact was the vast effectiveness of the shell-trumpet's voice, likewise the disproportion between effect and cause. So the Triton, or some other conch, was blown to summon men to the temple and to the battle; it was used for emotional effects (and for symbolic reasons) at marriages and initiations; and it was not perplexing to our forefathers that what was official and symbolic one day should be a fog-horn or a cattle-call the next. What served to scare off evil spirits would also serve to frighten thieves. The shell-trumpet was effective and it was also beautiful.

The Minoans of Crete were the first to manufacture the famous purple dye from sea-snails like Murex and Purpura; the Phœnicians followed and 
dipped their precious fabrics in the vats of Tyre and Sidon; the news of the glorious color spread; and masses of broken shells still betray to the archæologist the diffusion of the purple industry round the shores of the Mediterranean and the Red Sea and far beyond both. There was ancient purple-dyeing in Great Britain and Ireland, in Central America and Mexico, in Malay, China, and Japan. The process of extracting the dye was so peculiar and distinctive that probabilities are strongly in favor of the view, which Mr. Wilfrid Jackson supports, that the secret was carried from the Old World to the New by early Mediterranean seafarers. The snail's secretion went through curious changes-colorless, yellow, green, bluishbefore it flushed into the fine purple-red; and that added to beauty a suggestion of mystery. The final color hinted at blood, and this again at vitality. Multitudes of snails were required in order to yield a little dye, and this meant many adventurous cruises, and these often meant many lives. So costliness embellished beauty, and the glamour of purple grew. Only a few men dare don purple robes, only a few women dare use the purple cosmetic, only the admiral's ship or Cleopatra's could have purple sails, only sacred script could enjoy the purple glory.

Another æsthetic appeal came from pearls and mother-of-pearl, the beauty of which has never ceased to charm. To the æsthetic glamour of pearls was added the romantic touch of their mysterious origin, and it is interesting to find 
that a theory connecting them with dewdrops is geographically very widespread. From headquarters on the shores of the Red Sea, where fisheries were established long before the time of the Ptolemies, the appreciation of pearls spread far and wide, in the New World as well as in the Old. It is well known that pearls took precedence over all other gems among the Romans and "according to Suetonius, the great motive of Crsar's expedition into Britain in 55 B.C. was to obtain its pearls, which were so large that he used to try the weight of them by his hand." These were, of course, the productions of freshwater mussels. The modern zoologist knows that pearls are produced by the reaction of the mollusk's skin to some minute focus of irritation, which may be the microscopic larva of a tapeworm or fluke, or a blob of conchin (the organic foundation of the shell), or even an inorganic particle. This was, of course, unknown to the ancients, but it is interesting to find from remote antiquity the outcrop of various recipes for the artificial stimulation of pearl-production within the mollusk. With a different smack are the old tales that if pearls are sealed up for a time in a box along with a little rice they will be found to have multiplied. The originals will not be any the worse; only the ends of the rice-grains will show an appearance of having been nibbled at. Given beautiful, mysterious, costly things like pearls, we have no difficulty in understanding the halo of secondary virtues. Burnt 
to powder they effected wondrous cures; in the mouth of the dead they gave light to the soul; they became emblems of purity and constancy.

All over the world some use or other seems to have been made of cowrie shells, and in many cases at least there was a cowrie symbolism. Perforated cowries are found associated with the early CroMagnon men and with pre-dynastic burials in Egypt; and they were used as money in China more than seven centuries B.c. Now, cowries are very beautiful shells, they are also very handy for money, tokens, messages, eyes for mummies, dice, balloting, and so forth; but there are strong reasons for believing (with Mr. Wilfrid Jackson and Professor Elliot Smith) that the grip they have taken of mankind has owed a great part of its tenacity to sex-symbolism suggested to the many by the shell's shape, and to the few by the way the living animal, expanding itself in the shore-pool, seemed to be born, as it were, from within the shell. There was no manual of the common objects of the seashore in those days, and to the impressionable it was a queer thing to see a rampant, horned and hungry creature slowly divulge itself. Moreover, were not these big shells exposed only at the lowest tides, so that from Mandalay to Mexico they were somehow linked to the moon, and thus again to women? We cannot help fancying that some of the early observers, in days long before Aristotle's illuminating insight, must have seen hermit-crabs coming half out of whelk shells and jerking back 
again with a click, must have seen what seemed to be just the familiar slow-going shells moving quickly and even fighting. What a fine basis for a doctrine of a demon in the shell the hermit-crab's tenancy would afford! But in any case Aphrodite was one of the earliest of man's deities, and the cowrie (Cypræa) which brought her to Cyprus was her emblem. It was emphatically the woman's shell, helping towards marriage and towards birth. It brought good luck, it averted the evil eye, but primarily it was a symbol expressive of fertility and vitality, and had life-giving, life-saving powers. In connection with the custom of placing a cowrie in the mouth of the dead, Professor Elliot Smith makes a very interesting note: "The twofold significance of the cowrie-the belief in its vitalizing powers and its use in currency-led to a confusion between these two properties, and was responsible for the origin of a remarkable custom. The cowrie was placed in the mouth because it was supposed to be able to animate the dead; but when it came to have a new value as currency this practice lost its original significance, and the use of the shellor the actual metallic coin that superseded itfor this purpose was rationalized into the belief that it represented Charon's fare for ferrying the deceased to the other world." According to Professor Elliot Smith the whole of the complex shell cult sprang from a fanciful suggestiveness which led a group of primitive men to connect the cowrie with sex. 
Few civilized men or women see any conspicuous symbolism in the cowrie; a coal-tar product has taken the place of Tyrian purple; pearls are no longer calcined to make priceless pills; and much that has been has passed away for ever. On the other hand, pearls retain their charm; the voice of the shell-trumpet has not yet ceased; decorations of shells are still very common; and there are few children to whom a beauty-feast of shells appeals in vain. Probably, however, the most enduring results of the cult of shells have passed indistinguishably into the fabric of the human web of life -ive mean " the important part the search for shells has played in the diffusion of the elements of culture and in the upbuilding of civilization." 


\section{$\mathrm{X}$}

\section{THE FITNESS OF RIGHT WHALES}

H VERY age has had its giants; those of to-day 1 are the whales. For the Sperm Whale and the Right Whales may be fifty feet long, and there are others even larger. The two examples just mentioned suggest the familiar division of the mammalian order Cetacea into the Toothed Whales with functional teeth and the Baleen Whales with whalebone-two groups which, if they had a common ancestry at all, must have diverged very long ago, for they are now separated by a multitude of structural differences. Among the whalebone whales there are two (or perhaps three) called "Right" simply because they are the right sort for whalers to pursue, being more valuable, as regards baleen and blubber, than the Finbacks and Humpbacks and other kinds which also bear these precious products, but in less degree. The recent publication of an admirable monograph, Mr. Glover M. Allen's Whalebone Whales of New England (Boston, I9I6), has prompted us to attempt an appreciation of the Right Whales, of which the Black North Atlantic or Biscay Whale, Balcena glacialis, is now the leading representative.

First of all, what an extraordinary bundle of 
adaptations is a whale! Think of the torpedo-like shape, suited for cleaving the water; the shiny, frictionless, almost naked skin; the horizontally flattened tail-flukes, which serve as propellers; the transformation of the fore-limbs into paddlelike flippers, which are moved en bloc and are mainly used in balancing; the thick layer of blubber (an exaggeration of the subcutaneous fat found in most mammals), which retains the warmth of the body, compensating for the almost entire absence of hair, and also helps to make the whale's great bulk more buoyant, and by its elasticity to resist the great pressure involved in deep diving; the shortening of the neck and the welding of the vertebræ of that region; the superficial reduction of friction, illustrated in the absence of external ears; the dorsal position of the valved, automatically-closing blowhole or nostril (single in the adult toothed whales, strangely remaining in the primitive double condition in the more specialized baleen whales); the sponginess of most of the bones, making for buoyancy; the remarkable networks of blood-vessels, which probably help respiration during the prolonged submersion; the relatively huge chest-cavity and the spacious (though simple) lungs, which are hydrostatic as well as breathing organs; the usual reduction of the offspring to one at a time; and the special milk-reservoirs which give the baby a big mouth ful at a gulp. These are more or less obvious adaptations, but for one that is obvious there are ten that are subtle. There is, for example, the arrange- 
ment for shunting forward the spout-shaped glottis (the entrance to the windpipe) so as to project into the posterior opening of the nasal passage at the back of the mouth. Thus the Baleen Whale swimming with its huge mouth yawning, so as to catch myriads of small fry, is not itself drowned. It is interesting that a very similar adaptation is seen when the crocodile is drowning its prey, and when the young marsupial in its mother's pouch is having milk injected down its gullet.

The story goes that a Yankee visitor to the Zoo, after a prolonged scrutiny of the giraffe, turned away with the remark: "I don't believe it." If he had been able to give the same attention to his own New England Right Whale, he might well have said the same. Black in color, a Colossus 54 feet long, with a head occupying about a fourth of the whole, with a neck as short as the giraffe's is long (yet with the same number of vertebræ), with about 250 plates of black baleen hanging down from the roof of the mouth on each side, and sometimes reaching a length of 7 feet-what a quaint creature! The plates of whalebone illustrate one of Nature's evolutionary methods, making the new out of the old, for they are exaggerations and cornifications of the transverse palatal ridges to be seen on the roof of the mouth in many other mammals. How striking, again, is the apparently disturbed topography, the nostrils far back on the top of the head, the inconspicuous eye away down at the posterior corner of the mouth, 
the ear-hole a little below and behind the eye and not wider than a match. And there is that curious, worn, warty, callous cushion near the front end of the snout, which goes by the name of the bonnet.

The imagination is tickled by the sparse groups of hairs about the snout, jaws, and chin. They are probably the dwindled residue of an abundant primeval pellage, for some embryo cetaceans show numerous hair-rudiments on the anterior half of the body. It is possible, however, that the ancestral Cetaceans had, even more than hair, an armature of scales, which was lost when aquatic habits were acquired. Some porpoises still show traces of scales, and there are some cetaceans in which no vestige of hair has been found, even before birth. The hairs seen on the Right Whale are without hair-muscles or sebaceous glands, but it is apparently to some purpose that they linger, for they are extraordinarily well innervated, four hundred nerve-fibers sometimes going to a single hair! They illustrate the conservatism of evolutionary processes, holding fast that which is good, even if it be diverted to a new function. It may be, however, that tactility was the primary function of hairs; we see it highly developed in the whisker hairs of many mammals, like the cat, and less familiarly in various types, in strategically disposed tufts about the hands and feet. Very impressive are the deeply buried relics of a hip-girdle and thigh-bone, measuring in a typical specimen of a North Atlantic Right Whale 18 and 5 inches respectively. They show an 
interesting variability not uncommon in dwindling structures, and their long lingering may be partly due to the fact that they afford insertion to certain small muscles. In some unborn whales there are two small button-like projectionsexternal hind-limbs literally at a vanishing-point. Absolutely vestigial are the Right Whale's teeth, which never cut the gum and are absorbed before birth. Yet there is a first set and a second set-as in ourselves.

There is much that is interesting in the senseorgans. The eye is without the usual eye-cleaning third lid, its absence being compensated for by the continual washing; its practical absence in our own case is compensated for by the frequent movements of the upper eyelid. The smelling membrane is degenerate, and there are other olfactory deficiencies, intelligible enough in animals of terrestrial origin which have come to be habitually submerged. The outer ear passage is open to the water, and the drum is so fixed that it cannot vibrate; it is probable that the chief use of the whale's ear is in equilibration, and in making the animal aware of changes in the pressure of the water as it dives or rises. If sounds pass to the earossicles and the inner ear, it must be through the bones of the skull.

The Black Right Whale is not gregarious, but a pair may keep company for long, and they may be followed for over a year by their calf. The ordinary rate of swimming is leisurely, about four miles an 
hour; and the creature is fond of lying quietly on the surface, perhaps asleep. Mr. Allen quotes an old story of the Mayflower's encounter in Cape Cod Bay. "We saw daily great whales, of the best kind for oil and bone, come close aboard our ship, and in fair weather swim and play about us. There was once one, when the sun shone warm, came and lay above water, as if she had been dead, for a good while together, within half a musket shot of the ship; at which two were prepared to shoot, to see whether she would stir or no. He that gave fire first his musket flew in pieces, both stock and barrel; yet, thanks be to God, neither he nor any man else was hurt with it, though many were there about. But when the whale saw her time she gave a snuff, and away." The blowing or breathing-out of hot air occurs half a dozen or more times in rapid succession, and the "spout," consisting of watervapor condensed into drops, plus, it may be, a little spray carried up by the nose-opening blast, may rise to a height of fifteen feet. Since Aristotle did not think of a whale as a fish, Milton was not very happy with his "And at his gills draws in, and at his trunk spouts out, a sea." After a longer or shorter period of forceful breathing the whale dives (almost perpendicularly, so that the flukes are the last parts seen), and may remain under water for ten to twenty minutes. The Right Whale is a dainty feeder as far as quality goes, for it depends mainly on small crustaceans. These are engulfed in the yawning cavern of the mouth, strained 
on the frayed inner edges of the baleen plates, collected by the slow raising of the fat and flabby tongue, and then passed down into the narrow gullet. Whatever a Cachalot may have done, no Right Whale ever swallowed even a minor prophet.

No one has yet got on terms of intimacy with a Black Right Whale, but the general impression seems to be that it is a gentle creature, only taking the offensive when tormented. It may then break a boat with the impact of its bonnet or bumper. In illustration of its endurance $\mathrm{Mr}$. Allen quotes the case of a "sixty-barrel" Right Whale which was struck early in the morning off Nantucket, and, heading out to sea, towed a boat with six men in it for seven hours, and eventually got free. It took the men five hours' hard pulling to get home. Very little is known of the breeding habits, but the pairing seems to take place in early summer and the birth in January or February. The length of the newborn calf is about 20 feet. It is said to accompany its mother for at least a year, being weaned when between one and two years old. There is no doubt as to the parental attachment of the mother, for she will sacrifice herself in the attempt to rescue her offspring, or in the refusal to leave it even when dead. So far as is known, the North Atlantic Right Whale has no natural enemies, and they are not known to fight among themselves. It is a long-lived, dumb, peace-loving creature-too gentle to survive man's frightfulness for long. 
The particular whale we have discussed is probably not specifically distinguishable from the Black Right Whale of the South Atlantic, but it is quite different from the Greenland Whale or Bowhead, Balcena mysticetus, which used to be the object of the eager quest pursued by the whaling vessels that went north from Dundee, Aberdeen, Peterhead, and similar ports. But that is a story of the past, for the Greenland Whale is now a rarity. In the fascinating whale-room of the British Museum we have seen the enormous lower jaws of one of the largest of these magnificent creatures, which was killed in 1887 . It yielded 26 tons of oil and $26 \mathrm{cwt}$. of whalebone. This Greenland Whale is entirely Arctic; it is recorded as attaining a length of 70 feet; its head occupies a third of the body; its black color is relieved by white below the jaw, and there are various important structural differences between it and its non-Arctic relative. Dr. F. E. Beddard, a great authority on whales, tells us that the Greenland Whale is "an extremely timid beast." It has been remarked that "a bird alighting upon its back sometimes sets it off in great agitation and terror." But we do well to be cautious with psychological adjectives when speaking of whales. For what do we know of the "terror" of this marine Colossus, whose brain is of a very high order? The timidity is probably in part a function of the frequency of whalers. There is unanimity, however, in the theoretical admiration of the whale's parental solicitude. "It would do honor," 


\section{THE FITNESS OF RIGHT WHALES 79}

said Scoresby, "to the superior intelligence of human beings," who will nevertheless seek after blubber and baleen until the Right Whales have, alas! shared the fate of other giants and passed into the keeping of monographs and museums. 


\section{$\mathrm{XI}$}

\section{THE INTERNAL ECONOMY OF THE SEA}

TO one can forget the first sight of a big catcb 1 laid out for sale at one of our chief fishing ports. There are tons and even miles of fishes, recently representing enormous locomotor power in the sea, and soon to be transformed into likewise enormous, though reduced, power of muscle-work and brain-work on land. The sweepings go to feed cattle and to fertilize the ground, and the total supply is in such abundance that we stand wondering at its continuance from day to day, year in year out. What happens in the vast economy of the sea? Who are the producers, the consumers, and the middlemen? A well-known instance will illustrate our inquiry-namely, the demonstration, offered some years ago by Dr. E. J. Allen, the Director of the Marine Biological Station at Plymouth, that there is a close correlation between the sunshine records for May and the quantity of mackerel at Billingsgate. The rationale of this is instructive. Mr. G. E. Bullen showed that there is a correspondence between the catches of mackerel during May and the amount of the Copepod plankton (i.e. small Crustaceans of drifting habit) upon which the mackerel for the most part feed. Then 


\section{INTERNAL ECONOMY OF THE SEA 81}

Dr. W. J. Dakin showed that the Copepods, in turn, feed largely on the drifting plant-organisms of the surface waters, such as Diatoms, and on Infusorian-like animals called Peridinians. But the multiplication of these minute organisms depends in the main on the amount of sunshine. So that the more sunshine, the more mackerel. One incarnation follows another, Copepod after Diatom, Mackerel after Copepod, Man after Mackerel-an illustration of Liebig's luminous idea of the circulation of matter.

The producers of the wealth of the sea are the chlorophyll-possessing organisms, most of which are indubitable plants, though a few incline to the animal persuasion. Of the plants there are two great groups: (a) the minute Algæ of the superficial layers of the open sea (the Phyto-plankton), and $(b)$ the sea-grass, the larger seaweeds, and the attendant micro-flora, abounding in the shore area in the wide sense. Though many of the seaweeds have also brown or red pigment, all have chlorophyll. And by virtue of this-we do not know how - they are able to utilize the energy of the sunlight to build up the simple constituents of air and seawater into complex organic products which in turn form the food of animals. On this power of photosynthesis depends the whole economy of marine as of terrestrial life. It is very generally believed that the chief producers are the minute and simple Algæ of the open waters which form in certain areas which Sir John Murray used to call "floating 
meadows." On the Beagle voyage Darwin was impressed off the coast of South America with vast tracts of water discolored by the minute floating Algæ, the "sea-sawdust" of Captain Cook's sailors, and since the days of the Challenger information in regard to the Phyto-plankton has grown apace. It seems to be the food of many open-sea animals, such as small Crustaceans, which again are devoured by young fishes. The growth of the sea-meadows in spring is thus as important as the garment of green on the farmer's fields. Professor Herdman of Liverpool, a leading authority on the biology of the sea, cites the calculation that a Diatom "less than the head of a pin, dividing into two at the normal rate of five times in the day, would at the end of a month form a mass of living matter a million times as big as the sun. The destruction that keeps such a rate of reproduction in check must be equally astonishing." It should be noticed, however, that considerable evidence is accumulating in support of the view that the minute constituents of the Phyto-plankton are even more important in their death than in their life. For when they are killed by changes of temperature and the like, or when they reach the end of their natural tether, they add to the valuable organic detritus which remains in suspension in the water or sinks to the floor of the sea. To this accumulation of organic débris very important contributions are also made from the littoral belt of seaweed and sea-grass. Indeed, recent investigations by two 
Danish naturalists, Petersen and Jensen, show that the organic matter of the sea-floor in the sheltered waters of fjords and bays is mainly due not to the sinking down of the minute Plankton organisms, but to the detritus of the sea-grass (Zostera) and its associates in shallow water. This is of enormous practical importance, since it is in man's hands to cultivate, if need be, the littoral vegetation, and thus cast bread upon the waters, to be gathered again after many days. But aquiculture is not yet a pressing need.

As to a heresy started some years ago by Professor Pütter, that sea-water contains large quantities of dissolved organic matter-a sort of fundamental "stock" of the sea-soup-and that this accounts for the sustenance of many marine animals whose food supply has been confessedly difficult to discover, it cannot be said to have been confirmed by further investigation. In fact, recent work by Professor Benjamin Moore and others at Port Erin Biological Station is quite against it. The probability is that sufficient importance has not been attached to the nutritive rôle played by the organisms of the Divarf Plankton (Nanno-plankton), which abound beyond telling in the open sea, and are so extremely minute that they pass through the invisible pores of the finest silk cloth used in townetting. There is thus no reason to depart from the conclusion that the producers in the economy of the sea are the chlorophyll-possessing plants, both of high and low degree, and such small animal 
organisms as have stolen their secret of photosynthesis. But it is time to add the statement that a large proportion of the animals of the seafloor live on dead detritus, which is formed by contributions from three sources-the superficial Plankton, the fauna and flora of the shore, and what is borne down by rivers. We shall return to this in our next study.

The natural consumers of the wealth of the sea are the animals, but these are not all on the same platform. First, there are true carnivores, like most fishes, all cuttlefishes, many Gasteropods (like whelks), many crabs, most starfishes, and so on down to sea-anemones. Second, there are vegetarians, like periwinkles and limpets, on the shore, and some of the open-sea animals like the Copepod Crustaceans. Third, there is an enormous multitude depending mainly on crumbs or detritus. This classification is not, of course, to be taken too rigidly, for it will be readily understood that many a marine carnivore may also utilize carneous débris - just as a Golden Eagle, with a preference for fresh grouse, does not always hold carrion in disdain. Similarly, some marine vegetarians are not too scrupulous as to the constituents of the sea-soup they enjoy. The probability is that the distinction between carnivore and vegetarian is not so important as that between animals with and animals without hard prehensile and chewing mouth-parts. This, like Professor William James's division of mankind into tough-minded and tender-minded, goes very deep. 
We may speak of it as the distinction between the hard-mouthed and the soft-mouthed, and it is radical. But to follow it up would take us too far from our present theme.

The middlemen are Bacteria, which get involved in so many different ways in the business of life. Salt is well known to be antithetic to them, but it has not kept them out of the sea, where they have more than one important rôle to play. Thus some are putrefactive, breaking down the dead bodies of animals and plants, and the excreta of animals, reducing them to carbon-dioxide, ammonia, ammoniates, and the like, which may re-enter the field of life by forming food for Algæ. Microbes of this sort are for ever making a clean thing out of an unclean. But there are others which play a subtler part, by changing the ammoniacal nitrogen into nitrites, and others which carry on this work by completing the oxidation into nitrates. And as nitrites are more available for the nutrition of plants than are ammoniacal compounds, and as nitrates are more available than nitrites, we see, as they said of old time, how well this world is governed. It is not to be forgotten, however, that there are many denitrifying bacteria which work the wrong way by reducing nitrates to nitrites, nitrites to ammonia, and ammonia to free nitrogen. Professor Brandt has suggested as a reason for the remarkable fact that the cold Polar waters are richer in Plankton than tropical seas, that the higher temperature favors the action of denitrifying bacteria, which 
therefore flourish so abundantly that the supply of available nitrogenous food for the Phyto-plankton is greatly lessened. According to Sir John Murray and Professor Jacques Loeb, the reason is rather that low temperature slows the vital processes and increases the length of life, so that several generations of Plankton organisms are living at the same time in the colder waters. It is probable that both views are correct.

It is hardly necessary to say that the analogy of producers, consumers, and middlemen should not be pressed too hard. Thus it is quite useful to follow a recent investigator, Dr. Blegvad, in regarding the detritus-eating animals as producers in relation to the carnivores, just as fishes are producers in relation to the supreme carnivore Man. Bivalyes and other animals which feed at a low level on minute débris are making available to any creature that can eat them supplies of energy which would otherwise be wasted, Plaice in the Kattegat are very fond of lancelets, which subsist on detritus particles; so that in respect to the plaice the lancelet is a producer or a middleman. The main idea is that of the circulation of matter, or of what Sir John Murray, who did so much to make Oceanography a science, called "the never-ending cycle." The Algæ find nourishment mingled with the water that bathes them, and, using chlorophyll to "conjure with the sunbeams," they build up organic compounds from inorganic constituents. Vegetable proteins are thus formed, and when these are eaten 
by animals they are raised to a still higher incarnation as animal proteins. But when the plant or animal dies the complex organic substances are broken down through the agency of bacteria into simple constituents once more, and some of these being utilized by plants may enter again into the circle of life. Shakespeare, with his prescience, spoke of what might happen to the dust of Cæsar, but it was only a vague vision that he can have had of the long nutritive chains, with quaint sequences like those of "The House that Jack built," which connect Diatoms and débris with fishes and man. As Professor Herdman tells us, man eats the cod, which in turn may feed on the whiting, and that on the sprat, and the sprat feeds on Copepods, which again depend on Peridinians and Diatoms. Most of the nutritive chains bring us through Copepods to sea-grass and seaweeds, to Diatoms and débris. For so the world goes round, and such are the incarnations of the sea. 


\section{XII \\ SEA-MEADOWS}

4 XPLORERS of the sea have described " floating meadows," consisting of countless millions of minute or microscopic plants, extending for, perhaps, a hundred miles without interruption. These simple plants, and the minute single-celled animals often associated with them, afford food for Crustaceans and other small fry, which, in turn, are eaten in great numbers by dainty feeders like mackerel. A few fishes, such as sardines, feed in great part directly on unicellulars. There is no doubt that the minute inhabitants of the superficial waters are directly or indirectly of great importance as food for creatures of larger growth, such as mackerel and herring, which, in turn, mean much to man. Dissolved organic compounds, sometimes rising from the floor of the sea, sometimes produced near the surface, may be utilized by larger animals (to what extent we do not yet know), or may be reclaimed for utilization by the varied and often subtle agencies of bacteria. So much, in passing, for the surface population; but what of the foodsupply along the floor of the sea?

In answering this question it has been usual, as we have seen in the preceding study, to give promi- 
nence to the part played by the down-sinking of minute (Plankton) organisms killed or worn out at the surface, and there is no reason to disregard this factor. It is probably of fundamental importance for the immense areas which may be called more or less abyssal, for these, being far beyond the limit of illumination, cannot have any autochthonous plants able by photo-synthesis to build up complex carbon-compounds from simple constituents in the water. But in the relatively shallow illumined waters near shore the economy is different, and it seems that great importance must be ascribed to what may be called "sea-meadows,"-the dense growths of sea-grass (Zostera), a veritable flowering plant, and of attached seaweeds, large and small, from the great bladder-wracks and laminarians to the small tufts of the palatable "carrageen" or Irish moss. Without depreciating the rôle of the minute Plankton organisms which may sink down from the surface, we wish to state the case which Professor C. G. Joh. Petersen has recently presented in an interesting report (I9I8) to the Danish Board of Agriculture, which at any rate shifts the emphasis to the sea-meadows. It need hardly be said that Danish waters are much less heterogeneous than those around British shores.

In the relatively shallow Danish waters the seabottom consists of vast plains of sand, mud, or clay, with transitions between these; and almost everywhere except in the deepest and calmest hollows there are scattered stones of all sizes carrying a 
distinctive population of their own. From the shore to a depth of two or three fathoms are the meadows of the sea-grass, with true roots and flowers and very long ribbon-like leaves, familiar as a packing and stuffing material and as a covering for Italian flasks of wine or oil. Mixed with this Zostera are the seaweeds proper, attached but without true roots, enlivening the grass-green with beautiful reds, browns, and olives. Farther out the seaweed vegetation thins, until it disappears at a depth of about twenty-five fathoms. It is a crowded vegetative area, able to support a crowded animal life; the waving sea-grass is often as thick as the stems in a cornfield, and Professor Petersen notes that the total annual yield in Danish waters is over 8000 million kilograms of dry matter, about four times the quantity of hay produced in a year in Denmark. This suggests further utilization-the Zostera is already used for fodder, for paper-making, for making explosives, and in other ways-but sea-grass is a difficult harvest to reap, and perhaps its greatest value is the indirect one, that it forms a basal food supply for animals on which many food fishes mostly depend. For what Professor Petersen and his colleagues have discovered is that the surface of the mud (or clay farther from shore) is covered by a thin layer of detritus of very nutritive quality, and that this is mainly produced by fragments of sea-grass and littoral seaweeds, the downward sinking Plankton counting for little. Examination of the stomach contents of common non-predatory 
animals shows that the food consumed consists very largely of this valuable débris. Thus the main food of oysters and other bivalves is vegetable dust "which is found, either in suspension in the water, or deposited as the thin upper layer of the bottom itself, lifting and spreading at times in stormy weather, but only to be precipitated anew later on."

Some of Professor Petersen's statistics are very interesting. His valuation of the sea-meadows of Danish waters inside the Skaw shows a total of 24 million tons for the plants, 5 million tons for those animals that are "useless" both directly and indirectly, I million tons for the "useful" forms that furnish or may furnish food for fishes, and only some few thousands of tons ( 5 to 7000 ) for each of the short list of valuable food fishes, such as plaice and cod. Starfishes make up 25,000 tons, more than all the important food fishes lumped together, while crabs and Gastropods amount to no less than 50,000 tons. We see that food-fishes form only an insignificant part of the total stock of animal life in waters like the Kattegat. The reason is to be found in the relations that govern the circulation of matter or the metabolism of the sea. To make a pound of cod requires Io $1 \mathrm{~b}$. of whelk or buckie; to make a pound of buckie requires Io $\mathrm{lb}$. of worms; to make a pound of worm requires Io $\mathrm{lb}$. of vegetable matter, which may be given in the form of dust! So a pound of a carnivorous fish like a cod requires I000 $\mathrm{lb}$. of sea-grass. If there be fewer links in the House-that-Jack-built nutri- 
tive chain, the pound of flesh will be, so to speak, cheaper. Thus a pound of plaice is said to require to begin with only $100 \mathrm{lb}$. of vegetable material. But the basal fact is clear that just as all flesh is " grass," so sooner or later all fish is. "seaweed."

In spite of the old saying, Vitior alga,-_" More worthless than seaweed,"-these humble plants have many uses, e.g. in making mannite, mucilage, and manure. The nutritive value of seaweed is, indeed, an old story; the streets of Edinburgh used to resound with the shrill cry of the fishwives"Wha'll buy dulse and tangle?" but what science has shown is that the indirect importance is much greater than the direct.

It is plain, then, that fishes are far from being economical to produce. They are like a superstructure that requires a very broad and costly foundation. The quantity of humbler life that makes the food-fishes-almost wholly carnivorouspossible is enormous; and the estimate has to be increased when we remember that a great proportion of the weight of an animal which a fish devours may be quite useless-e.g. the water in its tissues and the shell of lime. Thus we are naturally led to Professor Petersen's important practical conclusion that the quantity of fishes which an area of sea can support is anything but unlimited. In some restricted bays, indeed, he found strong reasons for suspecting that the limit had been reached. That this limit is a generous one is an important fact for man, for the Danish fishermen took about 60,000 
tons of fishes off their coasts in 1915 , which is more than twice the total export of eggs from the country. And fishes have not to be fed in the same sense as poultry. The question arises, however, whether the system of interrelations established in the sea cannot be improved so as to yield a smaller number of useless and a larger number of useful animals. An interesting question indeed, but no naturalist who realizes the implications of "the web of life" will be in a hurry to do more than experiment on a small scale. The balance of nature is not to be tampered with impetuously.

Utilitarian considerations apart, the sea-meadows are of great scientific interest. In his Voyage of the "Beagle," Darwin was impressed by the Kelp (Macrocystis pyrifera) and its animal associates. He writes: "The number of living creatures of all orders whose existence intimately depends on the Kelp is wonderful. A great volume might be written describing the inhabitants of one of these beds of seaweed. . . I I can only compare these aquatic forests of the Southern Hemisphere with the terrestrial ones in the inter-tropical region. Yet if in any country a forest was destroyed, I do not believe nearly so many species of animals would perish as would here, from the destruction of the Kelp."

The succession of incarnations from sea-grass to fisherman gives one a vivid impression of the universal flux; there is a fascinating variety of animal-communities-Professor Petersen distinguishes eight distinctive associations, each with an economic 
régime of its own; the struggle for existence is intense; the life-saving adaptations and shifts for a living are endless; " passions there, laws, pursuits, tribes," as Walt Whitman said in his "World below the Brine." For it is to the region of the seameadows rather than to the deep sea, that most of that vivid picture applies:

The World below the brine,

Forests at the bottom of the sea-the branches and leaves,

Sea-lettuce, vast lichens, strange flowers and seeds-the thick tangle, the openings, and the pink turf,

Different colors, pale grey and green, purple, 'white, and gold-the play of light through the water,

Dumb swimmers there among the rocks-coral, gluten, grass, rushes-and the aliment of the swimmers,

Sluggish existences grazing there, suspended, or slowly crawling close to the bottom.

This and more also will be subscribed to by all who have spent a summer afternoon drifting here and there over the sea-meadows, peering into the crowded life below, enjoying the play of color, lifting now and again a leaf of sea-grass-sometimes 6 feet long-to discover how many small creatures were browsing there, or raising mare adventurously a stone from the bottom to see what is meant by an "epifauna," sometimes a dozen different kinds of creatures living together in moving equilibrium. "But what an endless task have I on hand to count the sea's abundant progeny, whose fruitful seede farre passeth those on land ... so fertile be the flouds in generation, so huge their numbers, and so numberlesse their nation." 


\section{Xìì}

\section{FRANKINCENSE AND MYRRH}

W

HEN we come in the sunshine upon a patch of mown grass with a good proportion of Sweet Vernal, we experience, with all normally constituted mankind, a great sensory satisfaction. The fragrance is delicate, complex, and restful; for the moment all is right with the world. But why it should be so, it is difficult to tell. The odoriferous substances in plants are usually ethereal oils and resins, by-products or end-products of certain vital chemical processes. Little is known of their physiological significance in the economy of the plant; most of them rank as waste-products. But should one of them turn out to be very attractive to the olfactory sense of welcome insect-visitors, such as bees, or very repellent to voracious enemies, such as snails, then it will tend to acquire survivalvalue, and, other things equal, to grow in strength. We have to think of all these new departures-for they must all have had their beginnings-as like tendrils probing the unknown. If they get no encouragement they come to little, except in so far as they are the necessary corollaries of indispensable antecedent processes; if they find a support they grow strong. Thus some of the 
odoriferous substances of plants are justified by their protective value, and others by their attractive value, while of many it must be simply admitted that their significance is internal and chemical, sometimes perhaps no more than that of the wasteproducts in a manufactory, and that their quality of olfactory stimulation has not been turned to any account. They are the ashes of the living fires, yet as we sniff the perfumed air in which quintillions of aromatic particles are hurrying past us, here from gorse and hawthorn, there from woodruff and sweet vernal grass, we cannot but ask whether this multitudinous aerial excretion may not have some physiological significance in the economy of creatures which are, as compared with animals, conspicuously without arrangements for getting rid of their waste products. May not this volatilization of the ethereal oils help to keep the floral fire from being smothered in its own ashes?

In this medley of odors, whiffs of brier rose and lady's bedstraw, honeyed clover and soporific myrrh, the idea that rings in the mind like a bell is Individuality, Specificity, Uniqueness. All flesh is not the same flesh, and each flower's fragrance is its own and no other's. Some five hundred different aromatic compounds have been distinguished, such as the aminoid in hawthorn, the benzoloids in mignonette and violets, the paraffinoids in geranium and rose, the turpenoids in orange and lavender, each group including many specifically different kinds, indices of the individuality 
of the chemical processes in each plant. Strangest of all are the indoloids in Aroids, Aristolochia, and Rafflesia, which attract carrion-loving flies and are said to arise from the breaking down of proteids. Besides the specificity of chemical composition and scent there are other individual peculiarities, for some plants have fragrant leaves, while in others the incense is made only by the petals; some, like the grass of Parnassus, are sweetscented only in the sunshine, while others, like the evening campion, wait for the night. The nauseating smell of the corn-spurrey is particularly strong after a summer shower.

The production of odoriferous substances is characteristic of flowering plants, but by no means confined to them; it is familiar, for instance, in the males of many butterflies and moths. Peculiarly transformed scales on the wings, or tufts of hairs on other parts of the body, exude an aromatic secretion, the secondary significance of which is that it appeals to the female insects. Some of the scents produced by male Lepidoptera are pleasant to the human olfactory sense, resembling musk, mint, vanilla, honey, and the like; others are suggestive of mice and bats. It is interesting to notice that in some cases, though glandular scales are abundantly present, we cannot smell anything, which probably means that the aromatic substances lie outside our range of olfactory stimulation, just as many rays of light lie beyond our range of vision. It may be recalled that the volatile 
poison of toads, known as phrynin, inflames the olfactory membrane if we sniff it, yet there is no smell. It is certain that the world is full of scents, as of sounds, to which, happily or unhappily, our senses are not attuned. There is experimental evidence of a highly specialized sense of smell in many insects, such as hive-bees, and its practical value to flower-visitors is obvious. According to a recent investigator, a drone bee has 2600 olfactory pores, and responds to a suddenly introduced fragrance, such as oil of thyme, in 2.9 seconds; a worker had 2200 pores, and responds in 3.4 seconds; and a queen has I800 pores, and responds in 4.9 . seconds.

Odoriferous substances are formed in many insects besides moths and butterflies, as every one knows in the case of cockroaches and bugs, and it is possible that they have primarily to do with wasteproducts, just as the white and yellow color of some butterflies is due to uric acid or derivatives thereof-a literal beauty for ashes. Secondarily, however, the scents of insects have come to have a significance in mating, and they are often confined to the males. They are comparable to the musky odors of musk-deer, musk-ox, and crocodile, and to other scents in many male mammals and in some male reptiles. The presence of scent-glands in many male bats is an obviously useful adaptation to crepuscular conditions; that there should be practically no development of the kind in birds is naturally correlated with their poor sense of smell. 
Where scent-glands occur in both sexes among mammals, they may contribute to a mutual sexappeal, or they may facilitate the recognition of kindred and of well-frequented roadways. In certain cases they may be protectively repellent: thus shrews are in some measure saved from cats by the odoriferous gland which runs along the side of their body. In the homing of many ants odoriferous particles serve as guide-posts, and the accuracy with which a dog tracks his master's footsteps is one of the marvels of everyday life. Of the chemistry of animal scents little is known, but in insects they include fatty acids, even salicylic acid, free iodine, and in a common millipede of greenhouses actually hydrocyanic acid-all of them holding out a promise to the investigator.

The sense of smell is nearest that of taste, and the two probably merge in some of the fishes. In smelling we are affected by minute particles which are dissolved on the moist surface of the olfactory membrane in our nostrils; in tasting we are affected by substances similarly dissolved on the taste papillæ of our tongue. We' can smell extremely dilute solutions which we cannot taste. Thus a very minute amount of material coming from a far-off object is sufficient to stimulate our sense of smell, but insufficient to affect taste. Therefore, as Professor Sherrington has put it, our olfactory organs are "distance-receptors," as compared with our gustatory organs. In both cases the stimulus is due to the chemical action of 
a foreign body, and the same is true of the general chemical sense, best known in fishes, which has its seat on various parts of the skin and detects diffusing substances.

It has been widely assumed that the general chemical sense represents the primitive irritability from which smell and taste have been evolved, but the work of Professor G. H. Parker points rather to the conclusion that " the most primitive of the chemical sense organs in the vertebrate is the olfactory organ, followed by that of the common chemical sense, from which the final organ in the series, the organ of taste, arose." It is certain that the olfactory nerve-cell, characteristic of backboned animals, such as is pleasantly stimulated when we detect from far inland the tang of the sea, closely resembles that of many humble backboneless animals, such as is stimulated when the sea-anemone in the aquarium stretches its tentacles towards the food which we have dropped in at a distant corner. There is no telling why the stimulation produced in us when we tread on the wild thyme is so very pleasant and why that produced by the corn-spurrey is so very unpleasant, the one flower is just as beautiful as the other; but it is possible that careful inquiry might carry us beyond the bare facts. Certain scents have a stimulating effect on the pulse, increasing our feeling of vitality, and similar scents which have no such physiological virtue may by association acquire vicarious merit. Similarly, some unpleasant natural odors, like that of hound's 
tongue and that of mice, may turn out to have an actual depressing effect, which may be emphasized by association if they call up the memories of the fatigue and stupefaction induced by organic particles in crowded rooms and filthy streets.

It is usually said that man's pleasure in the fragrant and the palatable has no correlated resthetic emotion like that which accompanies looking at the beautiful or listening to music. But we doubt the accuracy of this hard-and-fast statement, and are inclined to think that the difference is in degree, not in kind. One of the difficulties is in trying to discriminate between the immediate effect of certain fragrances and that of the pleasant associations which they arouse. And again, while we agree, of course, with Professor Stout that "smells are not adapted to ideal revival in serial succession as sounds and sights are," and therefore do not figure in those trains of ideas which bulk so largely in our mental life, it is not true to our personal experience to say that man has no ol factory memory. Civilization has staked so much on eye and ear, that man's sense of smell seems to be on the down grade. But one hopes that this is still rather individual than racial, that is, rather modificational than variational, and that the growing love for gardens, for instance, may do something to counteract the exhaustion of the sense by tobacco and petrol. One of the hints that we get from Nature is that a fundamental secret of progressive evolution lies in a broadening and deepening appropriation of the complex system 
which has been wrought out through the ages around the organism, and admitting a small minority of stink-horns, hounds' tongues, and corn-spurreys, we would hold firm by our appreciation of that generously widespread frankincense and myrrh which make part of the charm of the summer days. 


\section{XIV. \\ COUNTRY SOUNDS}

AN'S resting instinct is not strongly devel11 oped, and even those who are not tethered to toil are apt to go on working far too long. The stimulus of psychological motives is often strong enough to make us disregard biological warnings, and there are familiar devices, such as a pipe, by which fatigue signals can be muffled. But one of the well-known symptoms of approaching the danger-zone of fatigue is a hyper-sensitiveness to sounds, especially noises, to which unfagged brains with plenty of energy to spare are quite indifferent. Cases have been recorded of the jaded hearing the ringing of the door-bell in a house many yards off, and when ordinary urban sounds begin to be an unusual source of irritation it is a hint to those who can that they should seek the country. For it is beyond doubt that part of a country holiday is in the rest to the ears. The great hush that wraps the hills is more refreshing than sleep.

They say that the noisiest thing in the world is a sun-spot, a roaring whirlpool of gases in the sun's atmosphere sometimes thousands of miles in diameter: but of the whirlpool which Huxley 
discerned in every organism we usually hear no sound. Matter and energy are continually passing in and passing out-a turmoil of molecules, yet all to us seems quietness! There are combustions and explosions, solutions and hydrations, reductions and fermentations; the living body, Sir Michael Foster used to say, is " a vortex of chemical and molecular change"; and yet our ears hear nothing of the bustle. In all these growing creatures round about us in the woods and meadows there is in every dividing cell an extraordinary manœuvering and meticulous splitting of muclear rods, yet all is quieter than a dumb-show. Walt Whitman has spoken, we think, of the bustle of growing wheat, but the striking feature about vital processes is their silence. How quietly are the houses broken down and built up again in the streets of the living body; how silently, like ghosts, do the molecules of these colloid crowds rush past one another! Lucky, indeed, this is for us; in the midst of the crowded life of the country we enjoy quietness, and one panting locomotive in the distance makes more to-do than all the millions of animals and plants, except in the season of the singing of birds (some golfers complain of the larks on the links putting them off their game), and on such unusual, rather artificial, occasions as the separation of the lambs from their mothers. Then the whole night is full of clamor.

In temperate countries, where violent changes are rare, most of the sounds of the inorganic world 
are subdued. There is, indeed, the roll of the thunder, the battery of the angry sea, the howling of the storm, the ominous crash of avalanche and landslip, the roar and cannonading of the forest fire, the groaning and travailing of the earthquake, and the booming of the cataract, but all these are more or less unusual. What we are more accustomed to, what we have come to love, are gentler, subtler sounds with some music in them ${ }^{2}$ - the sob of the sea, the sough of the wind in the wood, the song of the purling brook, the crickle-crackle of the brittle, withered grass and shriveling herbage, the sigh with which the parched ground receives the heavy rain, and the little sound that the breeze evokes when it rings the sun-dried bluebells by the wayside, or makes the aspen leaves quiver, or sets the heather tinkling, or gives a whisper of gossip to the bulrushes beside the lake.

It always seems worthy of remembrance that for many millions of years inorganic sounds were the only sounds upon the earth, for it was not until living creatures had been cradled and fostered for many æons that they found voice. Insects were the first to break the silence, and, as is well known, their sound-production is almost wholly instrumental. Buzzing or humming is mainly due to rapid vibrations of the wings, which often strike the air more than a hundred times in a second, but there is sometimes a special quivering instrument near the

1 This article was published before Sir Francis Darwin's book entitled Rural Sounds (I9I7). 
base of the wing. Chirping or trilling is due to some sort of "stridulating" organ, one hard part being scraped against another, as the bow on the fiddleit may be leg against wing, or limb against body. A true voice, due to the vibration of vocal cords as the air from the windpipe passes over them, began in the amphibians, but did not come to its own till birds and mammals appeared on the scene.

As the inorganic sounds of Temperate zones are, on the whole, less violent than those of the Tropics, so is it also with the sounds made by our animals. They may be included in the reproach implied in Heine's definition of silence as the conversation of an Englishman. How little we have that can be compared with the serenading of the tree-frogs, the orchestra of grasshoppers and Cicadas, the chatter of parrots and monkeys in warmer countries! Except during the time of bird-courtship our country is certainly very quiet. We visited the other day an apiary with about a hundred hives; the air was thick with bees, and their coming and going along the broad glass-covered tunnel of an observation hive was like the Strand at a crowded hour. There were hundreds of thousands of bees, and though the hum was stronger than we ever heard before, even in an avenue of lime-trees in flower, it merely filled the air with a pleasant, tremulous bourdon of sound.

We went in the August gloaming to a beautiful lake hidden in a forest of Scots pine and spruce. As far as one could see there were only two birds 
visible, a pair of dabchicks, diving every minute or two, and uttering now and then the gentlest possible whit-whit which one would not have heard if the hush had not been almost inviolate. Now and again a silvery trout leaped high, suggesting Excalibur; but that was all-till suddenly a ring-dove gave voice, with its deep, rich coo-roo, wonderfully soothing and tender. (One must not allow agricultural interests to obtrude on such occasions.) Not far off, some one, we know not why, had set fire to a giant ant-hill, which was flaming on the top and glowing deep red in its recesses. But from the conflagration, with its tens of thousands of victims, and from the mêlée hurrying from the burning city there came no sound at all. It is not so much that the country is sparsely peopled with animals-a fallacious impression due to the "cryptozoic" habits of the great majority-it is simply that relatively few animals act rapidly on matter, for that is the cause of sounds like the woodpecker's hammering, or the snipe's drumming; and that most of our animals have soft voices, or have not very much to say.

Just as people vary considerably in acuteness of vision, so some hear many sounds which escape others. Thus a keen-eared correspondent tells me that he hears the stroke of a bat's wing and the closing of its jaws on an insect, the munching of a caterpillar, and the rustle of an earthworm.

In midsummer in the North of Scotland there is hardly any darkness at all-one can sometimes see 
to read at midnight, and there are not more than two hours when the larks at least are not singing. The days are now shortening quickly and the silent hours must be longer, yet in the very dead of night we hear the dwellers in darkness on the hunt. There is the hedgehog; for instance, which calls incisively in the stillness with a peculiar voice between grunt and squeal. Even in Aberdeenshire the whir of the nightjar is sometimes heard and the loud clap of its wings together, as it hawks for nocturnal insects, or the vibrating "churr" of the male seated lengthwise on a branch. The shriek of the barnowl and the tu-whit, tu-who of the tawny owl are familiar night sounds, and some people can hear the voice of bats. Soon after cock-crow one is wakened by the rather startling, raucous bark of certain black-headed gulls who come to see whether there are any fragments left where the hens are fed, and they are soon followed by the more cheerful jackdaws. Then, on the adjacent moor, the cock grouse welcomes the sun; swifts then begin their chase-they will be soon leaving us-and their half-triumphant, half-delirious cry, in bad weather and in good; is the last thing we hear at night.

Particular places have their characteristic sounds, which we listen for expectantly. The moorland would be incomplete without the melancholy cry of the curlew, with a melodious ripple at the nestingtime; in the bed of the stream we wait for the oyster-catcher's alarm-whistle keep-keep; by the estuary we enjoy the redshank's warning call with a 
pleasant trill in it, which the male raises to a higher power in spring; among the furze-bushes beside the dry wall the stonechats seem to "chap" the stones together; the peewits cry plaintively from the farmer's fields; as we take a short cut across the heathery " preserve," grouse after grouse proclaims our trespass with a ridiculously silly cachinnation kok-kok-kok; but best of all we like "the moan of doves from immemorial elms."

It is only in manuals of psychology that we get pure sensations and pigeon-holed perceptions, for around all the country-sounds that have become dear to us there have gathered memories, associations, ideas, and we hear with more than the hearing of the ear. There are wonderful "wireless" messages which the imagination can catch. As we walk at nightfall across the common, noiselessly we think, a dog barks just once or twice from a cottage door half a mile away, and then, before the utter quietness is resumed, we hear the children turn in bed, the click-clack of their mother's knitting-needles, the rustle of the newspaper which the shepherd is reading by the fireside; and we see back into prehistoric times when man, whose life depended on recognizing and interpreting sounds, began to evolve the first cousin of a wolf into the trusty guardian of his herds and hearth. So is it with the other familiar country sounds; we hear not them alone, but what they are symbols and sympathetic echoes of; for man is ever reading himself into the so-called outer world. It is his particular magic to hear in the lark's 
miracle of song the music of Shelley and the wisdom of Meredith, to infer the cherubim from the chaffinch, and to find in the "lily-muffled hum of a summer-bee, some coupling with the spinning stars." 


\section{XV}

\section{THE FALL OF THE YEAR}

THE fine days of autumn are rich in quiet delight. They salve our minds through our senses, and we feel the healing power of Nature. The suggestion of frost in the air gives a spice to exercise and braces the body. From the fallen leaves and rustling brittle herbage there rises a pleasant smell, sometimes antiseptic, sometimes like that of ripe apples. Every day the woods have a deeper flush as the leaves slowly wither, and we saw a wild cherry tree on the edge of the hill which burst into flame when the sunlight struck its red leaves-a "burning bush," and no mistake. The children are gathering "brambles," their brightlycolored scarfs and jackets, their red cheeks, their stained lips in pleasant tone with the ripe and ripening berries and with the withering leaves as resplendent as those of the vine. Some bigger boys and girls who had been working all Saturday in the potato field were set free at five o'clock, and it was a pleasant sight when they came bounding over the fence into the road with an alacrity to which the prospect of supper doubtless prompted.

Compared with spring and early summer, autumn is, of course, a very quiet time in the country; 
for most of the singing birds have gone, and the instrumental music of crickets, grasshoppers, and similar phonating insects has stopped for the season. Just as we were thinking of this, however, we heard curlews calling to one another encouragingly as they flew from the moorland towards their winter quarters by the seashore. There are also rooks and gulls, larks and robins, and a few other birds to be heard. Large numbers of lapwings have been very busy lately hunting small deer in the bare fields, and some are speaking in a subdued way to one another as they unite into bands to migrate from Aberdeenshire to Irelandone of their favorite autumnal journeys. At the same time it must be admitted that autumn is not very vocal, and we have to put the gain in color against the loss in sound. The rather overwhelming greenness of the vegetative period has been replaced by a great variety of hue, as when white light is split up by a prism, and though the splendor of individual flowers has passed, there are big splashes of color that offer compensation.

So much for sensory delight, but there is also a wealth of scientific interest. The great wave of life gathers strength in spring, rises to its full height in summer, sinks to rest in winter; the breaking time is autumn, and no season is richer in problems. We stoop and look along the links towards the sinking sun, and we see the quivering of myriads of fallen gossamer threads which earlier in the day served multitudes of small spiders as silken para- 
chutes. From a crowded area the little spinners were borne in passive migration on the wings of the wind, and the tangle of gossamer on the grass tells of the accomplished journeys. In the forenoon the threads glisten with dew or thawed hoar-frost, making one of the finest sights in the world"every thread of cobweb dew-bediamonded," as R. L. Stevenson put it-and all the finer in our eyes because we know that the gossamer strewn in disarray spells a victory of life over matter. Showers of gossamer are not by any means restricted to autumn, but they are in many localities very characteristic of that season, and we may link them in thought to the more active migrations of birds-migrations which have taken from us all our summer visitors and are bringing us a small contingent of winter visitors, such as fieldfares and redwings, snow buntings and great northern divers. There are also incoming flocks of various sorts (gold-crests and hoodie-crows make a good contrast) which take Great Britain en route as they wend their way from Scandinavia to the genial South.

Another very characteristic sight in autumn is the rush of the salmon up the rapids and over the falls on their way to the spawning-grounds where the females deposit their eggs in the gravel-usually in November and December in Scotland. Their nutritive period in the sea has given them great stores of energy for their fasting but reproductive period in the rivers; they are influenced, no doubt, 
by the temperature and oxygenation of the water and so on; they are impelled by an internal spura seasonal change of constitution; but in thinking over this return to their natal waters, or to waters similar in character, we probably go far wrong in the direction of false simplicity if we do not recognize in the salmon struggling against the stream a bent bow that is more than material. We mean that in its way the salmon is a personality-a piscine personality if you will-with a life not only of contracting and relaxing, digestion and combustion, and so on, but a life of feeling and willing besides, the two making one. And just as the salmon illustrates an intensely active genetic impulse, the expression of physiological and psychical enregistrations both racial and personal, so in these windborne clouds of winged fruits and parachuted seeds we see on a very different level and with little hint of "the bent bow" the same fascinating problem of adaptations which secure the continuance of the race from generation to generation.

The familiar withering and fall of the leaves can never fail to excite the interest of those who keep alive the curious spirit. What busy synthetic laboratories they have been all the summer through, what abundance of complex carbon compounds have they manufactured! and now the laboratory furnishings are worn out and the leaves must die. But there is high art in their dying; for there is a migration of almost all that is valuable from leaf to stem, so that little more than waste is left to fall; 
there is the fine surgery which cuts the link between dying and living and at the same time bandages the wound (recalling quaintly enough the throwingoff of a leg in crab and lobster); and there is the "beauty for ashes" due to the breaking up of the chlorophyll and the formation of special decomposition pigments like anthocyan. And, looking ahead, we see the earthworms dragging the fallen leaves into their burrows, and thereby making vegetable mold in which they sometimes, all unconsciously, plant the seeds of future trees. We wonder whether there is in animate Nature any more beautiful sequence of adaptive events.

The wasps' nest, a model of "efficiency" in the summer-time, is falling into ruins; all the tenants have gone, and intruders are pillaging the edifice. The ranks of the workers were thinned weeks ago by bad weather and cold; the parent queen died of exhaustion; the surviving workers ate up the remaining grubs and died also; the drones likewise disappeared, so now the sole survivors of the colony are the young queens, who, after mating, sought out secluded corners where they have fallen into their "winter sleep." For humble-bees the story is in a general way the same; only the young queens are left, hidden in their winter quarters. Contrast this, however, with hive-bees under man's ægis. The elaboration of the storing instincts, the greater division of labor and solidarity, and the more permanent "hive" have made it possible for the 


\section{6}

\section{SECRETS OF ANIMAL LIFE}

community to evade the terrific autumnal elimination seen in ordinary wasps and humble-bees. The activities in the hive sink to a minimum, it is true, but the point is that the community lasts, and in a favorable year should not, after yielding much honey to their owner, require any winter feeding from him if he is not too greedy in what he exacts. But every one knows that there is autumnal tragedy in the beehive too, for some time after the queen has been fertilized the workers unite to destroy the now useless drones, either murdering them directly or driving them forth to perish.

Deeper than the particular problems of the natural history of autumn is the general biological problem of what it all means, and the answer is that the seasons are externally instituted periodicities to which organisms have had to adapt themselves. But it is not merely that living creatures have become in a self-preservative way fitted to cope with or circumvent the difficulties of the seasons; they have also evolved subtle tactics which have made use of the difficulties as opportunities for advance. Just as the alternation of hard work and quiet rest, physiologically natural in higher animals, fits in well with the alternation of day and night, so rhythms of longer period fit in well with the periodicities of the seasons. It cannot be said that the alternation of work and rest, including, for instance, the "loading" and "unloading" of internal glands, is the direct and necessary result of the alternation of 
day and night, for some creatures, such as hive-bees, work all night as well as all day; and similarly it cannot be said that the periodicities of the seasons are the direct causes, say, of the winter blanching of the mountain hare and the ptarmigan, or of the hibernation of hedgehog and bat, or of the migration of most North Temperate birds. All that we can say is that external periodicities and internal rhythms have interacted for ages so that an adaptive adjustment has been arrived at.

What do we see, then, in the tactics of autumn? In the first place, there is a great variety of arrangements for the continuance of the race even when the individual lives come to an end. This is illustrated by the autumn fruits and by the prodigal seed-scattering, by the salmon rowing hard against the stream, by the queen wasps and queen humblebees seeking out winter quarters, by the honey-bees snuggling together in the hive. In the second place, there is a sacrifice of parts which saves the whole, as when the leaves fall from the trees which they have enriched, or when the hive-bees massacre the drones, or when there is terribly drastic reduction of numbers among wasps and humble-bees. In the third place, there is preparation for hard times to come, as is illustrated in the automatic vegetative storing of starch and the other reserve products by plants, in the instinctive storing of honey by hivebees and of grain by ants, and in the half-instinctive and half-intelligent storing of nuts by squirrels and of earthworms by moles. There is the making or 
collecting of blankets against the winter's cold, as is illustrated by the non-conducting scales around the buds, by the sleeping-sacks which caterpillars fashion before sinking into their chrysalid lethargy, by the soft quilts gathered into their winter restingplaces by dormice and other true hibernators. The blanching of mountain hare and ptarmigan is also a protective preparation. In the fourth place, there is what one may dare to call the circumvention of difficulties. The clearest illustration is in the migration of the majority of North Temperate birds to comfortable winter quarters in the South. They evade impending disasters so triumphantly that they know no winter in their year. Or, again, in true hibernation of hedgehog and bat, dormouse and marmot, there is a relapse from the normal "warm-bloodedness," a seasonal sinking back toward an ancestral "cold-bloodedness," which leaves the creature less open to the assaults of the winter; able, indeed, to defy them, especially within a secluded, confined, and of ten well-blanketed sleeping chamber. Even in the lethargy of tortoise and frog, snail and chrysalid, which must not be mixed up with true hibernation (confined to a few mammals), there is the same general idea of relapse into a condition of "lying low" physiologically, which renders the creature much less open to attack. The fire of life, well banked up, almost smothered in its own ashes, burns very low through the night of winter, and "keeps in." No doubt the fall of the year means retrenchment and sacrifice, retreat and 


\section{THE FALL OF THE YEAR}

sifting; but those who study the biology of autumn attentively will recognize much more-a multitude of adaptations, automatic, instinctive, and intelligent, which secure continuance, persistence, victory. 


\section{XVI}

\section{THE SURVIVAL OF THE OTTER}

$7 \mathrm{HE}$ otter is so shy a creature that few British naturalists have had more than tantalizing glimpses of its everyday (or rather, everynight) life, wherewith to supplement what they know of the animal in zoological gardens, and what they have gathered from a study of its structure-the finely-molded skull, for instance. This gap in our knowledge was filled a few years ago by Mr. J. C. Tregarthen's Life Story of the Otter. ${ }^{1}$ The author's observational patience and sympathy, shown also in his biographies of fox and hare, have enabled him to disclose the vie intime of an animal which is, to say the least, very unapproachable. We hope that our appreciation, at once of the beast and the book, will serve to introduce Mr. Tregarthen's delightful studies in Natural History to some who have not had the pleasure of knowing them. The question with which we are especially concerned is how the otter manages to hold its own in Britain, where so many of its Order, such as badger and wild cat, polecat and marten, have become very few and far between. It is not enough to refer to the otter's cerebral endowments, its keen senses of

${ }^{1}$ Murray, London, I9I5. 
sight, hearing, touch, and smell, its muscular equipment, so marked in the grip of its jaw, the backstroke of the hind-legs, and the sweep of the steering tail, for the mammals we mentioned above are not deficient in these qualities, and yet they have nowadays a tenure of life much less secure than the otter's.

What particular virtues has the otter that enable it to keep its foothold in spite of man's persecution and the reduction of natural preserves? The general answer is probably that the otter has relatively few wild enemies, and that it is one of the most elusive of beasts, in great part nocturnal in its activities, shy of repeating itself, shifty in its hunting, and very thoroughly amphibious. Mr. Tregarthen calls attention also to the faintness of the otter's scent, " noticed by few dogs save hounds that have been trained to own it," and to its resourcefulness and endurance when hunted. Part of the secret of survival must also lie in the catholicity of appetite, for while the otter depends in the main on eels, trout, salmon, pike, flatfish, and the like, it condescends to the mussels on the seashore (biting through their shells), the limpets on the rocks, and the frogs on the marsh, and rises to wild-duck and rabbit. It must also be remembered, as in regard to fox-hunting, that.whatever be our humanitarian or artistic views in regard to the otter-hunt, the probability is that sportsmen, who leave the cubs unmolested, make for the otter's survival rather than for its disappearance. The zegis of sport 
has saved the creature from being exterminated for the sake of its fur. ${ }^{1}$

One of the admirable qualities of the otter is the intensity of the parental, especially the maternal, care. The young ones-blind and downy-are born in a soft-lined nest under the shelter of an inaccessible bank; the mother will at first hardly leave them save on feverish rushes after the food necessary to keep up the supply of milk. To guard them she sleeps, like many a human mother, with at least one ear awake. When they open their eyes she cautiously carries them to bask for a while in the winter sunshine, for their birthdays are often in January. When they can clamber she teaches them the woodcraft of the immediate vicinity of the "hover" and the complete alphabet of the sounds that mean danger. With her teeth she punishes disobedient foolhardiness-especially on the part of the male cubs-yet she shares in their frolics when all sensible danger is distânt. When they are a little over eight weeks old and able to follow her afield, she takes them to a quiet pool and teaches them to swim, supplying by a gradual widening of experience the liberating stimuli that are needed to arouse their instinctive endowments. In about a week they can swim with the fishes-a week which seems more like play than school, for the otter is one of the animals in which there is pro-

1 For the other side of the picture-a sorry one-see Joseph Collinson's. Hunted Otter. Animals' Friend Society, London, Igrr. 
longed playfulness in youth-a period of irresponsible and apparently joyous apprenticeship to the future business of life. Who shall say that the mother does not in some measure renew her youth as she shares in the "hide-and-seek" and gambols of her cubs? It is indeed a remarkable fact in regard to this fascinating animal that playfulness never quite leaves it; that even the fathers and mothers of families cannot resist the appeal of situations that suggest a frolic, and that they will play up to the very gates of death- "most playsomest critturs on God's earth," said one of Mr. Tregarthen's Cornish friends.

To return to education, the young cubs have also to learn to like the taste of fish, to catch them without fuss, and to eat them in the proper waythe eel from the tail and the trout from the head. They have to learn how to catch frogs and how to skin them, for the outside is unpalatable; how to guddle for trout and eels; how to detect the plaice in the shallow waters of the bay, hidden in or against the sand, with only their eyes showing. They have to learn how to deal with rabbit and moorhen, and, through it all, they have to keep working away at the long alphabet of dangersounds-especially those proceeding from man and dog. They have to learn all the diverse ways of lying perdu in and out of the water. There can be no doubt that the prolonged youth and the elaborate parental instruction count for much in the persistent survival of the otter-a kind of fact still 
inadequately appreciated by those who hold to a conception of the struggle for existence which is too literal and wooden to be accurate.

Another attractive feature about the otter is its nomadism; it has the roving spirit. "The homeless hunter," Mr. Tregarthen calls it, "the Bedouin of the wild," "It has been known to travel fifteen miles in a night, and not infrequently the holts where it lies up during the day are ten or twelve miles apart." It passes from tarn to stream, from river to shore; it swims far out to sea and reaches isolated rocks; it wanders along the cliffs and explores the caves; it crosses the heather-covered hills, and even the mountain passes, sheltering among the bracken or in the heart of a cairn; it neither stores nor hibernates, but is always on the move-a gipsy among carnivores.

Resourceful is the appropriate word for an otter. For it is equally at home on land and in water, by night and by day, in a dry burrow or on a shelf under a waterfall; it can enter the water without a splash, swim near the surface with scarce a ripple; it can dive in a spiral full fathoms five, and lie under the bank on a stream for hours with its nostril in a space between water and earth. It knows its own footsteps in the thicket and will not retrace them; it never goes back to a kill, for that way danger lies; it will carry a water-trap on its shoulders and wrench it off on the alder-roots; it will dive at the flash of the gun and elude the bullet; it is an outlaw of unsurpassed alertness and resource. 
There are savage fights between two dog-otters who desire the same mate, and the strength of the parents is often severely taxed in providing for the young; but the main struggle for existence among these sharp-toothed, strong-jawed beasts of prey is not in any intra-specific competition, but in circumventing difficulties and in securing food.

The severest of tests is a hard and prolonged frost. At first it gives an added spice to life, for strings of wild-fowl arrive and the ice on the mere is a rare playground. It is possible for the otter to hunt for pike beneath the ice, for eels and tench buried deep in the mud. But there is circumstantial evidence of terrible experiences when the breathing holes in the ice freeze quickly and the otter is apt to be imprisoned below, when the parents are tied down by cubs too heavy to carry and not strong enough to travel, when the wild-fowl leave the sealed waters for the shore, when the snow threatens to smother the family. It is only in such straits that the otter, in desperation, begins to experiment by nights with the farmer's ducks. This last resource is very restricted, however, and the conditions may prove too severe, the mother at last succumbing to her efforts to get food for herself and her offspring. "At Mullion, in Mount's Bay, one bitterly cold December, when the Poldhu stream was frozen and the sea too rough and discolored for the otter to fish, the poor creature in her extremity crept into a bungalow in the course of erection, and was there found curled up 
dead." We are indebted to Mr. Tregarthen for enabling us to combine in a living whole sundry personal glimpses we have had of this attractive but inscrutable creature's life, and for giving us in answer to our question regarding its survival these hints, that in addition to great natural gifts the otter has the advantage of a most solicitous mothering, of a careful education resulting in a resourcefulness that can hardly be baffled, and of a roving spirit which becomes expressed in an unrivaled elusiveness. Britain will indeed be the poorer if man's ruthlessness prove eventually too much for a fascinating creature whose grip has held for so long. 


\section{XVII}

\section{MIDWINTER}

$7 \mathrm{HE}$ biological signficance of a season is clearest in extreme cases, and there is no obscurity about the meaning of winter on the slopes of the Cairngorms. The keen edge of what would have been but a breeze on a summer day suggests the reaping-hook of elimination-both discriminate and indiscriminate-which every winter implies. The blankets of snow make us think of sleep and rest, and so does the silence. One remembers how many months Nansen spent in the Far North without hearing the voice of a single bird. Even the curlews have long since left the moorland for the shore, there are almost no footprints on the snow, and we have the feeling of being intruders into an azoic domain. Of course it is not so bad as it looks, for now and then we literally catch the eye of a ptarmigan in winter dress, so subtly camouflaged among the snow, and that movement of a something with a cloak of invisibility was the rush of a startled white hare. No doubt there is considerable cryptozoic life about the roots of the heather and so forth; in Canada the ruffled grouse dives into the soft snow-drifts and makes a short tunnel; but the general fact is that most of the living creatures 
which were here a few months ago are asleep, or have gone on a journey, or have, as individuals, ceased to be.

The wintry aspect of the realm of organisms must be considered from within and from without, for life is rhythmic and is punctuated by the seasons. On the one hand, there is a deep reason why highlevel activity cannot be for long continuous, why it must be interrupted by periods of rest. It is not merely. that the living engine has to be stoked; it is that the framework requires opportunity to keep passably young. It is continuity that kills. For many creatures winter is the time when processes of rejuvenescence get a chance to counteract the encroachments of senescence. How useful, often, for the overworked brain is it to sleep the round of the clock. The hibernal slumbers of hedgehog and dormouse, of marmot and bat, the winter coma of tortoise and slow-worm, the lethargic condition of frogs and snails, are no doubt adaptive reactions to severe external conditions, subtle organic illustrations of Brer Rabbit's policy of "lying low and saying nuffin"; but our point is that the quiescence of winter has in some cases a more internal aspect, it is the inevitable pause in a strenuous life. Quite extraordinary in some humble, but intensely active, animals (Bryozoa, for instance) is the way in which the framework can be periodically taken to pieces and built up again. One suspects that organic immortality is commoner than is usually supposed. And the recuperation has obviously a prospective 
as well as retrospective reference; it is the crouch before the leap. Many an organism has learned the lesson, se reculer pour mieux sauter. The repose of winter gives us the rebound of spring.

On the moor a few hundred feet lower down there are scattered birch trees with bare limp branches on the pendulous tips of which the sun has hung diamonds; what a story they have to tell us of the precarious tenure of peripheral organs (as the birch leaves fell the grouse molted its claws!); of the usefulness of surrendering vulnerable organs; of the economy of the organism, for the leaves in their withering gave back to the tree all that they had that was worth keeping; and of the preparations made many months ago within the wellprotected buds for the foliage and flowers of the distant spring.

From the external aspect the big fact is that the rate of chemical reactions is increased by rise of temperature, since that means increase in the rate of molecular movements. It is true that what is called van Hoff's Law of the effect of temperature on chemical reactions does not seem to fit very well for the changes that go on in living creatures, probably because these are such heterogeneous systems, in which physical and chemical processes become intricately mixed up; but the broad fact is that the effect of warmth is to increase, and the effect of cold to decrease, the rate of vital activity or metabolism. Moreover, in spite of glacier-fleas and small creatures from hot springs, the great 
majority of active animals are going concerns between very narrow limits of temperature. A little too hot, or a little too cold, and the wheels won't go round any more. We need not go into the question of the effect of cold on the synthesis of proteins, on which the continuance of vigorous life depends; and we confess our inability to explain the metabolism of deep-sea fishes, for instance, which live and thrive-at what pace we do not know-in the eternal winter of the great abysses where the temperature remains, year in year out, about the freezing-point of fresh water; but the average statement is safe that winter puts a brake on vital activity. Should the brake be put on too suddenly or too forcibly, the equipage of life may be capsized and broken, and all the king's horses and all the king's men will not be able to put it to rights. As many as two hundred dead birds have been gathered in one stackyard after a night of severe frost. The thermometer fell just a little bit too far-beyond the limit of a bird's viability.

So it is no small part of the biology of winter to inquire into the diverse ways in which living creatures have learned to meet, or are learning to meet, the time of cold and scarcity. The finest solution of all is that of the migratory birds, "intelligent of the seasons," as Milton put it, who circumvent the winter by seeking lands that keep the sun. Very effective is that long result of time called warm-bloodedness, whereby birds and mammals are able, up to a certain limit, and in varied 
degrees of perfection, to adjust the internal production of heat to the external loss of it, and thus keep an approximately constant body-temperature all the year round. In some mammals in which this "thermotaxis" arrangement is less perfect than usual, there is a breakdown when the cold comes on. The creature gives up the contest and sinks into deep slumber in some confined space, to the temperature of which that of the sleeper approximates. If the external temperature does not fall too far, this hibernation may be life-saving. Similar, but less effective, is the lethargy of cold-blooded animals like tortoises and frogs, the vital collapse of snails and chrysalids, and the inactivity of many humble creatures in sheltered nooks and crannies. They evade the winter by their extreme passivity; they cannot carry on, but they do not die.

We are led to think of stores, whether inside the body in the form of fat which may be slowly burnt away in winter months, or outside the body in the form of nut-pits, seed-granaries, meat-larders, and what not. The climax on the instinctive tack of evolution is to be found in the societary stores made by ants and bees. Of another solution we are reminded by the ptarmigan and the hare that we startled, good examples of creatures that turn pale under the spell of winter till they are white as the snow itself. The white cloak may help in concealment and in the chase; it also furnishes the physiologically most comfortable dress for a warmblooded animal in very cold surroundings. We 
must not go farther; our point is merely to suggest an interesting inquiry into the great variety of ways in which different animals solve the same problem of surviving the winter. For those that have no solution to offer, and for those that fumble with their solution, winter spells sooner or later elimination.

As we come home we pass a little tarn, which was such a merry, busy place at midsummer, but is now half-frozen, and looks as lifeless as the moor. The water round the edges is clear and clean, but peering down we cannot see the slightest stir of life. Now the biochemists of the ponds have told us a very interesting thing: that the dying away in autumn and winter produces substances ("auxetics") which later on promote the multiplication of cells and towards spring an increasing quantity of certain other substances ("augmentors") which give more power to the elbow of the first. And so out of death come the stimulants of the wonderful awakening of pond-life in spring. There is, no doubt, in that tarn an abundance of life even now, but it is in hiding, it is in winter-retreat, it is waiting. And as we look at the partial covering of ice another thought rises in our mind which lasts us all the way home: the thought that this world, in spite of all Man's cataclysms, is singularly well adapted for going on. For there is surely food for reflection in the fact that fresh water is anomalous in expanding, not contracting, when it is near its freezing-point. This brings the coldest water to the top, thus tending to 
lessen the loss of heat from the warmer water below. The coat of ice, once formed, remains on the surface by its buoyancy, the warmer water below is kept fluid, and the life of plants and animals is able to continue. That floating sheet of ice is a diagram of the moving equilibrium of the world. 


\section{XVIII}

\section{THE MICROCOSM OF THE EGG}

ARWIN called the brain of the ant the most marvelous speck of matter in the universe. It is so intricate for its size-less than that of a pin's-head; it is the repository of so many ready-made tricks. But even more marvelous than the ant's brain is the much minuter ant's eggcell (what we buy as "ants' eggs" are pupæ undergoing metamorphosis), which, in a manner that we cannot begin to imagine, contains the potentiality of the whole insect and of all its instincts as well. The more we know about the ovum, the more the wonder grows. It may be of interest, then, to look for a little into the pit whence we were digged, and upon the rock whence we were hewn. For, like most other living creatures, we all begin as fertilized egg-cells. A convenient up-to-date account of the whole matter will be found in Professor Brachet's L'Euf ( I917), a brilliant course of lectures which this embryologist of Brussels has recently delivered at the College de France.

The egg-cell, or ovum, is typically a very minute living unit. The dark-colored ovum of the frog is about one-tenth of an inch in diameter, but this is gigantic rompared with the ovum of most 
mammals, where a common size is one-tenth of a millimeter, say a tenth of the diameter of an average pin's-head. In the large eggs of birds, reptiles, sharks, and the like, the bigness is due to the accumulation of a huge capital of yolk. On the top of this there lies a drop of formative living matter, like a miniature watch-glass turned upside down. The egg-cell of a whale, containing the potentiality of the colossal creature, is no larger than fern seed; and it is worth noticing that the male-cell or sperm-cell is, according to the kind of animal, several thousand times smaller than the egg-cell, and thousands of sperms may rush around in a drop suspended from the head of a pin.

In spite of its minuteness, the egg-cell contains many different kinds of components, which are often, if not always, disposed in zones or after some specific pattern. According to one school, the regions of the egg differ qualitatively, some having particular "organ-forming substances" which others have not; according to another school, the regions differ quantitatively in the degree of concentration and in the rate of reaction of the constituent formative materials. Probably the truth is with both schools. Delicate experiment has made it certain that in some egg-cells, e.g. those of sea-squirts (Tunicates) and sea-gooseberries '(Ctenophores), particular areas of the egg, sometimes distinguishable by their color, will normally develop into particular organs of the animal. On the other hand, the pattern of most egg-cells is not 
to be compared, as Professor Brachet says, to a harlequin's coat, composed of non-interchangeable pieces. For a part of an egg is often as good as the whole, in the early stages of development at least; and a relatively large piece of the ovum may often be cut off without doing the future embryo any harm. Besides the nutritive yolk, which the egg usually builds up from materials furnished by the parent, it elaborates, as M Fauré Fremiet has shown in a unique research, a variety of other chemical substances which are among the buildingstones of future structures. And besides these bodies which the egg-cell makes for itself, there are often $a b$ initio others, with weird names, such as mitochondria, which are regarded by many as definite inheritance-vehicles.

Lying in the midst of the complex cell-substance, which often shows an intricate microscopic structure (reticular or otherwise), there is a nucleus-a microcosm within a microcosm. For inside this nucleus there are all sorts of things, notably a definite number of readily stainable bodies or chromosomes, which again may be resolved into beads of chromatin embedded on pieces of a transparent (linin) ribbon. The number of these chromosomes is definite, e.g. 24 for mouse and lily, and each cell throughout the whole body usually adheres to the, characteristic number. So each species, like the Beast, has its number. Some say that a white man has 47 and a white woman 48 , and a negro only 22 ; but in case any political advantage be taken of this 


\section{THE MICROCOSM OF THE EGG 137}

statement, we hasten to add that 48 is also the number of the snail and of one of the varieties of banana. In truth, the important fact is not the number itself, but its persistence; and that is only an instance of the doggedness of specificity.

One of the outstanding results of the intricate process of ripening or maturation in the history of the germ-cells is that the number of chromosomes is reduced to one-half. When the sperm-cell and the egg-cell unite in fertilization the normal number is restored. In the case of the egg-cell the reduction usually takes place in the formation of the first of two polar bodies-minute daughter-cells of the ovum that come to nothing. If the chromosomes of the egg-cell be compared to a pack of cards, half of the pack may be said to be thrown away prior to the beginning of each individual life. If the chromosomes are the bearers of hereditary qualities, the halving of the pack may be one of the opportunities for fresh permutations and combinations, which form the raw material of evolution. The ripe ovum, after a brief attempt to go on actively living, sinks into static equilibrium. It is paralyzed by its own waste-products (auto-intoxication), and becomes relatively impermeable to outside influences.

As every one knows, what normally reawakens a certain proportion of the mature ova from their inertia is fertilization. This implies many distinct occurrences. (I) The sperm-cell enters the egg-cell and there is an intimate and orderly union of the 
chromosomes, which probably bear respectively paternal and maternal hereditary qualities. According to Professor Brachet and some other authorities the sperm-cell is not important in connection with the transmission of specific characters-that is the ovum's rôle, but, in addition to its chief function as "an agent in division," it may be credited with being the vehicle of minor personal features characteristic of the male parent. This view is a blow to proud fathers, but it is probably the exaggeration of an element of truth into a falsity. (2) The fertilization, as we have mentioned, restores the normal quantity of chromatin and the normal number of chromosomes. In some cases, especially among insects, it has been proved that there are two kinds of sperm-cells, one contingent with, and the other contingent without a special sex-chromosome, and that the sex of the offspring hangs on the fertilization. Thus an even number of chromosomes in the fertilized ovum may mean a female offspring, while an odd number may mean a male. In other cases, however, the sex of the offspring is determined by the physiological character of the egg-cell, quite irrespective of fertilization. Thus Professor Oscar Riddle has shown in pigeons that the eggs with less intense metabolism and greater storage capacity develop into females. (3) The entrance of the sperm-cell implies the advent of a minute body called the centrosome, a mountain-moving mouse, which divides into two, and plays an important part in the subsequent division, acting, as it has been 
said, as the weaver at the loom, the paternal and maternal contributions being the warp and woof of the future web. (4) When the sperm-cell enters, a wave of contraction, starting from the upper pole, passes through the ovum, and a small quantitiy of fluid is expelled which insinuates itself between the surface of the egg and the innermost layer of the egg-membranes. (5) Finally, the sperm-cell sets up awakening changes in the living substance of the egg, which then passes from static to dynamic equilibrium. The formative materials are redistributed and stabilized in a direction determined by the meridian of the sperm's entrance. This new architecture is respected in the subsequent cleavage of the developing egg. Another effect is that the living substance of the ovum becomes suddenly refractory to the entrance of another sperm-cell, which would be apt to induce monstrosity. This "blocking" of the egg-cell is sometimes accomplished by the contraction, already referred to, which shuts a little gateway (micropyle) present in the egg-envelope of many ova.

One of the most interesting chapters in modern biology concerns artificial parthenogenesis, i.e. experimental ways of launching an unfertilized egg on the voyage of development. Most bee-experts believe that unfertilized eggs laid by the queen develop into drones, who, therefore, have a mother but no father. This is natural parthenogenesis, and there are many other instances. But it is now known that in a variety of cases, from sea-urchin to 
frog, artificial parthenogenesis, followed by normal development, can be induced in egg-cells which invariably require fertilization in the ordinary course of nature. Professor Jacques Loeb's chief method is to subject the ova, say of sea-urchin or starfish, first to the influence of some fatty acid, like butyric, which leads to oxidations in the cortex of the egg, the formation of a membrane of fertilization, and so on. The egg is activated, and if the process continues it ends in disintegration and death. But if at an appropriate time the activated egg is subjected to hypertonic sea-water, this acts as a corrective of the impending dissolution, and brings the egg back to a safe path of normal development. Professor Yves Delage's chief method is to subject the ova of sea-urchin or the like to the combined action of tannin and ammonia, the former tending to coagulate, the latter tending to liquefy, the colloid substances which make up the egg. Most of the ova, when restored to sea-water, develop and form normal larvæ; in two or three cases the adult form has been reached. Bataillon's chief method is to prick frogs' eggs with a very fine stylet of glass or platinum, and then wash them with blood. The first event provokes activation; the second event allows the entrance of an organic center (a blood corpuscle, and not necessarily a frog's!) which initiates a well-balanced ovumsegmentation. Two or three parthenogenetically developed frogs have been reared; they are normal, and of both sexes. 


\section{THE MICROCOSM OF THE EGG 141}

Another kind of experiment shows that a half or less may be as good as a whole. By delicate methods of microscopic vivisection, Professor Delage was able to cut off non-nucleated fragments from a sea-urchin ovum. They accepted fertilization, however, and developed into embryos. In many cases, when a fertilized egg-cell has divided into two cells, these can be shaken apart with the result that each develops into an entire animal. If in the two-cell stage of the developing frog ovum, one cell be punctured with a heated electric needle, the remaining cell will develop into a one-sided hemiembryo or into a half-sized whole embryo, according as the punctured ovum is kept fixed or allowed to move (and readjust itself) in the water. Indeed, if a part of an ovum or of a developing ovum is to serve as the equivalent of a whole, the essential condition seems to be a restoration of the typical topography and a re-establishment of the proportions of materials. If a vessel of sea-water containing developing eggs of the lancelet be shaken at the two-cell stage, the result, according to the amount of shaking, will be a double supply of dwarf embryos, or a set of Siamese twins. Even at the four-cell stage, the shaking will result in numerous dwarf embryos, or in queer Siamese triplets and quadruplets. Perhaps, however, we have said enough to suggest the wonder of the egg-cell, and to make this certainty clear, that no easy-going view of the microcosm is in the direction of the truth. 


\section{XIX}

\section{THE CURVE OF LIFE}

TO Huxley it seemed that one of the most I significant characteristics of living creatures was their "cyclical development." From a microscopic egg-cell an embryo plant develops; the ovule becomes a seed, the seed a seedling; by insensible steps there is formed a large and varied fabric of root and stem, leaves and flowers. But no sooner has the edifice attained completeness than it begins to crumble. The grass withereth and the flower thereof fadeth, and soon there is nothing left but the seeds, which begin the cycle anew. It is, Huxley said, "a Sisyphæan process, in the course of which the living and growing plant passes from the relative simplicity and latent potentiality of the seed to the full epiphany of a highly differentiated type, thence to fall back to simplicity and potentiality again." So is it also among animals. The microscopic egg-cell divides and redivides, and there is built up an embryo. This may develop steadily and directly into the likeness of its kind; or it may give rise to a quite divergent phase-a larva of some sort-such as caterpillar or tadpole, which by and by undergoes metamorphosis and gets shunted on to the direct line of ontogeny. 
Through more or less critical phases of adolescence it becomes adult. It is a not infrequent achievement to lengthen out the period of mature strength, but sooner or later the edifice begins to crumble. This creature's life is counted in days and that other's in months; we reckon ours in years and the Sequoia's in centuries, but there is for most an ascending and descending curve from the vita minima of the egg-cell (which often dies in a few hours if it be not fertilized) to the vita minima of the outworn creature if the conditions of life admit of senescence, which as a matter of fact is in most cases evaded among wild animals. But part of the fascination of the study of life-histories is to be found in a recognition of the fact that they often differ from one another as different forms of a melody do when the "time" of the various parts is altered, and that this variation in rate is often finely adaptive to particular conditions-i.e. is a solution of special problems of life. The morphologists are beginning to discern that one type of skull, or one shape of fish, or one contour of leaf, may be derived from another by supposing a slight deformationlet us say, a tilting - of the whole architecture, and the idea that we wish to illustrate (it is essentially traceable to the fertile brain of Professor Patrick Geddes) is that one creature's life-history often differs from another's in a change of rate or rhythm, in an elongation of one part of the life-curve and a compression of another.

$A^{\prime}$ familiar kind of life-history is that into which 
a prolonged larval period has been interpolated. Out of the egg-shell of a cockroach there comes a miniature of the adult, but out of a butterfly's there emerges a minute caterpillar with very little hint of its parentage. It feeds and grows and molts its husk, and this logical sequence is repeated over and over again. The caterpillar gains strength and stores up nutritive reserves; it undergoes a remarkable metamorphosis, most of the old larval body breaking down and a fresh start in development being made on a new architectural plan. Eventually the winged butterfly emerges, as it were, by a second birth, and enters upon a phase of life which is preoccupied with reproduction and only secondarily (if at all) concerned with nutrition. The relatively long caterpillar period makes the ecstasy of the butterfly possible. A very remarkable achievement has resulted from the lengthening out of the larval phase, and in many life-histories we hear, so to speak, the same tune. The mayflies or Ephemerides are often almost diagrammatic, for many have two or three years of subaquatic larval life and two or three days (or less) of aerial and reproductive activity. In the sea-lamprey we find a somewhat similar punctuation of life-but it is notably improved upon. For after a long larval fluviatile period, sometimes of four years, there is a phase of vigorous adolescence and adult life in the sea. But the curve ends in the same way-an almost vertical drop after reproduction. In the common eel there is a greatly elongated larval 
period, lasting it may be for a couple of years, during which the fish makes its long journey, often of a thousand miles, from the open sea to the rivers and ponds, and there is a long youthful growing period, for several years, when energy is accumulated for the short strictly adult period which involves a return journey to the sea and ends apparently in death as the nemesis of spawning.

Another type of life-history implies a suppression of the larval period and a lengthening out of the embryonic development within the egg-shell or eggenvelope. A good instance is to be found in a class of unfamiliar but widespread primitive animals, known as Onychophora, of which Peripatus is a representative genus. They are interesting synthetic types with certain features of insects and others of segmented worms; they are doubtless survivors from very ancient days, keeping a precarious foothold in many parts of the world in virtue of their shyness and their nocturnal habits. Now all these characteristically cryptozoic creatures are viviparous, and the young they bring forth are from birth miniatures of the adults. Moreover, the period of embryonic development is prolonged, sometimes lasting a year. Contrasting this with the life-history of a higher insect, we see that in the latter embryonic development is shortened to a minimum and the larval phase lengthened out extraordinarily. In birds the time that the parents can afford to spend in brooding is limited by the conditions of food supply, temperature, and the like, 
and in consequence the period of embryonic development has been relatively shortened or condensed. The cock that crows in the morn is, on the whole, except in brain, as complex a creature as the cow that tosses the dog, but the chick breaks its way out of the egg after three weeks of incubation, whereas the calf is carried by the cow for about nine months of antenatal life. In the contrast between the callow nestling type, which corresponds to prolonged infancy, and the precocious chick type, which corresponds to abbreviated infancy, we have another familiar illustration of the elasticity of the curve of life. How striking is the case of the Mound-Builders, where the mother-birds have evaded brooding and where the young, hatched within the heap of fermenting vegetation, are able to fly right away. The great majority of fishes are oviparous, with both embryonic and larval phases in the water. In this there are great risks and the juvenile mortality is enormous. Yet, as there are plenty of fry to spare, most species of modern fishes continue to prosper. But how vivid is the contrast between their life-curve and that of the whale, with a single calf slowly developing within the mother and born into the sea a fully-formed and richly endowed cetacean. Just as there are plants which remain for life like half-opened buds, and others which flower before they leaf, and so forth, so there are animals which have a long youth and others a long maturity, some that are born old and others that die young; some which break down suddenly 
in their prime and others that seem to have no limit (save violent death) to their persistent growth. It is a question of vital punctuation.

Just as there are many novels but only a few plots, so amid an apparent multiplicity of lifehistories we discern but a few main types. The details may seem very different, but they are often interpretable as due to a lengthening out here and a condensation there, to a changing of the time of the tune. Let us briefly consider three corollaries of this proposition. (I) Just as there are in organisms architectural variations which find expression in spatial rearrangements of materials (comparable to those we see a schoolboy effecting with his "mechano" toy, out of which he constructs now a crane and again a bridge, to-day a railway truck and to-morrow an aeroplane), so there are temporal variations which find expression in changes in the rate of growth and development, or in alterations in the rhythm or punctuation of life. In this connection it is interesting to remember that in the internal secretions (of back-boned animals at least) there is a means by which the rate of growth and development can be automatically regulated. How suggestive, for instance, is the result of Gudernatsch's experiments on tadpoles, that a thyroid diet stimulates differentiation and hinders growth, while a thymus diet inhibits differentiation and lets growth go on. (2) The general idea is that the curve of life is like a discontinuously elastic thread wth fixed arcs here and there, and that the tension 
of the several parts can be altered in adaptation to particular conditions. This is part of the tactics of evolution, and it is interesting to observe the diversity of the problems that alterations in the tempo of life are made to solve. The open-sea larval period in crabs and rock-lobster, in seaurchins and starfishes, secures diffusion and saves the delicate young life from the intolerable roughand-tumble conditions of the shore. The swimmingbell or medusoid period (sexed) in the life-history of many a sedentary asexual zoophyte or hydroid colony probably secures the advantage of crossfertilization. The very general suppression of the free-swimming larval stages in river animals (excepting cases such as insect larvæ, where gripping organs are well developed) is evidently an adaptation against the risks of being washed down to the sea or being borne into an equally fatal stagnant backwater. A telescoping of not only larval periods but of youth itself into a prolonged embryonic development may mean that circumstances are too tyrannous for delicate young lives, but it may also mean, as in many mammals, that time is given in the long antenatal life for the perfecting of a fine organization, able from birth, in many cases, to cope with the exigencies of life. Robert Chambers, the author of the once famous $V$ estiges of Creation, was surely right in insisting that the embryo's biding its time within the womb was as precious to it as it was costly to the mother. It meant bigger and better brains. In the prolonged youth, again, 
of some other mammals, especially those with a play-period, there is, as Dr. Groos and Dr. Chalmers Mitchell have so well shown, an adaptation which secures the breaking down of rigid instincts and their replacement by the remembered results of free and intelligent experiment. (3) While man is a slowly varying creature, changing but little from age to age in the organic punctuation of his life, he is eminently plastic or modifiable, and therefore able, probably to an extent unsuspected, to lengthen out his youth, to prolong his period of cerebral variability, and to shorten his senescence. In all of which there is a great hope. 


\section{$\mathrm{XX}$ \\ REJUVENESCENCE}

PRING is slow of coming to the moor of $\infty$ Dinnet, but on Ist April, I9r6, it arrived almost without warning-alighting, like some great beneficent bird, from a distance. We had gone to sleep in what seemed like midwinter; it had been the most inhospitable March for many a year; we awoke to feel the West wind coming in at the window, and the simple songs of yellow-hammers and titmice, and a new smell from the fir trees; and we knew that the winter was over and gone. Lochnagar is deep in snow, and all the little hills around are black and white, but the snow-wreaths could be seen shriveling, and there is over six feet in the river where there are usually but three. To a stranger from the South the spring atmosphere of the day would seem admirable, but he would miss the note of vital exuberance. It has come too quickly for that. There are some birds-blackheaded gulls, oyster-catchers, wagtails, for instance, at the flirtation stage; the rooks, lapwings, and larks have got past it; but there is not yet any hint of the great orchestra which will arrive by and by. We saw on our walk one lamb, one tortoiseshell butterfly, one hairy caterpillar, and less parsi- 
moniously a crowd of hive-bees very busy at the top of a wayside willow whose upper catkins are out. Apart from the catkins and the gorse (which - does not count), we saw not one opened flower. The leaf-buds were just showing on broom and briar; the twigs of the larch were gilded a little and the birch trees had put on their purple, but these were not much more than hints of the rejuvenescence that we know to be sure and certain.

The biology of spring is a book with many chapters, and it is but one chapter whose pages we would turn to-day. Spring is the time of year particularly associated with a capacity that many living creatures have of becoming young again-a capacity that Man and the higher animals have in greater part lost. The whole question has recently been brought before serious students of biology in two remarkable books by Professor W. M. Child of Chicago (Senescence and Rejuvenescence ${ }^{1}$ and Individuality in Organisms ${ }^{2}$ ), and it is a profitable subject for reflection, not least for those who have to-day good reason for finding it difficult to be as gladsome as those yellow-hammers, or as rejuvenescent as these birch trees. In the world for which Man is primarily responsible, namely, civilized mankind, domesticated animals, and cultivated plants, it is all too easy to find examples of senility-aged people who are pathetic as broken harpsichords; woe-begone, aged horses and dull-eyed wheezing

Chicago University Press, I9I5.
Ibid., 1916. 
dogs; fruit-trees smothered in lichen and rotting in their hearts. Such senility marked by degeneration or involution, by great liability to disease and by an ungearing of important parts of the organism, is practically unknown in wild Nature which has not suffered from Man's interference. Even the Sequoias with their two thousand years are not senile, and the famous Edinburgh sea-anemone, which lived longer than the average human span, did not show its age. There are two main reasons for this absence of senility in Nature; the first is that the conditions of the struggle for existence are such that senility is not tolerated; the second is that the average duration of life seems to have been punctuated in reference to wide issues, namely, the welfare of the species. Creatures come to a natural end when their processes of rejuvenescence fail hopelessly to keep pace with their processes of senescence. For to senescence as distinguished from senility the great majority of organisms are liable.

To the question, "Why do we grow old?" many answers have been given. Metchnikoff suggested that we are poisoned by the absorption of the products of bacterial activity in the large intestine, for this brings about hardening of the walls of the arteries and also corrupts our bodyguard of wandering amœboid cells or phagocytes, so that they become traitors, turning upon the cells of the central nervous system. Others have suggested other modes of auto-intoxication. To some it has seemed enough to refer to the wear and tear of hard-worked 
organs like brain and heart, liver and kidneys, for a chain is no stronger than its weakest link. Others have referred to the waning activity of the allimportant organs of internal secretion, and others to the sobering fact that there is no multiplication or replacement of the cells of our central nervous system after a very early date in our life. It may be pointed out, however, that most, if not all, of the theories break down because they do not admit of all-round application (thus it is plain that many animals that are not troubled with a large intestine nevertheless grow old), and furthermore that the theories seize on symptoms rather than on causes; for while it is good sense to refer to wear and tear, the question arises why all animals do not exhibit the perfect recuperation to which some at least have attained.

Professor Child has been working for fifteen years or more with simple creatures called Planarian worms, which he has come to know with considerable intimacy. One of the features of their life which he brought to light is their capacity for periodically becoming young again. Thus it often happens that a Planarian separates off the posterior third or quarter of its body, which speedily grows into a whole, while the diminished original heals itself and grows a new tail. This is an old story, but the new fact is that in the reconstitution of the whole from the part there is a remarkable process of rejuvenescence. Instead of the current of life being slow, it is very rapid; the output of 
carbonic acid (a common index of the rate of metabolism), as measured by Tashiro's delicate "biometer," is greater than usual; and the piece is less susceptible and more resistant to poisons like cyanides than when it was part of its parent. If these be qualities of youth, then this regrowing fragment is again young. Similarly, when a Planarian is starved, it can continue living on its own resources for several months. Its cells become smaller and they also become fewer, but life is not surrendered. This, again, is an old story, but the new fact is that the starveling becomes curiously young-a quaint biological justification of asceticism-it is almost born again. Such facts have led Professor Child to a survey of the animal kingdom, the result of which is to show that there is a much wider occurrence of rejuvenescence than has been hitherto realized. It occurs especially in connection with vegetative multiplication, but there are other occasions in which de-differentiation sets in, and the creature becomes younger in whole or in part by lying low for a season. Perhaps this may be part of the value of processes of dying-back and rearrangement which occur in winter in some animals and in many plants.

Senescence is an all but universal retardation of the rate of life, a diminution of vigor and resisting power, and there can be little doubt that Professor Child is right in regarding it as the necessary consequence of accumulation, differentiation, and other stereotyping changes in the colloid substratum 
which forms the framework of the chemico-physical basis of life. Chemically regarded, living means the co-ordination of characteristic chemical changes, differing in nature and in rate in different creatures and in different parts of the same creature; but as these proceed they form a colloid framework in which they work. As the complexity of the framework increases, and the stability of the organism, so, too, the effectiveness of its chemical reactions. Thus the earthworm is more of an agent than the amœba, and the bird more than the earthworm. But the nemesis is senescence-the tax on stability, and rejuvenescence is the attempt at evasion. In the Protozoa, as Weismann and others have pointed out, the recuperative processes are so perfect that natural death need never occur; the stable mortal parts of the colloidal substratum can be reduced and restored piecemeal, and the creature never grows old. It is probable that the same is true of a simple animal like the freshwater Hydra, which may also be credited with immortality. But as life became more worth living, and the organisin more of an agent, it became more and more difficult for the processes of rejuvenescence, which are always going on, to keep pace with those of senescence, which, to tell the truth, may begin before birth! Then it became necessary to have special periods for rejuvenescence, "spring-cleanings" of the organism, and we see these in the de-differentiations and new beginnings associated with budding and the like, perhaps even in such striking phe- 
nomena as the return to an almost embryonic state that we are familiar with in the pupa-stage in the life-history of flies and some other insects with complete metamorphosis. But what of the distinctly higher animals and man himself, where there has been an epoch-making evolutionary increase in the physiological stability of the protoplasmic substratum and an associated heightening of the degree of individuation? The central nervous system in particular limits the capacity for rejuvenescence. "For his high degree of individuation man pays the penalty of individual death, and the conditions and processes in the human organism which lead to death in the end are the conditions and processes which make man what he is." Professor Child has an interesting speculation, in support of which some experimental evidence is adduced, that the very early pre-differentiating stages of embryonic life in some complex organisms, where the individual certainly fails to evade senescence, may afford opportunities for rejuvenescence at the very start of life-for lessening the risk, that is to say, of hereditary stereotyping or of being born old. We should think that there were many opportunities for this sort of reorganization at the beginning of every new life that develops from a fertilized egg-cell. But of an elixir vitz for the individual there seems little prospect. "The advance of knowledge and of experimental technique may make it possible at some future time to bring about a greater degree of rejuvenescence and retardation of senescence in 
man and the higher animals than is now possible, but when we remember that the present condition of the protoplasmic substratum of these organisms is the result of millions of years of evolutionary equilibration, we cannot but admit that this task may prove to be one of considerable difficulty."

We should just think it will, but we are slow to conclude that we must simply say as of old: "And so from hour to hour, we ripe and ripe; and then, from hour to hour, we rot and rot." For in the biological facts we find more than a hint that changes are lightsome; that habituations age us; that new work, new scenes, new play, new rest, at the worst new diet, should be experimented with; that we should cultivate in our pilgrimage the adventurous mood, for if it be true that a man is just as old as his arteries, it is also true that he is as young as his mind is. Our life is, we suspect, largely punctuated beforehand, but certainly not wholly. We can put in commas, and we have a sporting chance of inserting semicolons. In any case, our effort to stave off senescence is likely to be rewarded by an evasion of senility. 


\section{XXI}

\section{THE BIOLOGY OF TWINS}

THE path of light is often strangely circuit1 ous, for who would have thought that the study of an armadillo would illumine the problem of human twins? That this is so has been vividly shown by Mr. Horatio Hackett Newman in an entertaining volume entitled The Biology of Twins. ${ }^{1}$ One cannot help envying him the story he has to tell. Not uncommon in Texas is an old-fashioned creature, the Nine-banded Armadillo, a sort of living fossil belonging to a stock unique among mammals in having bony plates in its skin. Between an arched cuirass over its shoulders and a similar shield over its loins it has nine movable bands of bony armor. The body is about eighteen inches in length, not counting the pointed armored head with mulish ears and the long tapering tail. Baskets made of armadillo carapace with the tail arched over to form the handle are common curios in the New World. The creature is mainly insectivorous, and hunts at night, retiring to its deep six-foot burrow during the day. Its armor is defensive against the thorns and spines of the arid vegetation amongst which it lives, and stories

${ }^{2}$ Chicago University Press, 1917. 
of the armadillo rolling up into a ball (a prerogative of the Little Armadillo) "are totally inapplicable to this species, for the animal turns over on its back and kicks viciously and effectively with its powerful and heavily armed feet." But beyond noting that the young ones are born well advanced and able to walk about within the first few hours, we must not say anything more about the natural history of the Nine-banded Armadillo. For our present purpose the important fact is that this quaint creature normally and habitually produces quadruplets-a remarkable fact which several zoologists have studied, and Mr. Newman most thoroughly of all.

Many mammals, such as rabbits, produce numerous young ones at once, but each of these develops separately from an egg-cell, and the phenomenon of multiparous birth has nothing to do with twinning. That term is appropriate when a creature normally uniparous, such as cow or bat, gives birth simultaneously to two offspring. As every one knows, these may be quite dissimilar, or they may be living images of one another, in which case they are always of the same sex. In untoward cases twins may be physically continuous, as in the "Siamese twins," and one member of the pair may be to a varied degree degenerate or undeveloped,- - the result being the twin-monsters of the show or of the embryological museum. Some of them are the results of fission, others of fusion. But there has been much vagueness and uncertainty 
about the whole subject of twinning, and we welcome the light that has come from the armadillo.

Mr. Newman's investigations have made it quite certain that the quadruplets of the Nine-banded Armadillo are all simultaneously produced from one egg, within a common birth-robe, and that they are always of the same sex. In a neighboring species, the Hybrid Armadillo, believed to be a recent evolutionary derivative of the Nine-banded, the number of "polyembryonic offspring" developed from one egg varies from seven to twelve, with a tendency to settle down to eight-a variability which suggests that the peculiarity in question is of comparatively recent origin.

When the egg of the lancelet at the two-cell stage is shaken vigorously in the sea-water in which it floats, the two cells separate and form two half-sized embryos and larvæ. If the shaking is less vigorous, so that the two cells do not go apart, Professor E. B. Wilson found that Siamese-twin embryos are formed. Similarly from the four-cell stage he got four dwarf embryos and larvæ, or queer non-viable Siamese quadruplets! In some Ctenophores or sea-gooseberries, twinning is often noticed after storms, for the first two cells of the segmenting egg are shaken apart. But it is not by the dislocation of the first four cells that the quadruplets of the Nine-banded Armadillo arise. What happens is that in a single embryonic vesicle formed by the segmentation of the fertilized egg-cell, and after considerable differentiation has occurred, four 
secondary growing-points experience, for some reason or other, physiological isolation, and proceed to develop in independence. It is known that injections of butyric acid and some other reagents into fish embryos may bring about a sort of dislocation or partial dissolution of the germinal area, and that this "blastolysis" results in monstrosities. As butyric acid may arise in a mammal's body as the results of deranged carbohydrate metabolism, Werber has suggested a physiological theory of the origin of certain kinds of monsters. Now it may be that the slight isolation or insulation of four foci in the germinal vesicle of the armadillo is a step in the direction of blastolysis which has not, however, crossed the limits of the normal. It may also be, as Mr. Newman suggests, that the development of two offspring from one egg is "only a phase of the much more general phenomenon of symmetrical division." Thus the building up of the right and left sides of a bilaterally symmetrical animal is essentially a twinning process. It is a very interesting fact that of twin-brothers one is sometimes right-handed and the other left-handed.

In the Nine-banded Armadillo quadruplets spring from one egg, but it is a curious fact that in the Hairy Armadillo (Euphractus) twins arise from two eggs whose external birth-robes (chorionic fœtal membranes) fuse together secondarily. Needless to say, these twins may be of different sexes, while the quadruplets of Dasypus are always of one sex. Here, then, we have an instructive hint of 
what doubtless occurs in man; duplicate or identical twins develop from one egg; dissimilar or fraternal twins develop from two separate eggs. Outdoing the poly-embryony of the Nine-banded and the Hybrid armadillos is that of some Hymenopterous insects (e.g. Litomastix) which lay their eggs in caterpillars and the like, for from each egg there develops a legion of embryos. One would like also to speak of the twinning of a common earthworm, which seems to occur most frequently in warm weather, a fact to be taken in conjunction with the experimental result that the eggs of some sea-urchins often twin in large numbers when the water is artificially warmed. Fascinating in its way, but taking us into rather deep waters, is the case of the "free-martin," a sterile and abnormal female calf showing some masculine features which seem to be due to hormones borrowed from its male co-twin, the two of them arising, undoubtedly, from two egg-cells.

Another point of great interest in the biology of twins was raised long ago (1876) by Mr. Galton, ${ }^{1}$ who sought to find in the history of twins a criterion of the relative powers of " nature" and "nurture." Will duplicate twins become unlike if subjected to diverse nurture? Will dissimilar twins become more like one another if subjected to the same nurture? Mr. Galton investigated about eighty cases of close similarity between twins, affecting color of hair and eyes, height and weight, strength

${ }^{1}$ Journal of Anthropological Institute, 1876. 
and temperament, intonation and handwriting. It may be both interesting and useful to recall some of the extraordinary illustrations of the close resemblance of duplicate twins, developed, as the armadillo story makes clear, from one egg. Mr. Galton tells of a case in which no one, not even the twins themselves, could distinguish their handwriting; of another case in which "a doubt remains whether the children were not changed in their bath, and the presumed A is not really $B$, and vice versa"; of two girls who used regularly to impose on their music teacher, one of them taking two lessons in succession when the other wished a whole holiday; of a schoolmaster who, to make sure, used to flog both twin-brothers when one had sinned; of nine cases where a twin addressed his or her reflection in a mirror in the belief that it was the other twin in person; of four or five cases of doubt during an engagement of marriage; and of a quaint interchangeableness of expression, "that often gave to each the effect of being more like his brother than himself." The depth of the constitutional sameness is said to be sometimes seen in the twins sharing some special ailment at the same time or showing the same exceptional peculiarity. "Two twins," Galton noted, "at the age of twenty-three were attacked by toothache, and the same tooth had to be extracted in each case." Two closely similar twin-brothers, of similar tastes and profession, died of Bright's disease within seven months of each other. Sometimes the resemblance is 
subtle as well as thorough. "One twin, A, who happened to be in a town in Scotland, bought a set of champagne glasses which caught his attention, as a surprise for his brother B; while, at the same time, B, being in England, bought a similar set of precisely the same pattern as a surprise for A." The price paid was doubtless precisely the same. The question which particularly interested Mr. Galton was how far diversity of environment and occupation affected twins who showed, to begin with, very close similarity. In some cases "the resemblance of body and mind continued unaltered up to old age, notwithstanding very different conditions of life" ; in other cases there was divergence usually traced to some form of illness affecting one of the twins, and this may have implied an initial difference which escaped detection. Nature is stronger than nurture. On the other hand, Mr. Galton found that twins which did not at first show "close similarity" did not become any liker one another after prolonged influence of similar nurture. "There is no escape from the conclusion that nature prevails enormously over nurture when the differences of nurture do not exceed what is commonly to be found among persons of the same rank of society and in the same country." The cuckoo's note is not affected by its early instruction in the language of its foster-parents. It should be carefully noticed, however, that some very striking cases are on record-e.g., in the late Mr. Benjamin Kidd's Science of Power (1918) - of birds and 


\section{THE BIOLOGY OF TWINS}

mammals which were kept from earliest youth in peculiar conditions of artificial nurture and took on the ways and habits of their unrelated comrades; that many cases are known among children where those transplanted early from deteriorative to wholesome conditions have developed well; and that the changes of nurture in Galton's cases were within very narrow limits. Hereditary "nature" is indeed the seed-corn; nurture is the sunshine and the soil, the wind and the rain. When both components of a resultant are essential, it does not seem to matter very much which we call the more important. The fundamental factors of all sorts of characters are in the germ, but the precise expression they find in development depends in some measure on the nurture. 


\section{XXII}

\section{A LIMB FOR A LIFE}

MONG the many effective ways in which A animals parry the thrusts of Death, is there one more daring than what is called autotomy - the surrender of a part which often saves the whole? Seemingly daring, one must say, however, for all the typical cases of self-mutilation are nowadays reflex, occurring quite apart from any deliberate intention to sacrifice intactness for existence. A starfish, seized by one of its arms, surrenders this to the captor and escapes with the other four, regrowing the missing part at its infinite leisure. But since the starfish has not a single nerve-ganglion in its body, no one can credit it with having reflectively recognized that it is better that one member should perish than that the whole life should be lost. That the surrender of an arm is effective is certain; that it now happens reflexly is also certain; but to conclude that this interesting kind of response to a frequently-recurring risk was historically established without any glimpse of awareness on the creature's part is premature. We have to remember, for instance, that brainless and ganglionless as the starfish is, it shows, e.g., in its combat with a sea-urchin, a capacity for per- 
sisting in a prolonged endeavor along a line which is certainly not that of least resistance, which leads to a reward not immediately, but only eventually.

Perhaps Nature would not have put her natural selection stamp of approval on the asteroid's autotomy if individual starfishes had not approved of it themselves. We are not prepared indeed to say what form the brainless creature's approval might take, but we get an indication of it perhaps in approvals given by our subconscious self. Quite in the opposite direction is another saving-clause, that cases of a rat or a stoat cutting itself free from a trap by amputating a limb, belong to a category different from and higher than that of starfishes or crabs which illustrate typical autotomy.

The highest level at which autotomy is practised is among lizards, many of which need but little provocation to induce them to surrender their tail to their assailant-an expedient that often saves their life. The specific name of our British limbless lizard (Anguis fragilis) registers the uncanny readiness with which it surrenders the tail of its snakelike body. That lizards have taken ages to bring their life-saving curtailment to perfection seems probable, especially when we notice that in many forms there is a special breakage area, and that a weak line has been established affecting skin, muscles, connective tissue, and backbone. Up the middle of the vertebra there is a soft zone, the breakage plane, across which the tail snaps in the autotomy. What is lost by the amputation can 
be regrown at leisure, though not with the original finish. Newts and salamanders (and the tadpoles of frogs and toads) have great powers of regrowing parts that have been bitten off, but, so far as we know, lizards are the only backboned animals that show autotomy. The phenomenon is seen again among mollusks, not a few of which give off pieces of their body. There is the very curious case of many male cuttlefishes which give away an "arm" in marriage-the discharged member being described by some old zoologists as a separate creature called "Hectocotylus." This instance should perhaps be kept by itself, but it shows that the capacity of surrendering parts can be utilized towards various ends.

Some zoologists have tried to restrict the term "autotomy" to the surrender of what should normally be retained, but it does not seem practicable to maintain this strict usage. Many of the sea-slugs, like Tethys, though captured ever so gently, proceed to disembarrass themselves of fingerlike processes on their back-strange sops to Cerberus. Many worms also show a strong tendency to self-mutilation when they find themselves in the unusual conditions of capture. One throws off its tentacles, another its pharynx; one offers you its head and another its tail. We look on with helpless chagrin while a fine specimen of a ribbon-worm, say Cerebratulus, lying unharmed in a basin of clean sea-water, breaks with strong muscular contractions into inch-long pieces. There may be some intense 
disturbance of metabolism which we do not understand; or it may be that we are simply witnessing an extreme tetanic exhibition of what occurs in a less drastic way in ordinary life and with life-saving results. For minor losses are soon made good and parts may become wholes. In many simple worms the periodic surrender of a posterior piece is a regularized mode of multiplication; in the Palolo worm, which burrows in the coral-reefs, nearly the whole of the body is broken off at the breeding season and bursts in the water, liberating tens of thousands of germ-cells, while the head remains in the rock and makes a new body by and by. Among starfishes, brittle-stars, feather-stars, and seacucumbers there is an extraordinary prevalence of autotomy. A starfish may jerk off each of its five arms seized in succession; it may cast off an injured or parasitized arm; in rare cases there is multiplication by division. Sea-cucumbers discharge their viscera in the spasms of capture and may thus escape from an astonished foe. The replacement of the food-canal is sometimes accomplished in ten days, though it may take as many weeks. The heart-urchin often gives off its snapping spines when they nip the skin of some molester.

One often sees among the stubble very interesting, somewhat spider-like creatures called harvestmen (Phalangidæ), which move swiftly (in the evening especially) on extraordinarily lank legs, over twenty times the length of the body. They hunt mostly by night, killing and sucking small insects and 
drinking drops of dew. If we catch one by the leg it surrenders it instantaneously and stalks away. The same sort of profitable autotomy is exhibited by some spiders and by some insects, such as grasshoppers, crickets, and their relatives. A quaint case is that of the Termites, or white ants, which shed their wings when they settle down, after their so-called "nuptial flight." The amputation in all these cases is rapid and reflex, and there is no bleeding. But precise knowledge of the physiology of autotomy is far to seek except in the case of the higher Crustaceans, to which we shall now pass with special reference to the recent work of Mr. J. Herbert Paul. ${ }^{1}$

(I) It has been recorded in regard to a common amphipod Crustacean, called Gammarus, that if a leg be injured the animal bites it down to the basea quaintly deliberate autophagy. (2) If a prawn's leg be violently seized, the animal gives a vigorous jerk with its tail and the leg breaks off at the base between the second and third joint. If the breakage fails, the prawn may be seen to tug at the limb with its jaws, thus harking back towards autophagy. (3) If the leg of a lobster or crayfish be seized, it always breaks at the level of a groove in the third basal segment. There is a definite breaking-plane. Moreover, before the animal strikes with its tail, a muscle in the third joint weakens the limb at the level of the breaking groove by pulling inwards

${ }^{1}$ Proc. Royal Soc. Edinburgh, xxxv. (1918), pp. 78-94, 4 plates, and pp. 232-262, 29 figs. 
parts of a ring of calcareous integument. The amputation is more complex and more effective. The autotomy does not work unless the limb be gripped, but in some cases, again, the animal may pull off a damaged limb with the help of one of the clawed appendages. (4) In hermit-crabs, which shelter their soft tail in a borrowed Gasteropod shell, a damaged limb is amputated simultaneously with the withdrawal within the sheltering shell. A message travels to the nearest ganglion of the ventral nerve-cord; an answer comes back commanding violent muscular contraction at the base of the leg; and in a moment the limb is severed. But it is very interesting to find that a hermit-crab upset by being removed from its borrowed shell may pluck at an injured limb with its forceps, or may even bite it down to the breaking-plane, thus falling back on autophagy. (5) It is in crabs that the autotomy reaches perfection. There is a definite breakingplane, a line of weakness, across' the second basal joint; the breakage is due to the forcible antagonism of muscles working at this plane; the snap occurs before one has time to say "self-amputation."

In the shore-crab and the edible-crab the limb cannot break off unless the distal part of it be pressed against something, such as the animal's own shell or a stone; in the swimming-crab and the sand-crab even the point d'appui is dispensed with. But perhaps the neatest adaptation in crabs is the diaphragm or bandage-membrane which stretches 
across the interior of the hollow limb at the breakingplane, leaving a foramen for nerve and artery. This diaphragm consists of two flaps, and when autotomy occurs "these are forced together by relative change of pressure on the outer side." They act as a valve, "and the moment autotomy takes place bleeding is stopped." We feel ourselves in the theater of a great surgeon whose knife staunches as it cuts. We are reminded also of the partition which in autumn grows across the insertion of the leaf-stalk and closes the wound as it separates off the withering leaf.

We see, then, that the surrender of a limb is of common occurrence in higher Crustaceans. It often secures escape; it also avoids bleeding to death if a limb has been badly wounded by an enemy or bruised by the movement of stones on a stormswept shore. We find, moreover, that it sometimes occurs rather roughly and sometimes with great neatness; that it sometimes involves several acts in a chain and sometimes only one. And the very interesting general result reached by $\mathrm{Mr}$. Herbert Paul's fine experiments is that in those higher Crustaceans, such as crabs, where the breaking joint is structurally most complex, the physiological reflex process is simplest. It is a single reflex, whereas in lower forms there may be several links in the chain of events. In the crab, as he says, there has come about in the course of time a shortcircuiting of a "current" which in lower forms has a much longer path. Such occasional returns 
to autophagy as the hermit-crab exhibits seem to us to corroborate our suggestion that we must not conclude from the simplicity of a present-day reflex that the process has evolved without any factor of awareness.

What is the evolutionist's finding-provisional, of course-in regard to the problem of autotomy? Perhaps this: (I) that a capacity for breakage is very widespread among the less integrated lower animals; (2) that it may have to do with increase in size beyond the limits of nervous control, or with an inequality in the intensity of metabolic processes in different parts of the body; (3) that the giving off of parts may be useful as a mode of vegetative multiplication; as a means of getting rid of an aged, injured, or parasitized portion; and as a way of escaping from enemies; and (4) that it has come to be associated with a subsequent regeneration of what has been surrendered. Given these materials, so to speak, and plenty of time and sifting, the organism can perhaps work out structural elaborations as finished as those in the crab. But it is at least a tenable theory that the organism is a purposive individuality as well as a co-ordination of chemical reactions taking place in a colloid substratum, and that from time to time the factor of endeavor and the will to live has entered into the evolutionary process with varied degrees of self-awareness. It is conceivable also that what in some cases required to begin with-it may have been for a million years-genuine behavior, the con- 


\section{SECRETS OF ANIMAL LIFE}

trolled co-ordination of a chain of activities, so that they lead to an effective result, may in the course of time be short-circuited and sink to the plane of reflexes, leaving the organism disembarrassed and free for fresh adventure. 


\section{XXIII}

\section{LATENT LIFE}

W ${ }^{H E N}$ a saucer of paste is left forgotten on a shelf it becomes the soil for an abundant growth of minute fungoid plants or molds. But in many cases it also shows a population of "paste-eels," transparent microscopic threadworms, the germs of which have been wafted into the saucer by air-currents. Millions of the closely related "vinegar-eels" are sometimes to be found in vinegar-cruets which have been left uncorked. The worms seem to thrive in that strange habitat, and they make the vinegar turbid with their multitudes. Now, the paste-eels and vinegar-eels (and other "Anguillulid Nematodes") are noteworthy for their capacity for latent life. They can remain dried-up, without signs of any activity, for years, and yet become lively again when restored to moisture and other appropriate conditions. It seems that some of them can endure the "suspended animation" for fourteen years, and that the time required for revivification is proportionate to the duration of the latency. The eel worm which causes "ear-cockles" in wheat is able to lie latent in its gall for over twenty years. The same phenomenon is illustrated by some mites, 
by those species of "water-bears" that live in moss, by many wheel-animalcules or rotifers, by some of the minute Crustaceans known as water-fleas, and by some still simpler animals. In some cases what endures is the whole creature as such; in other cases it may be a cyst formed inside the animal, or, it may be, just an egg with a resistant shell. From dried mud taken from a pond and kept in a box for ten years, one can by putting a sample into water rear many little creatures. Professor Giard found that the eggs of the large freshwater Crustacean called Apus could survive twelve years of drought. Some Protozoa dried on paper were revived after five years. It is difficult, no doubt, to draw a strict line between these cases of latent life and other conditions of lying low, as in the true winter-sleep or hibernation of hedgehog and dormouse, or the winter-torpor of the frogs in the mud of the pond and the snails in the recesses of the old wall, or the lethargy of some fishes that encapsule themselves in the mud during the dry season and suddenly reappear when the rains return; but what marks off latent life in the stricter sense is the desiccation of the organism and the entire absence of any positive signs of "life." The question is whether the activities which we sum up in the word "life" have come to a standstill, or whether the fire is still burning, but very low? We cannot dissociate activity from our idea of life, but here is an organization so dry that it is brittle, in which we can detect no movements, not even chemical 
changes, and yet it is not dead. For in a few days we may revive it into vigor, or may nurse into lively development the cyst or germ which it incloses. The riddle stares us in the face in every bag of dry seeds. In what state is the life of these seeds, for most of them are alive in this sense at least, that they can in appropriate conditions give rise to living plants? This brings us to consider the remarkable experiments recently made by $M$. Paul Becquerel.

One of the first results of Becquerel's work was the demonstration of the extraordinary impermeability of the envelopes of many seeds. Thus the coats of the naturally dried seeds of the lupine remain impermeable to air and other gases for two years. They are also impermeable to liquids, such as absolute alcohol, ether, and chloroform. The gases and liquids readily soak into seeds of lupine, peas, and beans whose coats have been taken off, but when the coats are left on they are for a long time gas-proof and liquid-proof. Very careful experiments with naked seeds of peas, beans, and lupine, in their natural state of dryness (that is, still containing a minute quantity of water), showed that after a certain time in darkness they absorb traces of oxygen and liberate traces of carbon dioxide. But this gaseous interchange is probably due to a simple chemical oxidation at the surface of the seed and not to an attenuated respiration. It is certain that seeds do not necessarily lose their power of germinating though they have been kept 
for months in conditions where no respiratory exchange with the outer world was possible. Becquerel showed that seeds deprived by an airpump of their internal atmosphere and kept for a year under mercury, or in nitrogen or carbon dioxide, or in a nearly complete vacuum, still retain their power of germinating. IVhat is this life that sulks and hides itself, but will not die? Life is a kind of activity, a series of correlated reactions among the members of a well-constituted chemical firm, and taking place in what is called a colloidal substratum which is to the essential activity of the protoplasm as the bed of a river to its flow; but the activity can only occur in an appropriate environment of air and moisture and the like. So the question is, whether the latent condition implies a total suspension of vital activities, or " an extremely sluggish, intracellular, anærobic life?" There is a blockade, but does the firm entirely suspend operations, or does it keep going in a small way, which we cannot detect?

The great French physiologist Claude Bernard, to whom we owe the term "latent life," maintained, in his classic work on "The phenomena of life common to plants and animals," that life is a relation between organism and environment, and that in dry seeds and desiccated animals it is only potential. "It exists ready to manifest itself if appropriate external conditions are available, but there is not the slightest manifestation of it if these conditions are lacking." Living is not attenuated 
in the dry.seed; it has stopped. The seed is like a watch, stopped but not run down, which a shake might set going again. This view leads one to the reflection that if latent life is an entire suspension of protoplasmic functions, then the period during which revivification is possible should admit of great extension. Now when we inquire into the facts we find that the limits are not usually very long. This suggests, at first sight at least, that what has happened has been an extreme slowing down, not a stoppage of the vital processes or metabolism. Some of the dried Anguillulid worms will not revive after fourteen years, and others not after twentyone, and there are limits with seeds also. The Sleeping Beauty cannot sleep indefinitely. That distinguished Egyptologist M. Maspero never succeeded in germinating the grains of wheat which he collected in the tombs of the Pharaohs, though frauds practised on the inexpert yielded surprising results. Becquerel's careful experiments showed that some seeds may germinate after resting in a herbarium-a hortus siccus indeed-for eightyseven years, but the tenure of latent life is in most cases much more limited. Twenty germinations were got from seeds from twenty-eight to eightyseven years old, but most were towards the lower figure. Even very tough seeds, which Ewart has called "macrobiotic," do not keep their germinative power much beyond a hundred years. In many cases among plants and animals the limit of latent life is a few years. This seems against Claude 
Bernard's view that vital activity is wholly suspended, for why should there be a limit, if this be so? It is quite likely, however, that the limit is determined not by the potency of the essential protoplasm, but by the endurance of the colloidal substratum - the furnishings of the chemical laboratory. The spring of the stopped watch might in the course of time undergo some molecular change which robbed it of its elasticity, so that no shake would set the works going again. Something analogous may occur in the desiccated organism.

The recent experiments clearly show that subjection to conditions utterly hostile to the persistence of the most attenuated of vital processes or metabolism is not necessarily fatal. Macquenne kept parsnip seeds for two years in a vacuum, and made them as dry as dry could be, yet they were still able to germinate. Indeed, they retained their sprouting power for a much longer time than control seeds kept in the open air. The same conclusion is suggested by similar experiments made by Becquerel and also by the results of subjecting seeds to very low temperatures. Using the refrigerating laboratory or "cryogen" of M. Kammerlingh Onnes at Leyden, he subjected naked seeds of lucerne, mustard, and wheat for three weeks to the temperature of liquid air, and then for seventyseven hours to that of liquid hydrogen at $25^{\circ}$ below zero. The seeds were then put into a vacuum for a year. Under the combined influence of low temperature and desiccation, the protoplasm lost 
its state of colloidal solution, but, in spite of all, the seeds showed a high percentage of germination! Now, as Becquerel says, "life without water, without air, without gaseous exchanges, without colloid molecules in suspension in a liquid, appears paradoxical." The vital current is frozen hard, and if this be so we are forced to the conclusion that life is not bound to be quite continuous until death overtakes it. It can stop and begin again. It is not to be supposed that the composition of that chemical firm which we call protoplasm has been altered, or that any of the component molecules have suffered disintegration. That way death lies. But there has been a physical check, like the freezing of a stream, from which recovery is possible within limits. One would like to see Becquerel's experiments extended to the animal world, where the phenomena may be different; but the evidence from seeds points to the conclusion that life may be interrupted without destroying its power of resuscitation.

As Becquerel points out, the capacity for lying low is no mere curiosity, it has significance in the struggle for existence. It enables organisms to bide their time, to bend to the storm, to wait and see. Many minute creatures get carried about in a state of latent life; others rest in quietness, evading a hopeless struggle, and if propitious conditions are restored in time, they do not lose their reward. "Latent life is a true Providence for the terrestrial conservation of organisms." Becquerel suggests 
that if the sun were extinguished and all the gases of our atmosphere disappeared, seeds and germs, eggs and spores of organisms, in the state of latent life, might linger on for a long time on the surface of the "frozen, uninhabitable planet, wandering in the darkness of cosmic space." It is possible that under the influence of the radiations of a new system the frozen streams of protoplasm might thaw and flow again; it is possible that a shattering of the derelict by collision or explosion might sow new worlds with the seeds of old life. 


\section{XXIV}

\section{THE STORING INSTINCT}

7 HERE are various ways in which animals 1 meet or circumvent impending seasonal scarcity. Many go into winter quarters, and. reducing their expenditure to a minimum, lie low till the spring calls them again to action. Others, like the wolves, continue to live dangerously, and simply intensify the keenness of their hunting. Some, like the ermine and the ptarmigan, don a white dress, which is not onlly physiologically best for warm-blooded creatures in very cold weather, but gives them a garment of invisibility against the background of snow. Others solve the problem by a change of habitat-notably the migratory birds, which come from the snow-covered moors to the open shore and the fields adjacent, or "wing their way from cloud to cloud down the long wind" to "warmer lands and coasts that keep the sun." There are several other solutions of the problemto curl up and die is to decline to consider itand one of these is to lay up stores, to hoard, to save. Many animals do this inside their bodies, and what are called " hibernating glands" and the like are internal stores for the evil day, but we shall confine our attention to external savings. 
A highly specialized storing routine like that of hive-bees always gives one at first an impression of the inexplicable-even magical. It is wiser to start from much simpler collecting industries, for an elaborate instinctive capacity is probably the result of adding on one embellishment after another to a broad commonplace foundation, of carrying on to a fine issue a kind of behavior which in its rudiments is shared by many. A beginning of storing may be looked for, perhaps, in activities like those of earthworms, which collect leaves and drag them down into their burrows, at once making these more comfortable and providing a supply of food for the rainy day. It is surely the acquisitive habit that they have, these earthworms, for we got more than fourscore leaflets from one burrow, and we have often seen feathers as well as leaves being taken underground. We would suggest that one of the roots of the more specialized storing activities, which have a definite reference to an on-coming scarce time, is to be found in a generalized acquisitiveness like that of the earthworms, whose importance Gilbert White and Charles Darwin were at one in recognizing.

It is among insects, however, that we find an inclined plane of storing activities that lead eventually to the climax illustrated by hive-bees and by some of the ants. Many visitors to the Mediterranean region have admired the industry of the scarabees who roll marble-sized balls of dung to their holes, and there gnaw at them continuously till all 
is consumed. In this there is, indeed, only the first stage of storing, but the late M. Henri Fabre described in his inimitable way how the mother scarabee molds a pear-shaped mass and deposits at the narrow end an egg which occupies a special hatching chamber and has beside it a special first meal for the emerging grub! Here it is not difficult to imagine the step from collecting for self to collecting for others, and a great interest is attached to Fabre's observations of the Spanish Copris and some related dung-beetles which are unique among nonsocial insects, inasmuch as the mother survives to see the emergence and complete metamorphosis of the family (a very small one) for whose early sustenance she has industriously stored. It seems to us reasonable to suppose that this represents an old-fashioned state of affairs, and that the ordinary occurrence (that the mother, among the higher orders of insects, does not survive to see her young in the perfect state) is a secondary punctuation of the life-history.

There is an evolutionist.gratification in studying the storing activities of bees, for they are exhibited in such varied degrees of elaboration by different types. Among the solitary bees the mother makes a store for the brood which she never survives to see; among humble-bees the store is begun by the mother but continued by her worker-children, and there are species (beyond British bounds) in which at least a part of the society survives the winter: in tropical species of the bees generically 
called Melipona and Trigona there are permanent societies but with imperfect combs; in the hivebees we have to do with permanent societies and with perfect combs. The elaborate storing, carried to abnormal exuberance under man's domesticating tutelage, is correlated with surviving the winteri.e. with permanence, and with the survival of the mothers after the adolescence of their offspringi.e. with the possibility of social tradition. The transition from purely domestic storing to social storing illustrated by the bees on the instinctive level is closely paralleled by what has happened in mankind on the intelligent level.

It is impossible to think of storing without a vision of Solomon's ant "which, having no guide, overseer, or ruler, provideth her meat in the summer, and gathereth her food in the harvest." And, as among bees, we find all grades among ants from those that do not store at all to those that make a fine art of it. But every naturalist must put the brake on when he begins to descant on the pismires, and we shall confine ourselves to one illustration. According to recent studies of the common Mediterranean ant, Aphonogaster barbarus, the seeds which are collected are kept for a time dry and are eventually put out in the rain so that they begin to germinate. This has the advantage of bursting the hard seed-coats, and in some cases of starting processes of fermentation. At a certain stage, however, the ants kill the embryo-plant by biting off the radicle or other parts, and the seeds are dried again in 
the sun. According to Neger the dried seeds, of some leguminous plants for instance, are then taken back into the nest and chewed into dough. This is dried once again in the sun in the form of little biscuits, which are eventually put into the cupboard. It is probable that different kinds of seeds receive different treatment, and in some cases it seems that the stored material is not eaten after all, but is used as a culture for molds (e.g. Aspergillus niger) of which the ants are very fond. It is a very interesting fact that a utilization of fungoid growths-remotely comparable to man's mushroom beds-is exhibited by a number of quite unrelated animals-namely, by certain ants, termites, beetles, and mites.

Among backboned animals it is difficult to find convincing instances of storing until we come to birds and mammals. Apart from the numerous birds that store food in their crops, sometimes so exuberantly that they cannot fly, there are some that may be said to lay up nutritive savings outside of themselves. The large Eagle Owl, which occasionally visits Britain, often gathers a huge superfluity of food (including hares and rabbits, poultry and pigeons) for his mate and offspring; and peasants have been known to utilize him as Elijah his ravens. There is an old tale that ptarmigan make stores of buds and berries beneath the snow, but there is no doubt that at least two species of woodpeckers store acorns, sticking them firmly into holes which are bored "for the purpose" in the 
tree stems. This is all the more interesting if it be true that what the woodpeckers really eat is not the acorn but a kind of grub that develops inside it.

Not a few mammals are in the habit of hiding away surplus food, and it is easy to imagine how this might lead on to a more definite storing instinct such as squirrels exhibit. In a number of different hoards the squirrel hides hazel-nuts, beech-nuts, and acorns, and these may be a stand-by in the hard times of winter when the beautiful creature, who is not a true hibernator, is unable to sleep away its hunger, or when the young ones, who remain for a long time in the company of their parents; plead for food. In some mild parts of the country the squirrel's storing instinct seems to remain undeveloped. There are other mammals, such as the marmots, who make their burrows comfortable with grass and shut the door when winter knocks; it is again easy to see that this might lead on to a definite hoarding of food supplies. Such hoarding is well illustrated by some of the light-sleepers, such as dormice, who awaken from their hibernation whenever the weather is mild and are then inclined to have something to eat. In the burrow of the hamster several store-chambers are made, and grain, as well as hay, is accumulated in considerable quantity. We read that the people of Kamschatka rob the granaries made by one of the voles (Microtus aconomicus), and that the Mongolian herdsman brings his cow in autumn to eat the haystacks which are so diligently built in the summer months 
by the quaint tailless hares. IVe have not been able to verify in the field what has been circumstantially described, that moles make collections of decapitated earthworms-a store for days when the ground is gripped by unusually hard frost. We are told that these collected earthworms form a living larder, unable (as they could in summer) to regrow their lost heads, and therefore unable to crawl away. As moles are experts in dealing with earthworms and as decapitation interferes with coordinated movements, there is nothing incredible in the story. But it is a grim one!

We have seen, then, that at many different levels in the animal kingdom a storing instinct has developed. When we turn to man, pre-eminent among creatures, we find very little evidence of any such instinct. This seems the more remarkable since in North Temperate countries prevision of and provision for seasonal scarcity must have been for untold ages of life-saving importance. It is possible that the habit of saving and storing was sustained from generation to generation by a domestic tradition which has gradually become enfeebled as industrial life, facilities of transport, and communal storage made man in great measure independent of local and temporary scarcity. The duty of saving and storing was gradually shifted from domestic to social shoulders. As one would expect, the domestic tradition is stronger to-day in rural than in urban conditions, for the man with a multitude of diverse lives in his charge is doomed 
to disaster and forced to cruelty if he does not habitually look ahead. The relative enfeeblement of the tradition or the instinct to store and save may in critical times of shortage imperil national welfare, and one can but hope that in this, as in parallel cases, there will be a replacement of instinctive or traditional habit by deliberate rational purpose. As society develops it is ever shedding the unplastic and the incongruent, as a growing lobster molts its encumbering sherd. But in putting on a new garment adapted to changed times and changed folk-ways, it is ours to make sure that it be not less effective than was the old-fashioned jacket of thrift. 


\section{XXV \\ THE ROVING IMPULSE}

NE of the recent studies in human heredity which we owe to the energy of Dr. C. B. Davenport and the generosity of the supporters of the Station for Experimental Evolution at Cold Spring Harbor, Long Island, concerns those interesting variants who are called "rovers." In a marked and specific way they are restless and disinclined to settle down, they run away from home, they play truant from school, they suddenly resign good situations, they disappear for years, they are "rolling-stones" and in extreme cases fugitives and vagabonds on the earth. To a greater or less extent their life is swayed by a wandering impulse which now and again becomes irresistible. When the impulse is strong and well-marked its expression is spoken of as nomadism, and it appears to be in a high degree heritable. It may find outcrop in a quite pathological "fugue" when the wanderer is found far from home in a dazed or excited state, or in a harmless passion for travel and exploration, but it seems to be a specific bent. It finds expression in children more frequently than in adults, it is commoner among men than among women, it is commonest of all during adolescence. But the 
word "nomadism" loses in value if it is laxly applied, as some investigators have done, to commercial travelers, peddlers, missionaries, fugitives from justice, crusaders, and Sioux Indians! When Herbert Spencer was thirteen he ran away from his uncle's house and made for home, walking 48 miles on the first day, 47 miles on the second, and we do not know how many on the third. But there is not any reason to think of the young philosopher as a nomad; it is enough to know that he was home-sick, and that he was moved by a sense of having been unjustly treated.

The first question is as to the reality of a welldefined idiosyncrasy which may be called a roving bent. Is it a " unit character," like great mathematical or musical ability, or can the illustrations of it be analyzed into a number of component factors, such as curiosity, pique, dislike of humdrum work, antipathy to particular people, unwillingness to face the consequences of misdeeds, and so on? It appears to be the general opinion of alienists that there are quite specific "nomadic" sports or variations, and this is supported by Dr. Davenport's evidence of the recurrence of "nomadic" traits generation after generation in a hundred family histories. He regards nomadism as probably a sex-linked recessive character. "Sons are nomadic only when their mothers belong to nomadic stock. Daughters are nomadic only when the mother belongs to such stock and the father is actually nomadic. When both parents are nomadic 
the expectation is that all the children will be." As to the not infrequent concomitance of nomadism with periodic abnormal psychoses, such as depression or hysteria, Dr. Davenport thinks that this simply means that these abnormal states weaken or paralyze the usual inhibitions, and thus allow the nomadic impulse to assert itself. $\mathrm{He}$ is convinced that nomadism is a perfectly definite heritable character.

The second question is whether "roving" is a new variation-a germinal experiment so to speak, or an atavism in the wide sense-a reversionary outcrop of an antique and once widespread human instinct. Or it may be that there are two types. Dr. Davenport regards nomadism rather as a negative than as a positive trait, holding that the characters which normally make for steadiness and settling-down are weak or absent, with the result that a primitive wandering impulse finds uninhibited expression. As he states it, in modern phraseology, "the nomadic impulse depends upon the absence of a simple sex-linked gene that "determines' domesticity" - " gene" meaning a "unitfactor" or particular component in the germinal inheritance. On this view, we are all bearers of the vestiges at least of an ancient wandering instinct supposed to be primitive in mankind, but we normally inhibit or regularize its development or expression. This inhibition comes about organically, because less primitive characters, such as having and loving a home, are stronger than the 
waning nomadic instincts. It also comes about in the ordinary course of social discipline, which soon makes us feel that it does not do to be always running away. Dr. Davenport makes the interesting point that the choice of an occupation often illustrates an attempt to satisfy a roving impulse. Thus the antithesis between tinker and tailor is familiar, and the railway guard and the itinerant preacher may be "rovers" in disguise. If the assumption be correct that primitive man was nomadic in the ordinary sense of the word, a probability is established in favor of Dr. Davenport's view that a wandering tendency is still widespread among men as a surviving ancient trait which now and again asserts itself. If the assumption be correct, gipsies, and others like them, may be interpreted as still retaining in considerable numbers the old-fashioned roaming habit, but care must be taken to discriminate if possible between tribes or groups who wander because they will and those who wander because they must. Some may have become hunters and fishers because of a nomadic bent, but others because the environmental conditions did not admit of agriculture or stable homesteads. The way in which the East Coast herring fishermen follow for more than half the year the appearance of the fish-the undecided question as to mass-movements of herring need not be raisedaround our shores is a modern instance of roaming with an economic rather than a temperamental basis. 
It is interesting, we think, to inquire whether there may not be two kinds of nomadism. It may, be that roving manifestations confined to early childhood, or to adolescence, or associated with marked lack of control and grip, are due to the outcrop of an ancestral trait, while another form expresses an independent variation, a new departure, an organismal experiment in the direction of exploration and novelty-seeking. It is marked by great power of control and by resolute resistance, though it sways its possessors restlessly. Perhaps many of the great explorers and naturalist-travelers illustrate this type, men who cannot rest, as Nansen once said, until they have gone through, or tried to go through, every room-even the ghost-roomof the vast house which is theirs.

Dr. Davenport points to the restless habits of the gorilla and the chimpanzee. The gorilla family roams about in search of food, and will rarely stay a couple of nights in the same shelter. We read that the chimpanzee never uses its sleeping platform a second night. Now it may be that the group of animals to which the ancestors of man belonged were typical nomads, but there seems great risk of fallacy when nomadism in man is likened to wandering that has a direct relation to food-getting or to periodic environmental changes. The wandering may have been initiated by variants akin to roving boys in mankind, but the impulse has been tamed and incorporated into the general inheris tance of the species in question, and may be ex: 
hibited by types which have, so far as we can judge, very little of the roving spirit in their composition. We are far from saying that there are not temperamental rovers among animals. The common crab has been known to journey along the sea-floor for about a hundred miles, and a cod may take a jaunt of several hundreds, but our point is that wanderings like those of locusts and lemmings, badly called migrations, are reactions to lack of food. We have admitted the probability that there might not be these effective racial reactions to-day, had there not arisen long ago variants with a restless, experimental, exploring, roving disposition, who conquered difficulties by circumventing and evading them, who went on a journey, discovering the truth of solvitur ambulando; but what we maintain is that locusts and lemmings are not "rovers" now. In the same way we cannot accept the American biologist's suggestion that "nomadism in man is of the same order as that of birds," for bird-migration is a long-established, smoothlyworking, regularized alternation between the feeding and resting of the winter quarters and the breeding and nesting of the summer quarters. It probably began in individual variations or mutations in the direction of "roving," but the instinct has been established and perfected in definite relation to the actual necessities of nutrition and reproduction as affected by seasonal changes.

It is important not to think of the human "rover " as necessarily pathological, for whether he is one in. 


\section{THE ROVING IMPULSE}

whom an ancient instinct has been rehabilitated, or one who has been born with a novel mind-body pattern, there are possibilities in him of up-grade development. Repression may make a criminal of the stowaway who might have been a great explorer, a poacher of one who might have been a naturalisttraveler, or a "rolling-stone" of one who might have been a scholar-gipsy. In the course of life, especially after experiences like those of the Great War, many who were for a time restless may settle down enriched, while others who had a strong dose of the "gene determining domesticity" may usefully indulge the assertion of a new inclination to rove. What we venture to suggest is that these things-especially everything that shakes us from humdrum and what Shakespeare called "life-harming heaviness"-may be made to work together for good. 


\section{XXVI}

\section{THE PROBLEM OF PARASITISM}

NE of the perplexing shadows in the pleasant picture of animate nature is the frequency of parasitism. To some minds it appears as a blot spoiling the whole script. But without denying that there is some warrant for practical, æesthetic, and ethical recoil, we think that much of this is due to lack of perspective. Let us take a rapid survey of the facts. Thousands of living creatures, both plants and animals, live in or on others, bound up with them in a brutally direct nutritive dependence and incapable of living in any other way. Uninvited non-paying boarders they are, who make their hosts no return for the hospitality enjoyed. When we think of the "minor horrors of war," regarding which Dr. Shipley has written so admirably, of yard-long tapeworms and plump maw-worms in their inglorious life of ease, of mites and ticks innumerable, of fish-lice and flukes, of rusts and mildews and other parasitic fungi, and so on down to the microscopically minute bacilli and trypanosomes, we are appalled at the number and diversity of parasites. It is some relief to find that no backboned animals are parasitic unless it be the hags (Myxine), which sometimes burrow 
into the fishes caught on the fishermen's deep-sea lines. There are no parasites among Echinoderms and few among Mollusks and Cœlentera, perhaps in part because the life of these types depends so much on the action of living lashes (cilia or flagella) in a fresh medium. Among plants most of the parasitic forms are fungi, and there are very few among flowering plants. But there is no getting away from the fact that parasitism is a very common mode of life. One of the European oaks harbors no fewer than ninety and nine different kinds of gall-flies, and the hundredth will probably have been discovered before this series of studies is published. The valuable Lac insect of India is beset by over thirty animal and vegetable parasites. The dog is a terrain for over forty; man and pig have far more. In short, no creature with a body is without a parasite, and the number that may possess a lusty host with a wide range of appetite is legion.

The association between parasite and host is often very specific; thus the larvæ of some of the freshwater mussels become temporary parasites on particular species of fishes and on no others, and the larva of the liver-fluke does not develop in Britain except within one particular kind of freshwater snail. The relation of dependence-always nutritive, and often more-between parasite and host varies greatly in intimacy, for there are external hangers-on, like fish-lice, and intimate endoparasites, which become almost part of their 
host. There are partial parasites which spend a chapter or two of their life in freedom, and there are complete parasites which pass from host to host in a never-broken vicious circle. In proportion to the intimacy of the dependence is the degeneration of the parasite, which affects especially the sensory, nervous, muscular, and alimentary systems. The reproductive system, on the other hand, is often highly developed and the multiplication very prolific. This may be correlated primarily with the abundance of stimulating food available without exertion, and secondarily with the enormous chances of death in the life-history. For most of the parasites owe their survival to being many, not to being strong. The intricacies in the life-histories are often extraordinary, and are due in part to the fact that the parasite has to share in the knots in which their hosts are involved in the web of life, for it is natural enough that the bladderworm of the mouse should become the tapeworm of the cat. Ugly parasites are common, but many are conspicuously well adapted. Thus the tapeworm absorbs food by the whole surface of its body; it is fixed to its host by muscular adhesive suckers and often by attaching hooks as well; it can thrive with a minimum of oxygen; it has a mysterious "antibody" which saves it from being digested in its host's intestine; it produces millions of eggs which it is able to fertilize of itself. It may be repulsive, but in the technical biological sense, relative to given conditions, it is "fit." 


\section{THE PROBLEM OF PARASITISM 201}

The repugnance which many people feel when they think of parasites is partly practical. They resent the fact that a contemptible microbe kills the genius before he comes of age, and that paltry flies put a drag on the wheel of the chariot of civilization. But this is a one-sided view. Many parasites do little harm to their host; a modus vivendi has been established. The thousands of Nematodes in the food-canal of a grouse seem of no moment if the bird be healthy. If it be of a weakly constitution, however, the parasites, otherwise trivial, may gain the upper hand and eliminate their host. As this sifting makes for racial health it cannot be called abhorrent. The effects of parasites on their hosts are extraordinarily varied; some give off toxic substances; others, like the beautiful Infusorians in a horse's stomach, appear to be to some extent helpful; some cause internal lesions, and others provoke beautiful imprisoning growths like the oak-apples in the wood and the pearls in the oyster. The sturdie-worm causes locomotor ataxia in the sheep whose brain it inhabits, but fish-lice seem often entirely unimportant to their bearers. Almost every earthworm has parasitic Gregarines in its reproductive organs, but they are not usually of moment; on the other hand, the parasitic Crustaceans known as Rhizocephala actually destroy the reproductive organs of crabs. More than that, they change the constitution of the male towards the female type, so that a small ovary sometimes develops; the shape of the abdomen approximates 
to that of the female, and the protruding parasite is actually guarded by its bearer as if it were a bunch of eggs. On the other hand, many external parasites behave as if their end in life was to do for their host what he will not do for himself, namely, keep his skin clean. Great mortality from parasites is in most cases due to immigrant animals entering a fresh area and becoming liable to attack by parasites to which they can offer no natural resistance, as when cattle enter the Tse-tse fly belt and become infected with trypanosomes which are fatal to them, though doing little or no damage to the indigenous animals in which they are at home. Similarly, the fatality of a new parasite in a new population is familiar, as in the case of the Black Death in England, which was due to the introduction of the microbe of bubonic plague from the East. It is not the parasite's interest to kill its host-that is killing the goose that lays the golden eggs-but it is highly probable that very aggressive parasites have eliminated themselves from time to time by turning into beasts of prey. For it seems almost legitimate to place by themselves, and outside the ranks of ordinary parasites, the very virulent microbes like Plague Bacilli and Sleeping-Sickness Trypanosomes. They are internal plants-of-prey and beasts-of-prey, and it is interesting to notice that some of them live an exceedingly active life, which is not the usual habit of adult parasites.

Many parasites are æsthetically repulsive in form, color, and movements, and it is instructive to 
compare the attractive free stages of some of them with the ungraceful, bloated, absorbent masses of tissue which they may become as adults. The ugliness is Nature's stamp of degeneracy and dishonor; it is the natural result of retrogression, involution, sluggishness, and overfeeding. Beauty is universal among free-living, full-grown, wild creatures in a state of health and away from man's fingers; ugliness is the brand of failure. As George Meredith said: "Ugliness is only half-way to a thing." It is interesting to notice that the dodder and mistletoe, which every one recognizes as beautiful, are only partial parasites. Inextricably associated with the purely æsthetic repugnance is the feeling that an organism which does not fend for itself is a sort of contradiction in terms.

To many minds, indeed, the darkness of the shadow is in the inconsistency between the parasitic régime and Nature's usual insistence on a strenuous life. This must be admitted, and yet there are extenuating circumstances. In the struggle for existence the organism finds itself beset by environing difficulties and limitations, and one of the reactions that sometimes pay is to become a parasite. But the struggling creature does not see it in our light, and has no prevision of the facilis descensus on which it sets foot. It may try to survive inside a larger organism which has swallowed it, just as another may try to survive in a cave, and another in a warm spring. In its searching for food and shelter it may discover in or on another organism 


\section{4}

SECRETS OF ANIMAL LIFE

what is for it simply a new and very promiseful world. In many cases it is only the mother-animal that is parasitic, so that it is not necessarily a selfish evasion of struggle this parasitism. It is not easy to fence off parasites that may be of a little benefit to their hosts from symbions and commensals that are, on the whole, beneficial, but levy a slight tax. All these linkages are to be looked at broadly as expressions of a widespread tendency to weave lives together in a web-an external systematization or correlation which has been of great moment in evolution.

Some have explained that it is not the destructiveness of parasites that they object to, nor their ugliness, nor even their feckless, drifting life, but a certain element of devilry. The ichneumon-fly lays her eggs in a caterpillar; the hatched grubs feed on the living tissues; they make their way out eventually to begin a new phase of life, having killed their host. It is very difficult in such cases to avoid anthropomorphism. Perhaps it does not matter much to the caterpillar whether it is devoured from the inside or from the outside, and perhaps the ichneumon larvæ are rather beasts of prey than parasites. This, at least, is certain - that what the ichneumon insect does to the caterpillar is not so repulsive as what man often does to man, for man knows or ought to know what he is doing. The devilry, indeed, is all, unfortunately, with the man, for the icheumon's behavior is the expression not so much of devilry as of a certain "wildness" 


\section{THE PROBLEM OF PARASITISM 205}

that often crops out in Nature. No explanation can be offered except that organisms, even plants, have in them something akin to the artist's genius. They have great resources, they are creative, and they are free. 


\section{XXVII}

\section{WONDERS OF INSTINCT}

HEW men have had a better right to speak about instinct than Henri Fabre, whom Darwin in The Origin of Species spoke of as "that inimitable observer," for his genius in scrutiny as well as in sympathy brought him into unusually close acquaintance with the life of insects where instinctive behavior reaches its climax. For whatever be our theory of instinct, there is no doubt that it is seen in its purest and most perfect expression in those creatures which belong to what Sir Ray Lankester calls the "little-brain" type. When we pass from ants, bees, and wasps to the big-brained birds we feel at once a change of air; inference and learning are at work as well as the inborn inspirations of instinct. The appearance of a collection of Fabre's essays under the title The Wonders of Instinct ${ }^{1}$ has brought us again to face the old puzzle: What is the nature of instinctive behavior? But let us first ask the humbler question: In what particular ways is instinct wonderful, where all is wonderful?

The first marvel that the great naturalist's disclosures suggest is the extraordinary perfection

${ }^{1}$ Fisher Unwin. 10s. 6d. net. 
which instinctive behavior often exhibits. The solitary wasp called Eumenes amedei attains great excellence alike in the chase and in the craft of building; it is "a Nimrod and a Vitruvius by turns." With minute pebbles and salivated mortar it builds a finely-finished cupola about threequarters of an inch in height; the outside is covered with glistening grains of quartz or sometimes with tiny snail shells; the orifice at the top is "like the mouth of an amphora, gracefully curved, worthy of a potter's wheel." After the mother wasp has placed an egg in her well-fashioned nest, she adds five to ten small caterpillars, and it is remarkable that the egg in the well-stocked nest develops into a female wasp, while that in the meagerly provisioned nest becomes the much smaller male. It may be that the difference in the nutritive supply determines the forthcoming sex, giving a constitutional bias to one side or the other, for Fabre was surely off the track in supposing that "the mother knows beforehand the sex of the egg she is about to lay," and has "a clear vision of the invisible." But to return to the nest, after egglaying and victualing, the next step is to close the orifice with a cement plug, in which there is always set a single tiny pebble. "The ritual never varies." But the touch of perfection is to be found inside, not outside. It appears that the stung caterpillars that form the living larder inside the wasp's cell are but imperfectly paralyzed, and toss about when touched. Now the least pressure would crush the 
delicate egg. So it is hung by a thread from the roof of the cupola, and after the Eumenes grub hatches, it makes the cast shell of the egg into a flexible staircase so that it can reach the caterpillars and bite them, yet retreat if they are too vigorously recalcitrant. This is perfection.

The second point which Fabre's observations illustrate very finely is the frequently serial character of instinctive behavior. There is a particular sequence, and that sequence is adaptive. The Capricorn grub of the Cerambyx beetle burrows for three years on end in the depths of an oak tree. But when it is full-grown and the time of its metamorphosis draws near, it moves to the periphery and makes a passage almost out, leaving only a film-like screen, just as if it knew that the winged beetle to emerge from the pupa-case would otherwise be buried alive. It then draws back a little in its gallery and makes an outer barricade of particles of chopped wood, and inside that an inner partition like a white skull-cap or acorn-cup, composed, strange to say, of carbonate of lime and some organic cement. The next step is to make on the side of the exit-way a transformationchamber. This is three or four inches long, and is padded "with a fine swan's down, a delicate precaution taken by the rough worm on behalf of the tender pupa." The next step is to fall asleep and dream of becoming a beetle. "The grub lays asici: its tools, molts its cuticle and becomes a pupa, lying, weakness personified, on a soft couch. The 
head is always turned towards the door." This seems a minute detail, but the strength of a chain is that of its weakest link. The supple grub can turn this way or that in its chamber, but the coming Cerambyx will not be able to turn or bend. "He must absolutely find the door in front of him, lest he perish in the casket. Should the grub forget this little formality, should it lie down to its nymphal sleep with its head at the back of the cell, the Capricorn is infallibly lost; his cradle becomes a hopeless dungeon." But the grub forgets as little as it learns!

The third feature which Fabre's studies bring into prominence is the limitation of instinct. Often subtle and perfect, without a loose thread from first to last, the instinctive routine often ends in an almost ridiculous fiasco, when a grain of intelligence would have saved the situation. The fact is, of course, that the instinctive capacity has been slowly and exquisitely adapted for the ninetynine per cent. of normal circumstances, not to meet the one per cent. of exceptional contretemps. Strange it is, however, that the burying beetles will allow themselves to pine away in an artificial prison which has for such expert tunnel-makers a widelyopen door-widely open physically, but closed psychically. They often show great pertinacity in trying to bury a mouse in difficult conditions, but Fabre's ingenious experiments showed that they were baffled by simple tricks of suspension where a touch in the right direction would have made the 
booty available. The observer once made, as is well known, a closed circuit of procession-caterpillars on the rim of a palm-vase in his garden, and round this on a silken trail the creatures continued crawling in futile circumambulation for seven times twenty-four hours, working round and round three hundred and thirty-five times and covering a distance of a good bit over a quarter of a mile. This and a score of similar cases illustrate what Fabre calls "the abysmal stupidity" of insects whenever the least accident occurs. We should rather say the tyranny of instinctive impulse in artificial or quite unusual circumstances. "The caterpillars in distress, starved, shelterless, chilled with cold at night, cling obstinately to the silk ribbon covered hundreds of times, because they lack the rudimentary glimmers of reason which would advise them to abandon it." We should rather say because the hand of the past in the form of a routine of response enregistered in the nervous system was too strong to allow of any initiative in the present.

To what theory do these interesting facts point? It seems to us that Bergson was right in insisting that instinctive behavior is on a different evolutionary tack from intelligent behavior. The latter is inferential and reflective; the former is impulsive and intuitive. Intelligence implies an appreciation of relations; instinct implies an appreciation of a particular configuration of circumstances. Intelligence is as much made as born; instinctive capacity is much more inborn than made. In the 
course of ages the fountain of change in the germcells has supplied material for cumulative improvements in structure, in the creature's instruments. In the course of ages the same fountain has supplied material for cumulative improvements in the controlling organization, the nervous system, objectively regarded, the mental life subjectively regarded. The correlation of improved control and improved instruments is effected in the slow winnowing of Natural Selection, which always operates in definite reference to a particular set of often-recurrent or absolutely critical external circumstances. These, in turn, may gradually become more intricate and subtle, and thus act as an evolving sieve. We agree with those who find it difficult to think over a complicated case of instinctive routine without the hypothesis that it is suffused with some degree of awareness and sustained by some degree of endeavor. We find no warrant for regarding instinct as a sort of low-grade intelligence, still less as the result of lapsed intelligence. "We think Fabre was nearer the truth with his phrase " inborn inspiration," and that we make difficulties for ourselves by trying to give purely physiological explanations of what is, like memory, a more than physiological phenomenon. It seems to have been part of the tactics of Nature to enregister capacity in the organism so as to give it greater freedom for fresh adventure. In the case of instinctive capacity, which gives the creature a rapid mastery of intricate situations, the enregistration has sometimes outshot 
the mark, and for lack of a little logic the creature is often fatally nonplussed. But in the big-brained type, with its rapid educability and capacity for profiting by experience, there is likewise liability to failure, and very notably in mankind, for lack of more instinctive wisdom. On the whole, however, intelligence is the more excellent way, especially when external registration in a social heritage is added thereto. 


\section{XXVIII}

\section{MAKING A HOME FOR LIFE}

TJ HETHER the earth condensed from a whirling ring separated off from a spinning nebular mass, whose center formed our sun, or whether it began its separate existence as a knot in a spiral nebula heaved off from the sun, or whether its origin was otherwise, there was a time when it passed from being "without form and void" to become a dense body with a predominantly metallic core and an outer slag of lighter materials. At that time, preferably left undated, but many millions of years ago, the high temperature excluded the possibility of there being upon the earth anything like the living organisms we know. The time for life was not yet, and what we wish to think over are some of the preparations (if the word, not quite scientific, we fear, be permissible) that made the earth fit to be, if not mother of, in any case a home for, living creatures. When these eventually came to their own, many of them acquired a considerable toughness, and some a capacity for insurgence, but the present-day delicacy of individual beginnings, the tenuity of the germ, the helplessness of the infant, remind us of the probable frailty of the earliest forms of life. It is interesting to 
inquire how the callous, rough-and-tumble condilions of the outer world allowed of the germination and growth of that tender plant which we call life. In this inquiry we shall chiefly follow the considerations recently brought forward by Professor Chamberlin in his Origin of the Earth (Chicago University Press, 1916), and by Professor Henderson in his Order of Nature (Harvard University Press, I9I7).

Around the young earth, more or less cooled down, there was wrapped an atmosphere, laden with "planetesimal" dust which sank gently on to the surface and drifted about in billowy, changeful dunes. By its early "ultra-Krakatoan" atmosphere, as Professor Chamberlin calls it, "the young earth was blanketed against intensities of radiance from without" (a younger, more intensely radiant sun) "and inequalities of radiance from within." This "preparation" afforded by the atmosphere was probably of great importance, for the average living creature, as we know it, is adapted to mild temperatures and gentle reactions and ill suited for violent vicissitudes. Time passed, and from the growing atmosphere water condensed on the surface of the earth, and was gradually absorbed by the porous, dusty mantle, till by and by in the hollows among the dunes there appeared pools and lakelets, from which grew lakes and seas. To an atmosphere was added a second "preparation," a hydrosphere, and that brought the possibility of life nearer. 
For, without going very deeply into the subject, it is clear that water was a precursor of life, just as it now is an essential concomitant of all vital activity. Professor Henderson has worked out its appreciation. "Water can dissolve a larger variety of substances in greater concentration than any other liquid"; "an enormous quantity of heat is necessary in order completely to evaporate away a lake or pond, and a smaller, but still very large, quantity must be given off before such a body of water can freeze throughout its whole extent"; the well-known anomalous expansion of fresh water near the freezing-point conserves liquid water and the life in it. And what shall we say of its capacity for hydrolytic cleavage, or of the mobility of its molecules, so important in bodily functions?

But just as water necessarily appeared upon the earth when the times were ripe, so carbon dioxide was as necessarily present as a primary constituent in the air, and the relations of the two made for progress. For the law of the solubility of carbon dioxide in water is such that at temperatures consistent with the presence of a hydrosphere " it must always be somewhat evenly distributed between the air and the waters of the globe. Water can never wash the carbonic acid out of the air, nor the extract it from the water." Moreover, the presence of carbonic acid in the rain enabled the waters of the earth to mobilize in moderation the resources locked up in minerals.

The origin of living organisms upon the earth 
remains an unread riddle; but, in spite of admittedly great difficulties, many evolutionists incline to the theory that very simple living creatures may have arisen from so-called inanimate materials as the outcome of natural synthetic processes. If this be so, a new significance appears in the abundance of carbon, hydrogen, and oxygen on the surface of the juvenile earth, and in what the chemists tell us of the unique ensemble of properties possessed by these three wonderful elements. They have great reactivity; they make great diversity possible; they make for concentrations and complexifications, and these again favor the formation of colloidal systems. Now, all living creatures are essentially built up of proteins and other carbon compounds in a colloidal state. Only in that state could materials have the pliancy and the permeability which are characteristic of organisms, and that "energia" of which Thomas Graham wrote in I86I that it "may be looked upon as the probably primary source of the force appearing in the phenomena of vitality," Now, while almost all substances can be made to assume the heterogeneous colloidal state, with ultra-microscopic particles or droplets in suspension or dispersion in some medium, there is a notable readiness on the part of complex chemical substances to pass into that "dynamical state," as Graham called it. But, as Professor Henderson reminds us, "of all the chemical elements, hydrogen, carbon, and oxygen possess the greatest number of compounds and 
enter into the greatest number of reactions." "The unique properties of hydrogen, carbon, and oxygen, of water and carbon dioxide, are uniquely favorable to the existence of the greatest possible number, variety and quantity of components of systems."

Along with the special properties of carbon, hydrogen, and oxygen, we must think of their very wide distribution, which again may be associated causally, as Mendeléeff indicated, with their small atomic weights. ${ }^{1}$ Continuing our story, we see the interest of an idea which Professor Chamberlin suggests, that the pores of the growing soil might afford "an adequate mechanism for holding, protecting, and preserving the products of each successive step in such a way as to favor the next synthetic step." And whether "spontaneous generation" took place in the pores of the soil, or whether the appearance of living organisms was due to factors which remain outside the scientific universe of discourse, it is certain that the natural conditions were propitious. Thus the soil supplies a sort of circulatory mechanism for bringing in supplies and carrying away waste. There is an intricate canal system of capillary spaces and air-ducts in the soil. Nothing could be better for the young forms of life, however these arose.

Of incalculable importance has been throughout the ages the persistent circulation of matter, and the meteorological cycle in particular. Water

${ }^{1}$ Letter to Nerw Statesman, June 8, 1918, p. I9I. 
condenses from the atmosphere, percolates through the soil, with the help of the associated carbon dioxide dissolves mineral matter, flows to the sea, and rises again in cloud. Thus it regulates the temperature of land and sea, mobilizes and disperses large quantities of elements, gives the sea an approximate constancy of composition, canalizes the earth, produces great terrestrial diversity, and so on. So from Professor Henderson's panegyric on water as a factor in evolution we pass naturally to Professor Chamberlin's emphasis on the relative uniformity which the meteorological cycle and other processes have ensured. "Perhaps there is no fact in the earth's career more remarkable than the fidelity with which the very narrow ranges of temperature, and the not less narrow ranges of atmospheric constituents essential to the evolution of life, have been maintained, while oscillations within these permissible ranges have freely prevailed. These limits and these oscillations were perhaps as imperative for life's origin as for its prolonged maintenance." The steadiness of the physico-chemical environment, which has been friendly to the ascent of life, is not inconsistent with there being a gradual change in soil and in climate which may have served as a spur to the evolution of organisms. Organic evolution has had its pulse, responding to ameliorating or depressing external conditions, just as our individual pulse responds to a sunny or a gloomy day. "Does not a man," John Burroughs said, "imply a cooler 
planet and a greater depth and refinement of soil than a dinosaur?"

The old lady saw providential design in the way so many fine rivers flowed through so many large towns. Are we making the same sort of mistake in discerning that the constitution of the inanimate is in many unique ways eminently favorable to the interests of living creatures? If it be true that primitive living creatures arose by processes of natural synthesis upon the earth, and are in a deep sense bone of her bone and flesh of her flesh, it is not surprising that the mother should be friendly to her children. One would expect systems thus arising to be, as it were, at home among the conditions which gave them birth. But what strikes one is that the callous earth has been so conspicuously friendly, supplying not merely a shelter, but a stimulating and educative home. Such a multitude of "preparations" seem to conspire together to facilitate life-the making of the atmosphere and hydrosphere, the properties of water and carbonic acid gas separately and together, the properties and abundance of carbon, hydrogen, and oxygen, the ready assumption of a colloidal state by complex carbon compounds, the character of the porous soil, and the meteorological cycle. The whole aspect of life would have been different if fresh water had not the anomalous property of expanding near the freezing-point, just as the whole aspect of human history would have been different if our atmosphere had been too cloudy to allow us 
to see the stars. It is easy to assert that with other elements, with other properties, there might have been other living creatures, very different from those we know, yet just as well adapted and just as marvelous and beautiful; but no one has substantiated this assertion. The fact to stand firm on is that the order of inanimate Nature has been such that it facilitated the order and progress of animate Nature. The "material nature"-the stones and mortar of the world-must be admitted to have had a character which made the preparation of a home for life possible-a potentiality to which we do not seem to do anything like full justice unless we call it purposive. But preparing a home for life was not all, for far in the future there was the rational mind of man, prying into the facts, puzzling over them, in part understanding them; and if this also evolved naturally, there is no way, even if we wished, of escaping the conclusion that what we call material is also spiritual, for there can be nothing in the end which was not also present in kind in the beginning. It looks, then, as if Nature was Nature for a purpose. 


\section{XXIX}

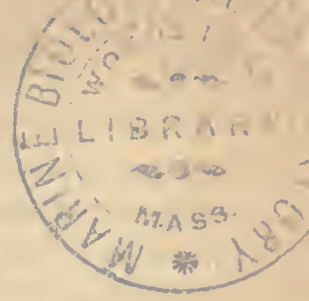

\section{WITH DARWIN FORWARDS.}

$T^{T}$ is difficult not to sympathize with the idea 1 that there must be some hereditary entailment of at least a representation of many of the individual gains made by living creatures during their lifetime. It is difficult to shut out the belief that individual experience must somehow count in racial evolution. Thus it is not surprising that we should often hear the slogan "Back to Lamarck!" The importance of the questions raised is so great that no apology is needed for an attempt to suggest. the other side of the case. We must remember Herbert Spencer's conviction, that "a right answer to the question whether acquired characters are or are not inherited underlies right beliefs, not only in Biology and Psychology, bit also in Education, Ethics, and Politics.... A grave responsibility rests on biologists in respect of the general question, since wrong answers lead, among other effects, to wrong belief about social affairs, and to disastrous social actions." These words should remove all trace of polemical argumentation from our inquiry.

The central question is this: Does a structural or functional change directly induced in the body of an individual organism as the result of some peculiarity 
in function (use and disuse), or in environment and nurture generally, ever affect the germ-plasm in the reproductive organs in such a specific or representative way that the offspring will thereby, though not subjected to the nurtural peculiarity in question, exhibit the same modification that the parent acquired, or even an approximation towards it? Modifications are dints of direct extrinsic origin, in contrast to variations or mutations which are expressions of germinal changefulness; and the precise point is whether the acquirer of the modification can entail it on his progeny as such or in any representative degree. It is admitted that deep dints may have secondary effects on the germ-cells and on the unborn offspring; but this is not the question at issue. It is also probable that long-continued, deeply-saturating peculiarities of nurture may produce substances that enter into the germ-cell or into the embryonic body (e.g. the mammal in its ante-natal life of symbiosis with its mother, or the unliberated seed of the flowering plant), but there is as yet no convincing evidence that the resulting changes grip the constitution permanently. It would perhaps facilitate our understanding of organic evolution if we found reason to believe that at least some advantageous modifications, hammered on to the individual, could be transmitted ever so little, but the difficulty is to find convincing evidence. So it has come about, not through any preference of darkness to light, but by pressure of hard facts, that the majority of naturalists now 
hold a position of skepticism as to the transmissibility of acquired characters. This skepticism was. early hinted at by Kant, His, Pritchard, and others, and afterwards expressed in a masterly way by Galton and by Weismann. For many years there continued a searching criticism of case after case of alleged transmission of acquired characters, and now there is widespread agreement with Sir Ray Lankester's pronouncement, that one of the notable advances of post-Darwinian æetiology has been getting rid of all trace of the Lamarckian theory of the transmission of individually acquired characters or somatic modifications. Of recent years, however, there have been many, and of course welcome, signs of a "Back to Lamarck" reaction, originating perhaps in Samuel Butler, and diversely expressed by Semon, Cunningham, Hartog, Francis Darwin, Bergson, Russell, Darbishire, and others. We may be permitted to refer in particular to Rignano, the genial, indefatigable, and disinterested editor of the brilliant journal Scientia-a sound organon of pacific internationalism: Now, back to Lamarck let us certainly go to try to understand his position more thoroughly, as Russell has done in his Form and Function (I916). Back to Lamarck let us certainly go in order to discover whether we cannot, without disloyalty to the known facts, re-utilize the Adriadne thread which guided the early explorer of the evolution-labyrinth. But do not let us return to Lamarck by brushing aside forty years' skeptical scrutiny of evidence, or under a 
confused impression that Darwinism denies "the racial value of good nurture," or under the influence of the cynical suggestion that the "brutal creed" of those who doubt the transmission of acquired characters has behind it the motive "to keep its money in its pocket and its power over the poor."

There are probably many like ourselves who have no radical unwillingness to return as penitents to the Lamarckian faith, if that does not mean, as it need not, any recantation of Darwinism. But we have to be converted first, and the often cited experiments made by Dr. Kammerer will not suffice. It appears to us, for instance, that Dr. Agar's experiments, which were just as careful as Kammerer's, point to the opposite conclusion. That is, at any rate, how they seem to Agar to point. Kammerer's work is very striking and very carefully conducted, but to execute a volte-face with decency we surely require more than one set of experiments by one investigator. The kind of result that Kammerer obtained may be briefly illustrated. He found that a yellow background and a damp atmosphere increased the yellowness of the common spotted salamander, and that the change was to a considerable degree transmitted. The offspring, which are hatched within their mother, start their career nearly, but not quite, as yellow as their modified parent. The experiments lasted for ten years, and it would be preposterous to criticize them in a few lines. Great praise is due to Kammerer for the painstaking care with which he met the objection 
that the light saturating through the semi-transparent tissues of the parent might directly affect the germ-cells within. We attach importance to the fact that Professor MacBride, one of our foremost zoologists, has been definitely convinced that Kammerer has proved that acquired qualities are to some extent transmitted; but in view of what has happened before, we decline to hurry back to Lamarck.

Failing, then, to be convinced that the proposition of Lamarck has been in any case proved, we return in the meantime to the Darwinian theory that the natural selection of variations has been a vera causa in evolution. But what we return to is not the theory often unjustly treated in summary statement, e.g.: "The evidently-true doctrine of the destruction of the less viable was held to explain the origin of the more viable." For Darwin made it quite clear that he postulated the raw material that was continually supplied to the sifting process, and it is only a little farther than postulating that we can go to-day when we inquire into the origin of intrinsic variations and mutations. We may point to certain variational stimuli which are known to provoke germinal change, and to the familiar opportunities which the ripening and the fertilization of the germ-cells offer for re-shufflings of the hereditary cards; but when we probe into the origin of the distinctively new it is difficult at present to get away from the postulate that the implicit organism which we call the germ-cell makes 
experiments in self-expression just as the explicit organism is ever doing. There is no need to be frightened by the word fortuitous, so often used as a reproach to Darwinism, for it is just a short way of saying, as Darwin did, that "our ignorance of the laws of variation is profound." Mr. Hookham has given us the interesting information (New Statesman, 3rd March I9I7) that Darwin approved of his vivid illustration of Nature's fortuitousness. "Whereas if man wanted to hit a mark, he aimed at it; and, if he aimed well enough, he hit it; Nature's plan was to throw up grains of sand in all the winds through all time, and eventually she hit it too, but she could not be said to aim." But we do not think that we can infer from Darwin's approbation of Mr. Hookham's image that he meant to be committed to pure chance, except that, as he explains, he could not regard the outcrop of variations as due to design or purpose. Taking a wider sweep, he wrote to another correspondent: "If we consider the whole universe, the mind refuses to look at it as the outcome of chance." His emphasis on "the principle of correlated variability, when one part varies other parts vary," also throws light on what he meant by " chance." But, in any case, we mean by Darwinism not the ipsissima verba of Charles Darwin, but the living doctrine that has legitimately developed from his central idea of the natural selection of intrinsic variations or mutations, -a doctrine which is in process of assimilating a multitude of new facts in regard to the definiteness of 
variation, the correlation of variations, the occurrence of unit characters, the brusqueness of mutations, and so on. There is a growing body of evidence, e.g., as regards chromosomes, that a variation is often a much more definite change than was formerly supposed, and the element of the casual or fortuitous seems to be reduced by the limitation that the new departure must be in some measure congruent with the germinal. organization already established. It is not a "guiding principle" we assume, but simply the unity or individuality of the organism, as real when it is telescoped down into a germ-cell as when it finds epiphany in the full-grown creature.

Tending also to a shrinkage of the apparently fortuitous is the fact, which Darwin clearly realized, that the sifting process often operates in reference to an intricate web of life, so that a nuance-a shibboleth-may have survival value; that natural selection operates, generally speaking, in relation to an external systema Natura which has been increasingly elaborated through the ages, which is indeed part of the explanation of the progressiveness of evolution. There has been an evolution of the sieves as well as of the sifted. This idea is of far-reaching importance in relation to mankind, where so much of progress is registered outside protoplasm altogether in organizations and institutions, permanent products and cities, literature and art, the whole forming a vast sifting apparatus which is itself subject in detail to critical selection 
in terms of the highest values. A's to the question whether the factors operative in ordinary organic evolution are more than complications or compositions of factors which operate in inorganic genesis, we would answer, Much more. For Natural Selection operates on what is not accounted for mechanically, and the sifting process itself is more than mechanical. For the explicit organism can often be seen to play the new cards which the implicit organism has put into its hands. Organisms are at times selected by their environment; at other times they select it. They often help to make their own sieves. All our formal statements of the tactics of organic evolution are too stiff. They tend to conceal the heart of the matter, of which, in Darwin's footsteps, we are ever getting new glimpses, that living creatures with a will to live, with an insurgent self-assertiveness, with a spirit of adventure, with an endeavor after wellbeing, do trade with time and have commerce with circumstance, as genuine agents, sharing in their own evolution. 


\section{XXX}

\section{THE MENDELIAN CLUE}

T pre-Darwinian days people spoke of Heredity with a capital letter as if it were a power or principle that did things-just as many still speak of Evolution. It was one of Darwin's many services that he showed the organic linkage between one generation and another to be anenable to scientific inquiry and statement. To him heredity was the genetic relation between successive generations-a relation that secures, through the vehicle of the germ-cells, a persistence of a large measure of specificity both in form and habit, both of microscopic architecture and chemical metabolism. His particular theory (pangenesis) of what distinguished the germ-cells from the specialized body-cells was not, indeed, acceptable, but it was with Darwin that the scientific study of heredity practically began. To his cousin, Francis Galton, and to Professor Weismann we owe the elucidation of an idea which seems to have occurred to several others - the idea of germinal continuity-that the reason for like begetting like is the persistence of a specific organization through a lineage of unspecialized germ-cells. While most of the germinal material of the fertilized ovum is used to build up the body of 
the offspring, undergoing in a most puzzling way differentiation into nerve and muscle, blood and bone, a residue is kept intact and unspecialized to form the primordium of the reproductive organs of the offspring, whence will be launched in due time another similar vessel on the adventurous voyage of life. So it comes to be that the parent is rather the trustee of the germ-plasm than the producer of the child. In a new sense the child is a chip of the old block. Or, as Bergson puts it in less static metaphor, "life is like a current passing from germ to germ through the medium of a developed organism." Though it is now clear that Weismann exaggerated the contrast and apartness of body-cells and germ-cells, the general idea of the continuity of the germ-plasm remains as one of the most important contributions to postDarwinian biology. It is the explanation of the inertia of the main mass of the inheritance, which is carried on with little change from generation to generation. For men do not gather grapes off thorns or figs off thistles. Similar material to start with; similar conditions in which to develop; therefore like begets like.

While the epoch-making experimental work of Mendel, which would have so much delighted Darwin's heart, lay buried in the records of the naturalists' society at Brünn, there was developed in Britain a statistical study of inheritance, especially associated with Sir Francis Galton and Professor Karl Pearson. It was Galton who began to study 
the inheritance of particular characters through successive generations and to measure quantitatively the degrees of hereditary resemblance. He was led to the law of ancestral inheritance, according to which the average contributions to each inherited faculty are a half from the parents, a quarter from the grandparents, an eighth from the great-grand- parents, and so on backwards in the same diminishing ratio (afterwards somewhat modified by Pearson); and another deduction was the law of filial regression or the tendency to approximate to the mean of the stock. It is necessary, however, to bear in mind that these average statistical deductions do not hold in regard to non-blending hereditary characters, and that they do not seem to take sufficient account of the fundamental distinction between inborn variations and individually acquired modifications. The latter are somatic dints due to peculiarities of nurture, and have not been proved to be transmissible; the former are expressions of germinal changefulness, and are in some cases demonstrably transmissible. Of great value, however, has been the statistical demonstration of the heritability of subtle constitutional qualities-such as fecundity and longevity-and the proof that clearly-defined mental qualities may be handed on to, and distributed among, the offspring just in the same way as bodily characters.

The first year of this century will be memorable in the annals of biology for the rediscovery of the Mendelian clue by Correns, De Vries, and Tscher- 
mak; and more progress has been made with the science of heredity since the century began than in all previous years. For this we have to thank numerous investigators-among whom Bateson stands preeminent. What are the central ideals of Mendelism? How far does it apply? What practical promise does it offer?

There are three fundamental ideas in the Mendelian conception of inheritance: I. The first is the idea of " unit characters." An inheritance is, in part at least, built up of numerous more or less clear-cut, crisply defined, non-blending characters, which are continued in some of the descendants as discrete wholes, neither merging nor dividing. If a man has his fingers all thumbs, i.e., with two joints instead of three, this unit character of "brachydactylism" is sure to be continued in a certain proportion of his descendants. Night-blindness, or the inability to see in faint light, has been traced through a lineage since near the beginning of the seventeenth century. A definite type of very intelligent dwarf has been known to reappear for four or five generations. The persistence of the Hapsburg lip is a familiar instance of the way in which a unit character comes to stay. These unit characters behave as if they were discrete entities which can be shuffled about and distributed to the offspring to some degree independently of one another. Some suppose that they are represented by specific particles in the germinal material; others would not go further than saying that they are 
represented by differences in the ultra-microscopic architecture. It is quite likely that several factors may be concerned in one character, or that one factor may influence more than one character. 2. The sccond idea in Mendelism is that of dominance. When Mendel crossed a pure-bred tall pea with a pure-bred dwarf pea, the offspring were all tall ; and he called the quality of tallness dominant to the recessive quality of dwarfness, which the hybrid offspring keep, as it were, up their sleeve. The dwarfness is not expressed, but it is certainly in the inheritance, for it reappears in a quarter of the progeny of the hybrid generation, if these are inbred or allowed to self-fertilize. If a Japanese waltzing mouse is crossed with a normal mouse, all the hybrid progeny are normal, the waltzing peculiarity being recessive to normality. If the hybrids be inbred, some of their progeny are waltzers in the average proportion of a quarter-and these waltzers might be sold as pure waltzers-although both their parents and one of their grandparents were normal. Similarly, about a third of the rest of the progeny are purely normal, while two-thirds are like the first generation of hybrids-to all appearance normal, but with the waltzing character up their sleeve. It often happens that the two parents differ, not in presenting a pair (or more) of contrasted or alternative characters, but in the one having certain unit characters which the other has not. This works out in the same way-the unit character that is present being, as it were, dominant to its own absence. In 
illustration of characters that exhibit Mendelian inheritance, the following may be cited, the dominant condition being named first in each case: Hornlessness and the presence of horns in cattle, normal hair and long "Angora " hair in rabbits and guineapigs, kinky hair and straight hair in man, crest and no crest in poultry, extra toes in poultry and the normal number four, bandless shell in wood-snail and banded shell; yellow cotyledons in peas and green ones, round seeds in peas and the wrinkled form, absence of awn in wheat and its presence, susceptibility to rust in wheat and immunity to this disease, two-rowed ears of barley and six-rowed ears, markedly dentate margin in nettle leaves and slightly toothed margin. Why one character should be dominant and another recessive is not known; a positive feature may be recessive, and a negative feature may be dominant. It should be noted that in a large number of cases of alternative or Mendelian inheritance the dominance in the offspring is not complete; thus, if black Andalusian fowls be crossed with white ones the progeny are "blue" Andalusians. 3. The third idea in Mendelism is the theory of segregation. Mendel supposed that the hybrid or cross-bred offspring produced two kinds of germ-cells in approximately equal numbers -one-half with the determiner or factor corresponding to the dominant character, and the other half without it, or with the factor corresponding to the recessive character. In other words, each germcell is "pure" with respect to any given unit 
character. If this be so, and if fertilization be fortuitous, then the Mendelian proportions must be exhibited by the offspring of the hybrid generation, namely, 25 per cent, pure recessives, 25 per cent. pure dominants, and 50 per cent. impure dominants (like the original hybrids), which, if inbred, will have offspring in the same I : 2 : I proportion as regards the particular unit character observed.

It is often asked whether there are not, as used to be believed without question, other modes of inheritance besides this Mendelian mode, and this continues to be the subject of investigation. Does the mulatto exhibit-as regards skin-color-a blend of the characters of his parents, or is the matter less simple than it seems? Are not the hybrids between long-eared and short-eared rabbits very exact intermediates between their parents, and do not hybrid cockatoos show diagrammatic blending? Or are such cases sufficiently interpreted on Mendelian lines as due to incomplete dominance, or to the fact that one character may have multiple factors which do not get cleanly segregated in the history of the germ-cells. It is one of the merits of Professor James Wilson's recent introduction to Mendelism ${ }^{1}$ in its practical aspects that it shows how results which do not seem consistent with Mendelian theory may nevertheless be brought into conformity with it. Disturbances in the Mendelian distribution may be due to factors cancelling one another, jostling one another, coupling. with one another,

'A Manual of Mendelism, 1916. A. \& C. Black. 
and so on. The doubt left in one's mind is whether the auxiliary hypotheses which make difficult cases conformable are triumphs of human ingenuity or indices of the subtlety of life. When we are led by other authorities to contemplate the disintegration or fractionization of the factors of certain unit characters, our faith is strained by what seems so like a contradiction in terms. But the scientific position is to experiment and see. Very interesting on another line are the experiments of T. H. Morgan $^{1}$ and his collaborators on the fruit-fly Drosophila, showing that "every character is the realized result of the reaction of hereditary factors with each other and with their environment." Flies of a race with a peculiar hereditary abnormality will develop normally if raised in a dry environment, but the presence within them of the factor for abnormality may be demonstrated by rearing their offspring in moisture. In other words, the expression of even Mendelian characters requires an appropriate nurture.

Professor Wilson lays stress on the fact that theoretical difficulties need not hinder the breeder from utilizing the Ariadne thread which Mendel has put into his hand. For it is becoming increasingly clear that Mendelism can enable a breeder or cultivator to reach his desired result more surely, more rapidly, and more economically. His new knowledge shows him how desirable qualities of the unit character type can be grafted on to a stock,

${ }^{1}$ The Mechanism of Mendelian Heredity. Constable, I915. 


\section{THE MENDELIAN CLUE}

and how undesirable qualities may be slipped off, and never was it more necessary than now to put all our available science into the art of cultivation and breeding. The average yield of wheat in Britain is about thirty-two bushels to the acre. Professor Wilson tells us that it might be raised to forty or even fifty. "For every day by which the life of a variety of wheat is shortened between seedtime and harvest, the wheat-growing area in Canada reaches fifty or sixty miles farther northwards." The work done in Denmark shows how the wealth of our country, so far as it proceeds from dairy cattle, might be very nearly doubled. These are two instances out of many which might be cited to illustrate the practical value of Mendelism-and it is only beginning. 


\section{XXXI}

\section{THE FOUNTAIN OF CHANGE}

NE of the fundamental problems of Biology is the origin of the distinctively new. A clever and well-proportioned dwarf is born in a family, and the interesting type may reappear in a certain proportion of his descendants for at least four generations. The unsolved problem is: What conditioned the dwarf? It is the same problem as the origin of the mathematical or the musical genius, the old problem of new departures. It is difficult to draw the line, but it seems possible to discriminate between minor novelties or "fluctuations," which differ but slightly from the parent type or may be connected with it by intermediate gradations, and the major novelties or " mutations" which represent more or less of a new pattern and are discontinuous. The contrast is not so much in the amount as in the kind of change. The copper beech, which made its appearance in the seventeenth century, may not differ very materially from an ordinary beech, but it was a discontinuous variant which arose abruptly and came to stay. Similarly, the white rat does not seem to want very much to make it a brown rat-the species whence it sprang-but it was in its day a new departure, and 
it has bred true. Our knowledge of the origin of cultivated plants is meager, but there is considerable reason to believe that they began in mutations. We know that this was the origin of the Laciniate Greater Celandine, which appeared without warning in 1590 and has been breeding true ever since. Some fluctuations seem to be transmissible, and to reappear in varying degrees in the offspring, so that the possibility of man's reaching a desired end by persistent selection remains; but the balance of present-day evidence inclines to the view that the essential step may be taken brusquely. The momentous prehistoric origin of "thrashable" wheat, for instance, may have come about abruptly and in one plant. Similarly, in regard to the origin of domesticated races of animals our knowledge is very unsatisfactory, but there are strong reasons for believing that the essential steps were due not to sifting fluctuations, but to breeding from transilient mutations. In recent years we have come to know of mutants arising in wild species and persisting. Thus the black mutant of the Peppered Moth has been very successful, and a similar variety of a certain West Indian Sugar-bird has practically supplanted the parent species. Now, whatever we may conclude as to the cause of these two novelties, we cannot at all events say that they were the results of a slow selection of individuals fluctuating in the direction of blackness. It is one of the marked changes in modern evolution-lore that increasing importance is being attached to mutations 
and less to fluctuations. (As for individually acquired modifications, imposed on the body from without, instead of emerging from the changeful germ-plasm within, they do not seem to be in themselves of much direct racial importance, for there is no cogent evidence of their transmissibility.) Darwin knew, of course, of some of the transilient or saltatory variations, which are now called mutations, but he deliberately passed them by and laid emphasis on the selection of fluctuations. His strongest reason for so doing was his conviction that the sudden "single variations" or sports would be readily swamped or leveled down by inter-crossing. It is now known, however, that one of the characteristics of mutations is their capability of complete inheritance in a varying percentage of the progeny.

To the Dutch botanist De Vries especial credit is due for his recognition of the evolutionary importance of mutations and for his study of their behavior in inheritance. It is an often-told story how he found, in I886, in a potato-garden near Hilversum, in Holland, a race of the Evening Primrose, Enothera lamarckiana, in which the mood was all mutation. In spite of Galton's insistence on the reality of transilient variations and Bateson's marshaling of instances of discontinuity, the tendency had grown'strong to dogmatize about the continuity of organic change, just as previously about the fixity of species. "Natura non facit saltus," they said; but De Vries discerned Natura saltatrix 
in the Evening Primrose of Hilversum, which, by the way, turns out to have been in the eighteenth century a wild species in North America. Three points may be emphasized. First, that some of the mutants which De Vries's sportive Enotheras threw off, as an artist might tear sketches from his notebook, were ephemeral failures, while others were viable and bred true, and could not be otherwise described than as species in the making, fingers searching, as it were, for their appropriate environmental glove. Second, in many cases the mutants were of particular interest because they showed through and through divergences-in leaf and stem and flower-certainly suggestive of some general disturbance of germinal organization. Just as if the Enothera was born again! Third, that the creativeness or sportiveness of the Evening Primrose is not restricted to De Vries's particular race of Enothera lamarckiana. It occurs in other species of Evening Primrose, and also in snapdragon and barley, in strawberry and maize, in pomace-fly and potato-beetle, in rat and man himself, and so forth. Mutations may be induced experimentally, as Professor Tower did with his potato-beetles and as Mme. Henri recently did with the bacillus of anthrax, or they may manifest themselves in wild nature, as in the already mentioned Peppered Moth and Sugar-bird. The result may be a plus or a minus, a dominant or a recessive or neither, pathological or normal. The mutation may occur after crossing or in a pure race; it may show itself 
potentially before, during, or after fertilization. In short, there is nothing hard and fast about the origin or nature of mutations: their common features are their brusque appearance, their discontinuity with the parent stock, and their capability of being transmitted intact to a certain proportion of the offspring. This brings us to notice the recent masterly work of Dr. Ruggles Gates, who has been for many years a persistent investigator of the mutations of Enothera. In his Mutation Factor in Evolution (Macmillan, I9I5) he expounds the notable advance which his researches have secured. He has been able to show in circumstantial detail that the peculiarities marking the various mutants are correlated with observable alterations in the organization of the fertilized egg-cell, especially as regards the nuclear rodlets or chromosomes of which each kind of organism has a definite number. The fundamental number of chromosomes for the genus Enothera is 14 ; this has become 15 in lata and semilata, $2 \mathrm{I}$ in semigigas, 28 in gigas, and so on. This change is observable in the fertilized egg-cell and is echoed throughout the whole plant. In this connection a reference may be permitted to what obtains in man. Competent observers have stated that the cells of the male negro have 22 chromosomes, and it is probable that the negress has, at least in some cases, 24. Now in the case of the white man and woman the enumerations of chromosomes by very careful observers point to the numbers 47 and 48 respectively. It seems to be very difficult 
to reach certainty in regard to this simple point, but there is no harm in asking, as Dr. Gates does, whether the white man may have originated from a black race by a "tetraploid mutation and its consequences." The nuclear change need not, of course, affect the number of the chromosomes; it may affect shape and size and structure. More fundamentally-but no longer visibly-a chromosome may undergo a change in its stereochemic architecture or in its functional powers. We know of remarkable mutations in bacteria, which sometimes change suddenly in their physiological properties.

The mutation theory is concerned with the origin of new characters, and Mendelism is concerned with their behavior in inheritance; so the two theories touch, and it is interesting to notice Dr. Gates' position. In the first place, it seems clear that there is no warrant for supposing that $F$ nothera lamarckiana has had a mixed ancestry and that its mutability (still unexhausted) is a result of this. Mutations may occur apart altogether from crossing, though crossing may increase their frequency or even initiate a condition of germinal instability. In the second place, the Mendelian classification of all new characters into dominants (due to the addition of a factor) and recessives (due to the loss of a factor) is much too hard and fast to cover all the facts. Germinal changes are of many and diverse kinds, and are not exhausted by addition or loss of unit factors. Some mutations illustrate Mendelian 
inheritance and some do not. Moreover, the Mendelian doctrine that all characters segregate in inheritance and are uninfluenced by crossing is far from being substantiated by Gates' results. He finds Mendelian splitting, it is true, but much more besides. He finds illustrations of blending and hints of the mutual influence of hereditary characters; he finds curious results called "mutation crosses" and "twin hybrids," which are anything but Mendelian. In short, the Mendelian categories are far too rigid, savoring too much of the inanimate domain.

The step gained is the demonstration that the bodily peculiarities of mutants are correlated with visible disturbances in the germinal organization. The next step is to discover all we can in regard to these germinal disturbances. Dr. Gates has described changes in the number, shape, size, arrangement, and structure of the chromosomes; but he is careful to point out that we must push beyond these to chemical or functional changes in particular chromosomes or parts of chromosomes. Furthermore, changes may perhaps occur in the mysterious karyolymph or gel which forms the ground-work of the nucleus. But behind the question of the nature of the germinal changes looms the problem of their origin. The Proteus of the organism has changed into the Proteus of the chromosomes. Do these germinal disturbances come about in response to subtle environmental stimuli penetrating in from without; or does the 
germ-cell-the creature, we maintain, in its onecell phase of being-play a more active part (like a Foraminifer artist building a shell of Synaptid anchors) and experiment in self-differentiation? Dr. Gates has a stern scientific mood and does not often let himself go in the region of speculation, but he does not forget that the organism is alive! "Just as an alpine climber dangling over a chasm may, by changing his hold, swing himself on to a shelf from which he can make a fresh start in some other direction, so we may think of the organism trying many unconscious experiments in its offspring, some of which are hurled by the gravitational effect of natural selection into the abyss of extinction, while others with a more fortunate turn rest on a ledge of safety whence new essays of variability begin." It is true that the author comes back to the chemical and structural complexity of the protoplasm and its unique irritability, but we wish that he had dwelt longer on his picture of the organism as a climber. It may have no fixed purpose of getting to the top, yet there may be inseparable from it a restless experimenting in self-expression, bearing in the germ-cell the same relation to the insurgent efforts of the full-grown creature that the tentatives of dreamland bear to the achievements of open-eyed endeavor. 


\section{XXXII}

\section{PROBLEM OF CAVE BLINDNESS}

DRE-EMINENT as man is, compared with other creatures, there are few of the deeper problems of Natural History which have not a practical bearing on human affairs. The touch of animate protoplasm makes the whole living world kin; and if we knew with certainty how it has come about that many cave-animals are blind or have illdeveloped eyes, we should be able to think more clearly in regard to some dwellers in darkness nearer home. Let us turn, then, sympathetically to the fact of cave blindness, and to some notable recent contributions to the evolutionary problem which it raises. Dry caves have never more than casual tenants, but damp caves harbor many creatures-from salamanders to wood-lice-which are in the strict sense at home there. The list of Troglodytes is more extensive than honorable, for leaving out of account the numerous bats and a few peculiar mice, which rest in the cave but feed by night outside of it, thus making the best of two dark worlds, we find that the bulk of the cavernicolous fauna is rather weedy. There are few cave-dwelling animals of the desperado type that we associate with Adullam; most of them are handicapped by. 
some frailty of constitution or by having fallen behind the times. Some are relices of a Glacial fauna. Their closest analogues are to be found among the shy "cryptozoic" creatures who hide under stones and bark and seldom venture forth. The true cave-dwellers are more or less adapted to the permanent conditions-darkness, constant temperature, humid atmosphere, and absence of green plants. They include (apart from bats and mice) the weird Amphibian Proteus of the great caves of Carniola and Dalmatia, three or four North American salamanders, quite a lot of small fishes, a few snails, numerous beetles and a sprinkling of other kinds of insects, many spiders (who insinuate themselves everywhere), and a few Crustaceans, besides some still smaller deer. After making sundry reservations, we recognize that those cavernicolous animals that have open-air relatives with which they may be compared tend to be dwarfish, to be monotonous or deficients in coloration, to have exquisitely developed tactility, and to have more or less rudimentary eyes. It is on this tendency towards blindness that we wish to focus attention.

There are considerable differences in the degree of degeneration which the eyes of cave animals exhibit, but there are few that have remained unaffected. In the pale Proteus, which has no pigment in its skin, the eye is without a lens and does not reach the surface of the head. This reminds us of the buried eye of the deep-water hagfish and of the way in which the very lids of the eyes of the Cape Golden 
Mole are closed. Practically complete blindness is illustrated by a North American cave-crayfish, a cave-prawn from Carniola, and some other Crustaceans. In some of the cave-beetles the degeneration has affected not only the eye but the optic ganglion as well. The cave-fishes are of special interest, for they show all grades of optic degeneration down to complete blindness. In some of them, moreover, the eyes of the young forms are less degenerate than those of the adults - a state of affairs which has been observed in some other types besides fishes. It suggests that there may be a process of individual, as distinguished from racial, degeneration.

There is no doubt as to the "naturalness" of the old theory that the "blindness" of cave-animals is the cumulative hereditary result of the disuse which living in darkness involves. Thus we cannot overlook the fact that some of the blind forms have very near relatives which live in the light of day and have well-developed eyes. To take an analogous case, that of deep and shallow water: Doflein found in Sagami Bay two varieties of a small crab, one living in the darkness of deep water and with very rudimentary eyes, the other living in shallow water and with the eyes well developed. An interesting feature of this case was that the practically blind mother-crab of the deep water was carrying about larvæ with darkly pigmented eyes, showing all the essential parts. This again points to the conclusion that the darkness may hinder the development of the eye in the individual lifetime. In other words, 
the rudimentariness may be in some cases imposed on each individual generation, and the result of peculiarities of nurture rather than of hereditary nature.

This is, of course, a matter for experiment, and some data are already available. Thus, Ogneff kept goldfishes for three years in absolute darkness, taking care to give them plenty of room and plenty of food. The result was total blindness; even the rods and cones of the retina disappeared. We may suppose, then, that if some goldfishes were washed into a cave, they might become blind. It is likely enough too (it ought to be tried) that their offspring would show even greater degeneration of the eye, being exposed to darkness from birtl. If the degeneration of the eye continued to increase after the second generation (and this also should be tested), a case would be forthcoming in support of the theory that individually acquired modifications may become in some measure part of the inheritance. But the evidence of this is not as yet forthcoming, and Ogneff's experiment should be repeated by other experimenters and on other fishes.

It is a very instructive fact that the wan Proteus from the caves, which shows no pigment in its skin, becomes rapidly spotty and then dark-colored when brought into the light. It responds like a photographic plate, and the eggs produced in the light develop into dark-colored offspring. How slow one should be to infer the absence of a potentiality 
from the fact that it finds no bodily expression in an unnatural environment!

But without excluding the possibility that the darkness and also the short commons of caves may have some effect on the development of the eye in the individual lifetime, we cannot believe that this is more than a side-issue. We must remember, for instance, that mammals begin their life in an environment of complete darkness and dwell there often for many months-in the case of the elephant for more than a year. Yet this has no prejudicial effect on the development of the eyes. Not long ago Professor Jacques Loeb made the simple experiment of rearing embryos of a minnow-like fish (a species of Fundulus) in an absolutely dark room, but no trace of blindness was observed after a month. This result is the more interesting because, as we shall see, it is very easy in the case of this fish to produce blind embryos by experimental methods. But not by darkness! There are many other difficulties in the way of the theory (which Darwin accepted) that the cave-blindness is the hereditary result of atrophy of the eye, incident on disuse and dwelling in darkness. Professor Eigenmann, who has made a special study of cavefishes, thinks that living in darkness tends at least to increase the optic degeneration, but he calls attention to the difficulty that of the four kinds of salamander living habitually in North American caves, two have quite degenerate eyes and two have them normal. But what is sauce for the goose 
should serve also for the gander. Some cave animals have normal eyes, and a few animals that live in the open, like the shore-fish Typhlogobius, are blind.

What is the other theory? Simply that the blindness arose as a germinal variation or mutation, and that it suited cave-life. For a useless organ is a weak spot. On this view there is no difficulty in the rarity of rudimentary eyes in openair conditions, for variations in an obviously disadvantageous direction tend to be eliminated. The difficulty is rather in finding facts to justify the belief that the occurrence of variations in the direction of blindness may be postulated with some show of reasonableness. It is here that the recent work of Loeb comes in. This brilliant experimenter of the Rockefeller Institute has found that it is quite easy to produce a percentage of fish-embryos (Fundulus) with defective eyes $(a)$ by unsuitable crossing, ( $b$ ) by adding a little potassium cyanide to the water, or $(c)$ by exposing the developing eggs to very low temperatures. It is not suggested that the ancestors of the blind cave-animals became blind as the result of parental mismating, or of poisoning, or of great cold; what the experiments show is that relatively slight external changes may so alter the constitution of the germ that a leap is taken in the direction of blindness. Therefore in our theory of the origin of cave-blindness it is quite legitimate to start with postulating heritable germinal mutations which we cannot definitely account for. On this view, the tendency towards 
blindness arose independently of the presence or absence of light, and Loeb finds an analogy in that hereditary kind of human blindness which is called glaucoma and is associated with atrophy of the optic nerve.

If the variations in the direction of blindness occurred long ago within the cave itself, then, if the creature was otherwise adaptable, a blind race might arise. But what if the variations occurred in the open? The first half of the answer is that they would be speedily wiped out unless they took to a cryptozoic mode of life; for blind members of an eyed race would be severely handicapped in ihe search for food and mates. The other half of the answer is that there would often be a chance that blindish variants, arising in the open, might find their way into the asylum of caves, where blindness is no disadvantage. In this connection there is great interest in Eigenmann's observation that the open-world relatives of cave-animals are constitutionally light-avoiders (i.c. negatively heliotropic) and given to keeping in contact with solid bodies (i.e. positively stereotropic). Thus, if the variation in the direction of blindness did not change the constitution, the variants would have a tendency to move into caves.

These constitutional proclivities probably count for much, but we cannot believe that they exhaust the situation, for we see all around us in the realm of organisms illustrations of a kind of behavior which spells endeavor after well-being. Even the 


\section{PROBLEM OF CAVE BLINDNESS 253}

blind variant will go on proving all things, and it will hold fast to its cave if it gets there. In its automatic elimination of the relatively unfit the environment does in a metaphorical sense select organisms, but the correlated fact is that organisms seem often quite literally to select their environment. Just as an animal with well-developed eyes will try to get out of the cave into which it has been washed, so a blind animal arising as a variant in the open may actively grope its way in. 


\section{XXXIII}

\section{CONVERGENCE IN EVOLUTION}

T $N$ the darkness of the Deep Sea there are 1 certain fishes whose eyes have dwindled to a vanishing-point. By means of delicate tactile organs they feel their way about on the sea floor. There are other abyssal fishes with enormously enlarged eyes, and it is reasonably supposed that they are able to profit by the faint illumination due to "phosphorescent" deep-sea animals. Yet a third condition is seen in a number of fishes from great depths in which the eyes are elongated into cylinders, projecting like opera-glasses on the top of the head. These have been called "telescope eyes," and they are adapted to make the most of faint light. The lens is relatively large, and the distance between it and the surface of the retina, on which the image is formed, is much greater than usual. Something of the same sort is seen in the eyes of owls, though they do not project in the same way. For the sake of simplicity let us leave the owls and two or three similar instances out of account, and focus attention on the fact that the "telescope eyes" of some deep-sea fishes are closely paralleled by "telescope eyes" in some deep-sea cuttlefishes, which, of course, are mollusks. 
This illustrates what is called convergence, the occurrence of similar adaptations to similar conditions in two sets of animals not even distantly related. Fishes and cuttlefishes are on entirely different lines of evolution; moreover, the individual development of the eye is radically different in the two cases; yet both may show telescope eyes. Weismann defined convergence as "corresponding adaptations to similar conditions in animal forms not genealogically connected with one another"; and, in addition to the unrelatedness of fish and cephalopod, he pointed out that the fishes with telescope eyes could not be regarded as the descendants of a single ancestral species which achieved the remarkable adaptation. It seems rather that, even within the class of fishes, telescope eyes have arisen independently several times over. Similarly it may be noticed that the adaptation of pectoral fins as volplanes must have occurred independently in two distinct sets of fishes, and that the transformation of muscular tissue into an electric organ must have occurred independently, at least twice, namely, in the Torpedo type and the Gymnotus type, while that of the African catfish is on a different line, being transformed glandular tissue. Very much the same as "convergence" is the term "homoplasy," which Sir Ray Lankester used for similarity of form in types of quite different pedigree. It is important for clear thinking to distinguish convergent or homoplastic resemblance from homology, which means sameness in funda- 
mental architecture and mode of development, and is always an indication of blood relationship, either near or remote. The only readily available discussion of convergence is Professor Arthur Willey's important essay Convergence in Evolution (I9I I), from which we have taken several illustrations.

Queerest of queer fishes is the sea-horse, Hippocampus, often seen in aquaria, which hangs itself from, or supports itself on, seaweeds by means of a prehensile tail, which moves dorsoventrally, not laterally, as in other fishes. It has a rapidly vibrating unpaired fin on its back, and the peculiarity of rolling its large eyes independently of one another. Now, it is curious that the far-removed chameleon, which is a quaint arboreal lizard, should show the same sort of prehensile tail as the seahorse, only more so, and the same independent rolling of the eyes. But, as Professor Willey points out, the pipe-fishes, which are related to the seahorse, but have not prehensile tails, also show independently rolling eyes. Therefore the association of separately moving eyes and prehensile tail is rather a coincidence. The significance of the mobile eyes is in relation to the sluggish habits and the relative inflexibility of the body in sea-horse and chameleon alike.

Take another example. With the exception of the American opossums and selvas, all living marsupials (pouched mammals) are natives of Australasia, where, by a geological change, their ancestors were insulated, and thus left to evolve 
by themselves apart from other mammals. Now, it seems at first sight very remarkable that the marsupials should, in the course of time, have come to present what may be called superficial duplicates of several orders of the higher mammals. The Tasmanian wolf converges towards a true wolf, the banded ant-eater to a true ant-eater, the flying phalanger to a flying squirrel, the swimming yapock to an otter, the bandicoots to rats, the marsupial mole to a true mole, and so on. The parallelism is very interesting, for marsupials are not on the same line as placental mammals; yet one is perhaps inclined to make too much of it. It must be remembered that the different kinds of habitat and the different ways of getting a livelihood that are open to mammals are not very numerous, and that Nature was therefore almost bound to repeat herself. In the same way it is not surprising that there should have been terrestrial, aquatic, and aerial reptiles in Mesozoic ages, just as there are terrestrial, aquatic, and aerial mammals to-day. Some good cases of convergence occur between rodents and insectivores, e.g., between mouse and shrew, porcupine and hedgehog, squirrel and tree-shrew; but we have given illustrations enough. The climax is to be found in the "mimicry" of unrelated types, but this problem is better kept apart, since the superficial resemblance in itself is here of survivalvalue and may be the direct result of natural selection.

In his Creative Evolution Professor Bergson dealt . 
at some length with the resemblance between the scallop's eye and the vertebrate's eye, pointing out the difficulties in interpreting this in terms of the selection of accidental variations either insensible or considerable in amount, or in terms of an interaction of internal and external forces, or in terms of use-inheritance. Without denying that each of these theories may be "true in its way," he argued that it was necessary to supplement them by the idea of a common "original impetus," which is the fundamental cause of heritable variations. But Professor Bergson unfortunately exaggerated the resemblance between the eye of the backboned animal and the "eye" of the scallop; except the "inversion of the retina" they have little in common. Moreover, the scallop's numerous eyes may not be eyes at all, in the strict sense. We do not think that Professor Bergson did justice to the subtlety of even the orthodox Darwinian position, or to the facts which have saved the neo-Darwinian, at least, from being shut up to a belief in " accidental" variations, or the rôle that the organism plays as a genuine agent in testing its germinal variations in reference to environing conditions which it has a share in selecting. But we think he was right in thinking that the interpretation of convergence is not altogether plain sailing.

If one plays long enough with cards one will repeat identical hands, and if a certain type of structure is the only one adapted to certain circumstances, or is far and away fitter than any other 
type of structure, we can theoretically suppose that it will be reached in the course of time by the selection of variations, along two or more distinct routes. In some cases, however, it is an assumption to say that the type of structure attained is the only possible solution of the problem, or by far the best and easiest. Moreover, the difficulty of Darwinian interpretation increases a little when the mode of individual development is quite different in the two cases, and when the similarities include minute details. The striking superficial resemblance between burrowing amphibian, burrowing lizard, and burrowing snake-a familiar puzzle to students of elementary zoology-is readily intelligible, for the worm-like shape is the only one possible; but is there not more difficulty in accounting for the telescope eyes of unrelated fishes and cuttlefishes, where the general idea is the same, though there are marked differences in deail and in development?

Some thoughtful students of evolution ${ }^{1}$ see no special riddle in the attainment of closely similar adaptations by unrelated types. But as we do not regard with much satisfaction or confidence the available biological interpretations of the way in which creatures of very diverse flesh and blood have often worked out the same solution to a problem, we would make three suggestions. (I) There are probably architectural laws of growth and differentiation of which we have not more than

${ }^{1}$ See for a clear-headed discussion a letter by Mr. George Hookham in The Nerw Statesman, 6th Jan., 1917, p. 325. 
glimpses. Thus the very frequent recurrence of a logarithmic spiral-in shell and horn, in intestine and cochlea-probably expresses a deep-seated growth-necessity. (2) Many an organ that looks at first sight complicated, say the pancreas or sweetbread, consists of the endless repetition of the same little structure-unit, consisting of groups of cells and the like. Some of these structure-units are very definite and have probably formed part of the common inheritance of more than one great series of animals, now attaining prominent expression and again sinking into insignificance, but never lost from the racial currency. Thus it may well be that the structural units of the sensory lateral line of most fishes are really the same as the lateral senseorgans of certain marine worms known as Capitellids. "In both cases," Frofessor Willey writes, "the essential organs consist of small, solid, roundish, epidermal buds, from which stiff sense-hairs project freely into the surrounding medium; and the resemblance is further enhanced by their segmental arrangement. The correspondence could hardly be greater, the convergence could hardly be closer, the homology could not be more remote than infinity." It may be, however, that we have here to do not with Nature repeating herself, but with the conservative persistence of a well-defined structure-unit, or " morphon," as it has been called. (3) Every art is limited by its medium, and so is organic evolution. We must not think of an animal having carte blanche in its morphogenic speculations. 
It is limited in its acquisitions by what has been already established, just as an architect in making an addition to a house is limited by the existing style. Flying birds differ greatly in detail, but within a relatively narrow range. No mutation can be considered, so to speak, which risks a loss of the secret of flight. Along this line of thought we may get another gleam of light on convergence. Other solutions than that adopted are possible to a theoretical organism, but not to this or that particular organism which has to. run in the trammels of a hereditary. organization. Why should all the ordinary mammals of our acquaintance be restricted to four legs? The dachshund often looks as if it could do with another pair about half-way along, and so does a sow-also a somewhat artificial creature. The proposition of an extra pair cannot be considered, however, for higher vertebrates are hereditarily tied down to a maximum of two pairs of limb-buds, just as they probably are to a maximum of twelve cranial nerves, where an increase would be more readily effected. It is interesting, however, to force the question back and ask why some of the lower vertebrates, notably fishes, might not have tried the experiment of an additional pair of limbs. In all probability the answer is simple: that paired limbs were established at the level of fishes, and that their primary function was in connection with balancing, not with locomotion, the locomotor organ in almost all fishes being the so-called tail. Now, for balancing purposes the choice is between 
one pair and two pairs. The evolution of a third pair of balancers would mean an increase in the functional problem of correlation without any corresponding advantage in the way of efficiency. John Burroughs writes somewhere about the gain it would be if we could open one pair of eyes after another and thus see more of the wonder of Nature. The probability is that we should see less, for the difficulty of correlating impressions would be insurmountable. It is significant that those backboneless animals that have many eyes have little vision, and that the unpaired, median, upward-looking, pineal eye which some backboned animals possessed has not been retained as an eye in higher types. It may be, then, that limits imposed by growth-necessities, by the persistence of well-defined structureunits, and by pre-existing organization may throw some additional light on the fact of convergence. 


\section{XXXIV.}

\section{DOES ACQUIRED VIGOR COUNT?}

T $N$ ordinary talk we often hear of a mysterious 1 quality called vigor, but it is very rarely that any one even asks for a definition. It is evidently something more than strength, for men with powerful thews and sinews are often far from vigorous; it is something more than health, for a centenarian sea-anemone cannot be called vigorous. The quality seems to mean capacity for living intensely, yet without any loss of balance, a power of expending energy lavishly, yet without ceasing to have plenty in reserve, an ability to resist strain and to defy fatigue. It implies being ever ready for great exertions, and yet having staying power. It must depend in part on an harmonious adjustment of the various functions of the body, including those of internal secretion and those which keep the wheels, so to speak, of the body-mind or mindbody from becoming either clogged or rusty. Probably it expresses a certain perfection in the characteristic quality which living creatures-in contrast to inanimate systems-have of circumventing the second law of thermo-dynamics-of at least delaying the tendency that energy has in its transformations to pass into unavailable form. We 
have dwelt on this popular concept of vigor not because we are confident we know what vigor precisely is, but because we are convinced that it means more than is indicated in a recent work of considerable interest which bears the title Vigor and Heredity. ${ }^{1}$ According to the author, Mr. J. Lewis Bonhote, well known as an experienced ornithologist, vigor may be defined as "activity of nutrition and function," or as "rate of metabolism." It is not so much like heat as like temperature; and it requires to be qualified by some adjective, as " high vigor," or "low vigor." It is the rate of metabolism. Now "metabolism" is just a convenient general term for the manifold complex chemical processes which go on in a living body, some of them of a constructive, synthetic, upbuilding, or assimilative character (anabolic), and others of a disruptive, analytic, down-breaking or disassimilative character (katabolic). But it is a very wide term and includes such a variety of processes that "the rate of metabolism" does not mean very much. Two creatures may have the same number of chemical transactions per hour, and yet have very little in common from a physiological point of view, just as two shops may have the same number of sales in a day and yet have very little in common commercially. And, again, if we measure the amount of metabolism that goes on in a day in various types by the amount of oxygen used up, or

${ }^{1}$ Vigor and Heredity. By J. Lewis Bonhote. West, Newman \& Co, 1915. 
by the amount of carbon dioxide given off, or by the heat evolved, the mere fact that there is equality in the amount of metabolism per day or per hour in a number of creatures does not seem to tell us much. We wish to know the nature of the metabolism in each case, for it is not a matter of indifference whether the metabolism is mainly concerned with proteids or with carbohydrates. Once again, a given animal, such as a midge, might have intense metabolism for one glorious hour of crowded life and a sluggish metabolism for twenty-three hours, and yet have its total metabolism for the day equal to that of another creature, such as an amœba, which had a constant slow-going metabolism all the time. It is open to Mr. Bonhote or any one else to call "the rate of metabolism" by the name "vigor," but we do not think it means very much unless the nature of the metabolism be defined. It is not "the pace" merely that matters, but the direction of the steps. How much of the metabolism is anabolic and how much is katabolic; how much is adding to the working capital of living matter and how much is an accumulation of reserve stock that cannot be realized except under particular conditions? These and many similar questions must be faced before we can consent to call the rate of metabolism vigor.

The author of Vigor and Heredity has been observing animals all his life and making breeding experiments, with rats and mice, cats and dogs, pigeons and poultry for fifteen years, and he has 
got something quite definite to say-something well deserving to be thought over-that the physiological condition of the parents at the time of reproduction influences the next generation. What is meant is not that two hard-set, thick-skinned, toughminded, and well-controlled parents are likely to have children after their own image, or that two slack, thin-skinned, flabby-minded, and feckless parents are likely to have children after their kind; for this would simply be the generally accepted doctrine that innate constitutional characters are entailed from generation to generation. Like tends to beget like; no grapes from thorns nor figs from thistles. But what Mr. Bonhote means is something different and something debatable.

His argument is this. Changes or peculiarities in environmental conditions (including food, warmth, humidity, and so on) have an influence on the physiological state of susceptible organisms. Corresponding to the "nurtural " changes or peculiarities there are often internal changes in the metabolism. This is admitted by all biologists. But may it not be that the character of the metabolism, environmentally modified about the time of parentage, reacts on the germ-cells and affects them in some way, so that their development, i.e. their expression of the inheritance, is different from what it would have been if the parental constitution had not been affected by the nurtural modifications? In the author's terminology, which we cannot accept, the altered vigor of the parents may affect the initial 


\section{DOES ACQUIRED VIGOR COUNT? 267}

vigor of the germ-cells, and the developmental vigor of particular items in the inheritance. The evidence brought forward in support of this view is confessedly indirect. In his experience as a breeder Mr. Bonhote has been puzzled by many of his results. He could not interpret them in terms of Mendelian, Galtonian, or any other formulæ, but he found them intelligible on the theory that the physiological condition of the parents at the time of reproduction may influence the germ-cells and their development. Low vigor in the parents will tend to be echoed in weakly offspring; high vigor will make for racial stability. But what is required is careful and skeptical criticism of all the evidence that points to the conclusion that the constitutional vigor, or vitality, or healthfulness of the parents at the time of parentage really counts in the development of the offspring. This is a momentous question, not to be answered by opinions, or on hearsay evidence, or even by reference to particular observations, such as the often-noticed delicacy of the children of a more or less invalided and wornout father. In the case of Mammals the problem is complicated by the usually prolonged period of intimate symbiosis between the mother and the offspring, during which it would be strange indeed if the development were not sometimes perturbed when there are profound changes in the maternal metabolism. That such perturbations are not more noticeable is largely due to subtle adaptations which screen the young life from harm. 
Mr. Bonhote is not much concerned with the question of the possible transmission of individually acquired bodily modifications due to peculiarities of, or changes in, function and environment; his central idea is that the physiological state of the parent, when functioning as a parent, may influence the offspring. There is abundant experimental evidence to show that a slight change in the chemical and physical medium of the germ-cells and the early embryonic stages may have a profound effect on the development. To a degree previously unsuspected, appropriate liberating stimuli are required to release the primordia of the various organs and qualities. And there are inhibitors as well as liberators. Add a drop from one philter and the embryo will be blind, from another and it will have no food-canal. It must be remembered, too, that much depends on the tempo of development, and that great changes may be brought about by accelerating here and slowing there. In this connection our author might have found, had he known, some vindication of the emphasis which he puts on "the rate of metabolism."

To make Mr. Bonhote's point quite clear, we must emphasize the fact that he is not merely concerned with the conclusion that nurture counts for much in the development or expression of the individual's hereditary nature; his suggestion is that nurture goes farther back. There is no doubt that appropriate food and warmth and moisture and the like may conspire to heighten the vigor of the parent 


\section{DOES ACQUIRED VIGOR COUNT? 269}

organisms; the hypothesis is that this is reflected in increased initial vigor in the offspring. Filled with enthusiasm for this theory-unproved though it be-Mr. Bonhote looks forward to far-reaching effects on mankind when the importance of nurture is realized. "When it is once realized that characters may be largely eliminated by environment, if brought to bear early enough, we have open to our vision possibilities far greater than any offered by the actual work of Mendel." This much of quotation will seem to many so profane that we dare not continue it. From our point of view it is not in any way profitable to pit against one another the correlated concepts of "nature" and "nurture." We believe that any nurture which contributes to the development of vigor in the sense indicated in the beginning of this article must be progressive, and that it cannot begin too soon, since it is an individual reward in itself, apart from any offchance of influencing offspring.

We know experimentally that germ-cells in the body of the parent organism may be in a general way deteriorated by various influences, such as those of radium or alcohol. But we know also that it is scientifically dangerous to argue from Rotifer to Man, even from Guinea-pig to Man. What is certain, however, is that the vigor of the mother during the time of ante-natal symbiosis with her child is of far-reaching importance. 


\section{XXXV}

\section{THE UNSEEN GOAL}

THAT one swiftly moving battleship should sink another from a distance of many miles-the victim being to ordinary eyes invisible - seems a wonderful achievement, and not less is the triumph of hitting a mark outside the range of direct observation. We know nothing of the problems of this fell gunnery; we are concerned with what seems even more difficult to understand - the way in which animals often work persistently and elaborately towards an unseen goal.

To take a typical illustration: many of the digger-wasps make burrows in the ground, in which they lay their eggs and also collect a store of paralyzed insects-a living larder for the future grubs. But it is only in a few species that the hard-working mothers survive to see their offspring. So the puzzle arises: How can the elaborate instinctive behavior have been evolved? We see a concatenation of intricate dexterities resolutely persisted in: the stinging of the victim so that it is paralyzed, yet not a corpse that would decay; the transport of the booty to the burrow-a task often requiring prodigious exertions; the placing of egg and provender in proper juxtaposition; the exclu- 
sion of possible intruders; and so on. It is no simple performance but a whole bag of tricks. The sequence is quite intelligible to us who see the end; but has the succession of events-often requiring toil and trouble-any significance to the performers? If it has no significance, how then did it evolve and why is it persisted in? If it has significance, how is that gained if the performers do not see the result of their labors?

Some of those who have thought over this problem have pointed to men who spend themselves in working towards achievements which cannot be realized in their day and generation. But the analogy does not help us, for the cathedral of Burgos, or the great afforestation, or the Chinese Encyclopredia is completed as an ideal in the minds of the human workers and is built up of elements previously actualized in experience. But the diggerwasps have had no experience bearing upon offspring. It is said that beavers sometimes dig a short-cut canal right through a large island amidstream, thus lessening the distance for transporting "logs," and such a task must engage the energies of the workers for a long time before there is any reward. For the canal does not justify itself until it is open at both ends. But such a case is not enigmatical like that of our insects, since making the island-canal is but an interesting extension of the kind of labor that finds immediate justification in the everyday life of the beaver.

Part of the answer to the riddle is to be found 
in considering the maternal care of some of the worker-ants and worker-bees, who are normally non-productive females. They mother the young as if these were their own, and we explain this by the natural supposition that this capacity dates back to the time when all the females were normally mothers, before the communal life with its marked divisin $\eta$ of labor was established. It may be remembered that fertile workers occasionally occur, and that a worker grub can be nurtured into a queen. We cannot suppose that the workers simply inherit their nursing capacities from their mother -the queen-for she does not exhibit the qualities required, being specialized for sheer maternity. We must go much farther back. Another illustration of our argument may be found in a widely different sphere-in the case of the European cuckoo. In a somewhat elaborate way the mother-bird secures the success of offspring to which she is herself a stranger. Laying her egg on the ground, she takes it in her mouth, flies with it down the hedgerow, and puts it into the selected nest of a foster-parent, and thus hits an unseen mark. The existence of other kinds of cuckoo which show less perfect evasion of parental duties convinces us that the utilization of other nests and of foster-parents was gradually evolved from a state of affairs in which cuckoos reared their own young. The egg has significance to the mother-cuckoo, who has no experience of nestling or chick, because she belongs to a race in which brooding was once the rule. 
Similarly, the digger-wasp that shows elaborate parental care, securing the safety and success of young which are never seen, does so because it belongs to a race in which rearing the young and perhaps enjoying their company was long ago the rule. The internal voice that the creature obeys is the reverberation of a distant past.

When we try to picture the establishment of an instinctive routine we naturally think of the creature wrinkling its brows from step to step, and from generation to generation deliberately introducing little improvements, until the behavior becomes at length, like a patent, extraordinarily perfect. We naturally picture the process in this way, for it is thus that we improve on our manipulations. Now without denying that animals of the smallbrained instinctive type may better their behavior by individual improvements, more or less intelligent, we cannot believe that it was in this way that instinctive behavior became established. IVho, indeed, shall dogmatize as to the impossibility of individual experiences affecting the entailed inheritance of the race, or set limits to the "mysterious wireless telegraphy of ante-natal life" ; but it does not seem likely that instinctive behavior is in any direct way due to the transmission of the results of the experiments made by the individual. Often, for instance, a very effective piece of behavior is performed only once in a lifetime, which does not give much opportunity for heritable imprinting. Often, again, the behavior is connected with the 


\section{SECRETS OF ANIMAL LIFE}

origin of new lives and is not justified to the creature until the offspring appear, so that it is only in animals that have more than one set of offspring that the organic testimony of the success of the experiment could be transmitted. Many insects and the like are annuals and die after parentage. Without shutting the door on what are called " mnemic" theories, we are forced by the difficulties they involve to the other main theory of the racial establishment of instinctive routine. On this view the steps that count are made in the dark studio of the germ-plasm. The germ-cell, an organism not in miniature so much as in microcosm, is the real inventor, the creative genius. We think too much, perhaps, of the explicit individual, too little of the implicit individuality-the germ-cell. Not to be thought of, we must remember, as like a white blood corpuscle, but rather like a Proteus animalcule that has been living on for millions of years, experimenting all the time and garnering the capacity of repeating what was successful. It has withal the power of including with its own experiments in selfexpression those of another germ-cell at the beginning of each new life. The germ-cells are the blind-artists of the realm of organisms, ever fashioning some new germinal intricacy which finds expression in some novelty of structure or habit. And on this view the individual, in which the germcell's many inventions are expressed, embodied, and exercised, may be thought of as the seeing artist, beholding the work of the germ-cell and either 
pronouncing it, in the light of the success it brings, to be good, or cursing it effectively by sinking with it into extinction. For there are variations that kill, being pathological-the germinal artist is not always quite sane-as well as variations that enrich and make for progress.

Four saving-clauses may be permitted. We must not think of the microcosmic individuality of the germ-cell in any wooden or one-sided way. We cannot conceive how it has unified in its pin's-head scope the long results of time, the treasures of the ages; but so it is. We do not understand how it is not merely protoplasm, but a daimon as well; but so it is. Secondly, we must not exaggerate the difficulty of understanding how the microcosmic individuality can make experiments-materially regarded, permutations and combinations of molecules-which have relevancy in relation to the outer world in which the macrocosmic individual will live and work. It is metaphorically like this, that within the germ-cell there is an achitecture-ideally regarded, an idea-which represents the hereditary organization and has stood the test of time. Now, the changes that can be profitably made in this architecture must be more or less congruent with the already established style, just as an experiment in our thinking, if it is to be successful and to survive, must be consonant with already established truth. Therefore the germ-cell's initiatives, though sometimes fools' experiments, partake but little of the fortuitous. 
In stating a case for the blind marksman, whose bow is bent in a direction to some degree determined by the past, and therefore with a result that has an illusory suggestion of foresight, we do not for a moment under-appreciate the rolle of the seeing artist, the explicit individual, with all its wits about it, an instinctive or intelligent or rational agent with no end of experimental power on a higher than germinal level. But our thesis is to suggest that especially in the lower reaches of life it is the blind marksman who oftenest scores. The last point is this, that, while we are probably wrong in trying to justify the ways of the species to the individual, it seems unlikely that an elaborate piece of instinctive routine could retain its impervious inertia through the ages unless a sop were offered to the individual's interests and satisfactions. So, as Goethe said, Nature gives a couple of draughts from the tankard of love as recompense for the pains of a lifetime, and in the case of animals that do not survive to see the offspring towards whose welfare they spend themselves, the parental instincts may have become in some special way linked on to the conjugal. In the latter the life of the creature is stirred to its greatest depth and rises to its greatest height. Perhaps the maternal sacrifice and the strivings of the parents towards an unseen goal may have a spice of individual significance in the reverberations of conjugal experiences, and perhaps even in ancestral reminiscences which these have reawakened. Moreover, since repression may in- 


\section{THE UNSEEN GOAL}

tensify as well as expression, it seems quite legitimate to suggest that worker-ants and worker-bees, for instance, may find some compensation for their spinsterdom in their generous vicarious motherhood. And apart from all guesses, the interesting fact has now been established for some wasps (as we have already noticed), and for some ants (as Professor Wheeler has recently proved), that nurses and mothers alike may receive from the larvæ which they feed and tend drops of an elixir that seems to serve as an extraordinarily stimulating encouragement or reward on the path of virtue. 


\section{XXXVI}

\section{BEFORE THE DAWN OF ART}

TN a recent paper in the Plilosophical Transactions of the Royal Society of London (I9I5), $\bar{M}$. Edward Heron-Allen describes the nature of the shells in some of the Foraminifera or chalkforming animals, and propounds the theory that we cannot ascribe to these unicellular creatures anything short of "intelligence." We need not quarrel over words: the important fact which this expert observer has brought to light is that these relatively simple animals sometimes exhibit consistent selection in taking to themselves the materials used in shell-formation, and that they sometimes use this material in a singularly effective manner. Most of the Foraminifera make shells of lime, which are secreted in the surface layer of the living matter, and are often of thrilling beauty. Many of them, as every one knows, have entered very considerab!y into the formation of chalk cliffs-deposits on the floor of bygone seas; many of them are accumulating to-day as Foraminiferal ooze in some of the great oceanic abysses. The calcareous shells are often exquisite, and one can spend days of joy lingering over the beauty feast which they spread before us. Wheels and spirals, globes and cones, 
fans and trumpets, towers and cupolas-what a wealth of form there is among these atomies with their hundreds of different species! One of the many interesting features is that certain of the shapes point forward to the shells of Cephalopod and Gasteropod mollusks.

The lime shells of Foraminifera have been familiar for many generations, and no one has pretended to understand them. They are secreted-simply secreted!-by organless individuals, each " a drop of protoplasm" which streams out into the water in a changeful network of delicate threads. Some salt of lime is absorbed from the sea water; it passes through the plasmic laboratory; it is laid down as an arabesque of translucent marble. That is all! We cannot explain how Globigerina makes its beautiful shell any more than we can explain how the nightingale makes his song or the poet his epic. Indeed, we are intellectually farthest from any understanding of the Globigerina's poem.

But what prompted us in this discussion had to do not with calcareous shells, but with those that are built up of extrinsic particles selected from the surroundings. It is of the so-called arenaceous Foraminifera that Mr. Heron-Allen has such wonderful things to tell us, and it is obvious at once that the problem is here more accessible-that is to say, more readily attacked-by way of experiment, such as Mr. Heron-Allen has, we believe, the patience and ingenuity to devise. In the case of calcareous shells the material that is taken in is invisible; its 
transformation (if any) is invisible; all that we do observe is the rising of a visible and tangible edifice in the transparent medium of the Foraminifer's protoplasm. But the arenaceous forms use visible ready-made building materials, and make of them an encasement. This is sometimes beautiful, oftener perhaps simply quaint; the interest centers in the selection of the materials and in the effective architecture. First as to selection: a particular kind of Foraminifer surrounded by an embarrassing wealth of alternatives will have none of them save intact sponge-spicules, out of which a transparent test is built up. Another kind will use only grains of quartz, and a third flakes of mica. What experiment will show is whether this particulate utilization of certain materials is obligatory or facultative? Is past experience so enregistered within the cell that the searching living threads will respond to sponge-spicule only? Or would the creature take Echinoderm fragments in default of anything else? Quite extraordinary is the case of a species of Technitella which makes its test of Echinoderm plates, and, having no definite oral aperture, sends its living threads flowing through the pores which these plates possess. How interesting, too, is the morsel of fact that one type that makes a shell of sponge-spicules will only use them intact, while another type will only use them broken! It has been suggested that when the materials used by a particular type are all of the same kind, and therefore of the same specific 
gravity, they will lie at the same level in the ooze; and so it may be in some cases. But that this is not all is proved by individuals which make the bulk of the shell of microscopic quartz grains, but interpolate at intervals little gems of garnet, magnetite, and perhaps topaz.

Speaking of a Foraminifer common on the rocks of the Mixon Beacon, a couple of miles out to sea from the point of Selsey Bill, Mr. Heron-Allen writes: "Among the shells of this species, the majority of which are neatly constructed in the ordinary way, of very small quartz grains, built together with a brilliantly white or deeply ferruginous cement (which gives a very distinctive coloring to the shells), frequent specimens are found which have selected and built into their shells relatively large fragments of these gem materials, and though even I would shrink from suggesting the inclusion among the higher qualities of Foraminiferal protoplasm of an ' æesthetic sense,' the selection of these grains of markedly higher specific gravity by a very restricted proportion of the animals of this species seems to me to be exceedingly significant. It affords a parallel to the instances of selection, by different species living on the same bottom, and surrounded by the same materials, of entirely. different elements, to which Lister has called attention." In contrast to a shell of quartz grains we may mention that of a species of Reophax-a fragile manychambered tube built of infinitesimally small flakes of mica, joined at their extreme margins by chitinous 
material. When the animal is living this delicate covering is pliable like chain armor.

What Mr. Heron-Allen is bold enough to call "intelligence" is even more strikingly exhibited by the effective manner in which some of the shellbuilders use their materials. Many years ago Canon Norman described how Technitella (i.e. "the little workman") builds its shell of fragments of minute sponge needles, "laid down in regular order side by side, and cemented with a mortar composed probably of the finest dust of quartz, so that the whole test is of exquisite snowy whiteness." But the accidental breakage of the shell of a species of Technitella revealed to Mr. Heron-Allen and his skilful collaborator, Mr. Earland, an even more striking fact. The whole shell-wall consists of two distinct layers of spicules, an outer layer with their long axis parallel to that of the test, and an inner layer at right angles to those outside, "giving as close an approximation to the woof and warp of a textile fabric as is possible with a rigid non-flexible material such as sponge-spicules." When we remember that this is no matter of "organic crystallization," but the result of placing extraneous materials, selectively gathered, in a definite and singularly effective arrangement, we feel that we are approaching the dawn of art. It is obvious that by the crossing of the two layers of spicules "the strength and resistance of the test to strain is enormously increased." In some cases the use of the spicules is probably protective against the attacks of minute 
burrowing worms, for long sponge-spicules radiate out in all directions, forming an effective chevaux de frise either at the mouth of the shell or all over the body of the builder.

Another extraordinary instance of unconscious skill is to be found in the shell of a species of Psammosphæra dredged by Mr. Earland on the Goldseeker in the North Sea in happier days than these (I9I5). This creature, which lives on very muddy parts of the sea-floor, uses long sponge-spicules (2-3 $\mathrm{mm}$. in length) to form the foundation-poles of an open framework or chamber. "The open spaces in the wall are then filled in with fragments of spicules carefully selected for length so as exactly to fill the spaces that are to form the walls of the test, an awkward triangular terminal space being frequently filled in with a truncated triaxial spicule." The creature lives in its roughly spherical house, and the projecting ends of the long spicules serve as "catamaran spars" to support the whole on the surface layer of the ooze. And the wonder of adaptation does not end here, for we read that a second and often a third individual will in the building of its house make use of the extreme ends of long spicules which project from its neighbor's construction. Two or three individuals united in this way by their "catamaran spars" remain entirely distinct organisms, "their only connection with one another being a purely utilitarian one, the association offering greater resistance to the mud than a single individual can attain." It is, as Mr. Heron-Allen 
says, like the beginning of a "social instinct." We make no apology for quoting these details, for the discoveries are of high importance, increasing our appreciation of the subtlety of living organisms even in their relatively simple unicellular expression. As we have noted, recourse must be had to toughminded and skeptical experiment (and happily it is not difficult to keep Foraminifera alive in artificial conditions), but it seems at present that we must attribute to creatures at the level of the Protozoa some of that skilfulness in the use of materials which we are familiar with at higher reaches of the animal kingdom-among the tube-building worms, the tailor-crabs, the hive-bees, the trap-door and web-spinning spiders, and so on up to the nestbuilding birds. Just as we have rational skill and intelligent skill and instinctive skill, so perhaps we have in these Foraminifera organic skill, when the simple individuality, pulling itself together, acts as a unity and then perhaps feels itself as one. For it is not fantastic to suppose that in such critical moments of endeavor and adventure consciousness first found, and still finds, its simplest glimmering expression. Perhaps we are nearer the truth in supposing that Technitella says to itself in a quiet way of its own, "Anch'io sono pittore," than in supposing that its artifice is describable in terms of surface-tension. Those interested in these deep problems will watch with interest the progress of Mr. Heron-Allen's and Mr. Earland's investigations in continuance of those of which we have here 
given some indication. It is difficult indeed to break off. How extraordinarily quaint, for instance, it is to read of the probability at least that Saccammina now and then breaks down its barns to build greater, "re-dissolving the cement with which its house is built, with a view to increasing its size by the interstitial addition from within of stored material"! How we are made to think by the story of Marsipella spiralis, which arrangtes its borrowed sponge-spicules in a left-handed spiral and embeds them firmly in cement, thus improving on the shell of its neighbor-species Marsipella cylindrica, which forms a long and exceedingly friable tube! "It would appear that a long series of generations of Marsipella cylindrica having suffered from this extreme friability, it was left for Marsipella spiralis to make the same great discovery as did the prehistoric genius who invented stringit has clearly realized that a twisted yarn is stronger than an untwisted wisp of fiber." This description is indeed rather more anthropomorphic in phraseology than we care for, but we venture to think that it errs on the right side. Claparède and Lachmann, writing in 1858 (when the Origin of Species was published), spoke of the "absurdity" of supposing that the complicated shell of a Foraminifer could be secreted by "an amorphous and scarcely organized mass of jelly." "The animal cannot be just a mass of sarcode." Something is now known in regard to the intricacy of protoplasmic organization, but we, speaking for ourselves, would still say: "The 
animal cannot be just a mass of sarcode." It is that, no doubt, but there is another side to the little fraction of reality which we call Technitella. It is a psycho-physical individuality whose experiments in self-expression include a masterly treatment of sponge-spicules, and illustrate that organic skill which came before the dawn of art. 


\section{XXXVII}

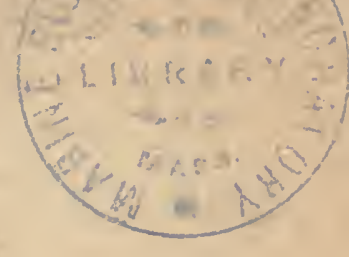

\section{MAN'S ARBOREAL APPRENTICESHIP}

M

ANY distinguished anatomists have referred to man's attainment of the erect position as the beginning of a new epoch, and have shown how walking upright upon the earth would affect not only hands and feet, but brain and vocal organs. The picture usually suggested is that of "the turning of an ordinary quadruped a quarter of a circle into the vertical plane," and we are asked to think of the "slow and painful acquisition of a radically new posture." It must be noticed that bipedal progression has originated many times over -in giant reptiles like the great Iguanodons (such a striking feature of the Museum of Brussels), in birds, in kangaroos (if they are not tripods), in the jerboas of the desert, and in other adventurous types. Saville Kent has given a lively description of a bigcollared Australian lizard (Chlamydosaurus) which gets up on its hind legs, takes a little tottering run, and collapses like a baby learning to walk. Such cases are interesting, for they warn the zoologist against being too sure about what a living creature cannot do. Bipedal progression has been tried over and over again, and we may witness, though with anything but pleasure, the possibilities of 
it in performing bipedal dogs and bears. But bipedal progression is one thing and the upright position is something more. The problem is: What induced man and his relatives to attempt it and persevere in it successfully? We think that the answer is given in Professor F. Wood Jones' recent brilliant study of "Arboreal Man," and in an earlier not less brilliant study by Dr. R. Anthony, a French zoologist.

Professor Wood Jones has worked out very convincingly the thesis that Man had no quadrupedal ancestry, but that the Primate stock to which he belongs was, from the first, bipedal and arboreal, and that the leading peculiarities of man and his distant relatives were wrought out during a long arboreal apprenticeship. When we say "from the first" we mean from the time when the Primate race diverged from a stock of generalized placental mammals, or from a stock of bipedal arboreal reptiles, represented perhaps by some of the extinct Therapsids. It is interesting to remember the view of some experts that birds were also evolved from an ancient stock of arboreal reptiles. All these pedigrees are hidden in the mist, but this need not hinder a discussion of the organic lessons that may have been learned in the primeval school of the tree-tops. The first great gain of arboreal life on bipedal erect lines (and not in the fashion of sloths, bats, and the like) was the emancipation of the hand. The typical quadruped needs its fore limb as a stable supporting pillar and organ of progression upon the earth, but 


\section{MAN'S ARBOREAL APPRENTICESHIP 289}

what a door was opened by the division of labor that made the foot the supporting and branchgripping member, and set the hand free to reach upward, to hang on by, to seize the fruit, to hug the young one close to the breast!

On that tack of evolution, everything we value depended on setting the hand free from the supporting function and yet keeping it generalized and plastic. For the human hand, so often misunderstood, remains a generalized structure, able for anything. "In bones and in muscles," Dr. Wood Jones says, "the human fore limb is far more like that of a tortoise than it is like that of a horse or a dog." There is some sense, indeed, in the adage: "Good for everything is good for nothing," but the other side of it is seen in the plasticity of the unspecialized human hand. The opposite extreme is seen in the bat's hind leg, which was also freed from the supporting function, but became specialized into a mere hook by which the creature hangs itself up to sleep. For us the important event was the emancipation of the hand, and the fact that the hand thus set free was plastic and generalizedopen to adventure.

The arboreal life, with an emancipated hand, led on to an increased freedom of movement of the thigh on the hip joint, to an adjustment of the backbone as a supple yet stable pillar with a characteristic curve in the region of the loins, to an adaptation of musculature for balancing the body on the leg, to a well-developed collar-bone, to a specialization of 
thumb and big toe for branch-gripping purposes. Dr. Wood Jones sets one thinking when he notes that some rodents (e.g. the tree mouse, Mus ramgarettce, discovered by Dr. Charles Hose in Borneo) have developed very perfectly opposable thumbs and big toes upon lines exactly similar to the Primates. For this phenomenon of "convergence "-the attainment of closely similar adaptations by unrelated types-is of surpassing interest. We have dealt with it in a previous study, and referred to the discussion of the problem by Professor Arthur Willey in his Convergence in Evolution (I912), and also by Professor Henri Bergson in his Creative Evolution (I9II), but the whole riddle has not yet been read.

The evolution of a free hand, able to grasp the food and lift it to the mouth, made it possible to dispense with protrusive lips and gripping teeth, and thus there began the recession of the snout region, and the correlated enlargement of the brain box and the bringing of the eyes to the front. There is often a tax to pay for great improvements, and "the process of shortening of the snout, outstripping the process of reduction of the dental series, gives rise to one of the great problems of modern dentistry-the proper treatment of the many evils arising from overcrowded jaws." Moreover, with the reduction of the lower jaw modern man seems to be in some danger of losing his chin, and Professor Wood Jones does not look with pleasure at the prospect of "the dawn of a chinless aristocracy." 
But to return to the branches, another arboreal acquisition was a greatly increased power of turning the head from side to side. All ordinary mammals can say "yes," raising and lowering their heads; but the ability to say "no" with emphasis was gained by the arboreal Primates. And it was a great advantage to be able to move the head so as to locate sounds and supplement the mobility of the eyeballs. To arboreal life are also due, according to the anatomist, flat chests and flat backs; and whereas the breathing movements of the ribs count for most in quadrupeds, the movements of the midriff or diaphragm mean most to tree-climbers and modern man.

Except in special cases, such as marsupials and nest-makers, arboreal mammals tend to have small families, and it could not well be otherwise. In the great majority of Primates only one offspring is born at a time-a reproductive economy which would be dangerous were there not a correlated evolution of parental carefulness. All mothermonkeys carry their babies, and hold them in their arms, nursing them "in very human fashion," as Sir. Richard Owen said. The fathers, too, have repeatedly been seen carrying the young on their arboreal journeys. Now, the fact that the Simian parent has to carry the very immature baby about implies an intensification of the family relations; it must surely have favored the growth of gentleness.

On another line is the consideration that arboreal life limits the usefulness of the olfactory organs. 
Touch is separated off from the nose and snout, and is specialized in the hand. "It is the freed hand which is permitted to become the sensitive hand, which now, so to speak, goes in advance of the animal and feels its way as it climbs through life." It was a great advance when the hand began to be habitually used to corroborate or check the impressions gained by smell and by sight.

There is not much of its own body that a cat cannot see and cannot reach with its tongue, but this is far from being usual among mammals, and Professor Wood Jones is probably right in attaching considerable importance to the way in which the evolving Primate could feel with its hand over most of its body and could also picture itself. Theory apart, it is certain that the various stages of brainorganization seen among the different types of monkeys, show a decreasing importance of the cerebral area for receiving olfactory impressions and a predominance of the neopallial area where sensory impulses from hand and eye and ear stream inan area towards which, moreover, the originative seats of the outgoing motor impulses tend in some mysterious way to become approximated. It is granted, of course, that cerebral organization continued to make progress on terra firma as well as among the branches, but the point is that arboreal life was peculiarly favorable to the evolution of brains. We mean that the arboreal environment afforded peculiarly subtle sieves for the cerebral new departures which were always cropping up. 


\section{MAN'S ARBOREAL APPRENTICESHIP 293}

It may be objected that many marsupials are arboreal, and yet they do not seem to have made much of their educational opportunities. But the answer is that the ground-plan of the marsupial brain is different from that of placental mammals and precluded great advance. As to the problem whether improvement in brains brought about an increasing manual dexterity, or whether bodily improvements made possible a cerebral advance, Professor Wood Jones gives the right answer, that the two sets of improvements went hand in hand. "The evolution of the free and mobile fore limb in arboreal life may be likened to the production of a musical instrument-an instrument upon which it is impossible for the animal to produce a full range of harmony, or to appreciate the psychical connotations of this harmony, unless adequate cerebration is developed coincidently." Perhaps a somewhat similar answer may be given to the question that confronts us at every turn: How all these adaptations to arboreal life could arise if functional modifications acquired by individuals are not entailed as part of the inheritance of the race. From the fountain of change hidden in the dark recesses of the germ-cells there is a welling forth of tentatives and initiatives, but it rests with the explicit organism as a genuine agent to put these variations and mutations to the test, for if this is not done they will profit nothing, and, being born before their time, will disappear unappreciated. 


\section{XXXVIII}

\section{SEQUEL TO “THE JUKES"}

\section{THERE was recently published by the}

Carnegie Institution of Washington one of the most appalling documents in Man's strangely mixed dossier - a continuation of the well-known "study in crime, pauperism, disease, and heredity" which Mr. R. L. Dugdale completed in 1877 and entitled "The Jukes." Mr. Dugdale was a quiet, reticent Englishman, resident in New York, who had a remarkable faith in political education, and was keenly interested in social problems. On an official visit to county jails in the State of New York, he was struck by finding in " $Z$ " county six prisoners, under four family names, who were blood relations in some degree. $\mathrm{He}$ interested himself in the lineage and environment of these unfortunate people, and was able to study 709 persons, 540 being of Juke blood, and 169 of " $X$ " blood who had married into the Juke family. He found that there had been I 40 criminals and offenders, 60 habitual thieves, and so on, the degenerate lot of them costing the State in seventy-five years, beginning with 1800 , far over a million dollars. What his work showed was that, given a bad hereditary. "nature" and a bad environmental " nur- 
ture," there will be a multiplication of criminality, harlotry, and pauperism. It should be noted, if it is not too obvious, that the name Juke was fictitious, so that the publication of "The Jukes"-of restricted circulation in any case-did not induce any Nemesis analogous to what follows giving a dog a bad name. But the chance discovery (in rgII) of Mr. Dugdale's original manuscript has made it possible to recover the real names, and with these as clues, but still suppressed, Dr. Arthur H. Estabrook has followed up, with all possible carefulness, the dismal story of the Jukes down to 1915. The reason for referring here to such a grim subject was expressed long ago by Huxley, when he said: "There is no alleviation for the sufferings of mankind except veracity of thought and of action, and the resolute facing of the world as it is."

In his preface to the sequel to "The Jukes," Dr. C. B. Davenport, the indefatigable director of the Laboratory of Experimental Evolution at Cold Spring Harbor, gives a picture of the headquarters of the Jukes when their history as a strain began. "Into an isolated region, now within two hours' railroad journey of the nation's metropolis, there drifted nearly a century and a half ago a number of persons whose constitution did not fit them for participation in a highly-organized society." There were, of course, various degrees of inadequacy; and the retired, well-wooded, and well-watered valley (one thinks of "The Country of the Blind") doubtless gave many of the immigrants a chance to 
pull themselves together. But strains with damnosa hereditas had been "assisted out" from Europe, and from such, foreordained to perdition, came "the Jukes." Here are some of them: Max, the hunter and fisher, the jolly, alcoholic ne'er-do-well; Lem, the stealer of sheep; Lawrence, the licentious, free with his "gun"; Margaret and Delia, the wantons; and Bell, who had three children by various negroes. Dr. Davenport continues: "Not only was much of the original stock bad, but improvement which might otherwise have occurred was prevented by constant inbreeding. The nervous weaknesses, the mental insufficiencies were thus brought together from both sides, and mentally and morally defective offspring were rendered more certain. Some outbreeding there was, and where it was with better stock the progeny had better intelligence and emotional control, and lines were founded that were able to hold a good position in organized society."

The sequel deals with the now widely-scattered descendants of five original Juke sisters, a total of 2094 people, of whom $125^{8}$ were living in I9I5. The most general fact about them is that one-half were and are feeble-minded in a wide sense, "mentally incapable of responding normally to the expectations of society, brought up under faulty environmental conditions which they consider normal, satisfied with the fulfilment of natural passions and desires, and with no ambitions or ideals in life." As to the other half of the Jukes, 
who could not be called feeble-minded, their history seems to have varied mainly-as does that of most of us-with the opportunities of social " nurture." But all this is too vague: let us take more precise acts. In I9I5 there were 43 male Jukes between the ages of 15 and 18 ; out of 29, whose histories are adequately known, " 18 are anti-social, doing poorly in the world at large; 2 are criminal, while 7 are so obviously mentally defective as to be noticeable to the general community." It may be noted that all the Juke criminals were or are feebleminded. Of the 43 lads referred to above, i9 are industrious. The number of males over 19 and females over 15 was 705 in 1915 , and 305 (or 43 per cent.) of these are "inimical to the general welfare of the community," 4 I are criminal, Io3 mentally deficient, 83 intemperate. But I52 are industrious, and 65 are classed as "good citizens." Of these good citizens, we are told that "the bad traits which have held down their brothers and sisters have become lost, and they are the fountainheads of new families of socially good strain." The word "lost " is arresting. It may be that some of the bad traits illustrate Mendelian inheritance, and may, in the case of marriage into good stock, be entirely absent in a certain proportion of the grandchildren and subsequent descendants.

On his laborious study of the Jukes, Dr. Estabrook bases some general conclusions: cousin-matings in radically-defective stock produce defective offspring, even when the parents make a passable 
appearance; there is a clear hereditary factor in licentiousness; pauperism indicates bodily or mental weakness, and the latter is linked with criminality; penal institutions have little beneficial influence upon persons of defective mentality; one in four Jukes is improved socially by Children's Institutions; a change of environment gives the individual a new opportunity and a chance of mating into better families. In many cases, however, the ne'er-do-well in new surroundings finds another like himself. Improved social environment demonstrably counts for much in the individual's development, but this depends on the response that he is able and willing to make, and the power of response depends on the hereditary constitution. Yet " heredity, whether good or bad, has its complemental factor in environment."

Mr. Dugdale laid emphasis, as we have said, on the deteriorative effect of continuous bad surroundings; Dr. Estabrook's study, carefully documented with genealogical trees, shows that the hereditary factor is in some cases equally important, e.g., as regards weak-mindedness. It is probably unjust to trace all the innate deficiencies of later date to the original Juke strain, since evils bred in the bone would be sometimes accentuated by mating with similarly disposed members of other stocks. As to weaknesses that can be classed as Mendelian unitcharacters-a question very partially answered, it must be noted that outbreeding with normal members of the community would affect the dis- 
tribution of the characters in the progeny, but would not effect their disappearance.

The story began with five sisters, and from them has spread all this welter of weakness and misery, crime and sinfulness. And it is not in America only that Jukes abound! The facts make us feel the need for a fuller, deeper, and wider recognition of what Mr. Benchara Branford, in his magnanimous Janus and Vesta (1916), calls " that lofty principle of hereditary, collective and vicarious responsibility, punishment and suffering, inherent in the East, binding with indissoluble and adamantine chain into compassionate social solidarity generation to generation." What can be done to prevent this proliferation of evil? The suggestions before the world are fourfold. (I) The first is literally or metaphorically surgical-the sterilization of those whose constitutional deterioration is radical and indubitable. From this proposal social sentiment shrinks, partly because it is coercive and infringes "the liberty of the subject"-rather a mockery for many a poor Juke; partly because of the terrible mistakes that might be made in our ignorancewhich, however, memoirs like Dr. Estabrook's are rapidly reducing; and partly from the dread that always attaches to proposals which interfere " artificially" with " natural" consequences.

Less drastic, in a way, but also affecting the liberty of the individual, is the proposal to secure the permanent custodial care of, let us say, the feebleminded, to begin with. Dr. Estabrook writes: 
"Out of approximately 600 living feeble-minded and epileptic Jukes, there are now only three in custodial care. It is estimated that at the end of fifty years the defective germ-plasm would be practically eliminated by the segregation of all of the 600." (3) A third proposal, to be considered very critically, is to improve bad stock by letting it mingle with good. If we were able, as we are not, to distinguish beforehand between characters that blend and characters that Mendelise, it might be practicable to get a passable average man from a good mother and a bad father, but in reference to well-defined characters the trend of investigation is strongly against any such experimenting. It is probable that the very worst thing a man can do is to taint good stock with bad. The children of such unions may turn out not badly, if they are brought up in conditions of wholesome nurture, and the taint (if a unit-character) may be wholly absent in some members of subsequent generations, but without the aid of persistent selection it cannot disappear from the lineage. When children genetically sound, but by individual malnutrition weakly, are transplanted to good environment, they often do well; and if they grow up, settle down and marry, no stock is harmed. But Dr. Davenport justly doubts the wisdom of sending "much bad germ-plasm to good farming communities throughout our Middle West." Dr. Davenport has done valuable service to the science of genetics, but we wish he had not written a sentence like this: "It is probable that, 
in the long run, the cheapest way to improve a bad germ-plasm is to scatter it." For this sentence, which seems to us extremely dangerous, is almost certain to be quoted apart from its context: "I do not, however, recommend this course as superior to segregation; but only as a cheap and somewhat hazardous substitute. In the case of the Jukes there are so many dominant traits of feeble inhibition that scattering them is like scattering firebrands-each tends to start a fire in a new place." The last sentence hits the nail on the head. (4) What other suggestion is there save the ancient one, to get at the real through the ideal, to work back to the old-fashioned pride of race and pride in wholesome children, to cultivate a sense of the social or racial aspect of marriage, to foster rational prejudices against mismating, and to raise our standard of health for mind and body alike? 


\section{XXXIX}

\section{THE OPTIMISM OF PATHOLOGY}

NLY the foolish or the ignorant can speak light-heartedly of disease with its malignant subtlety and spreading trail of misery. How often the microbe blots out the sun; how often we are staggered by the corruptio optimi pessima seen in the dissolution of a structure that stood for a generation like a tower four-square to the winds; how often, in spite of the triumphs of modern medicine, the hydra-headed irrepressibility of disease grips us like a nightmare! Health is a magnificent quality, but it is ever cheek by jowl with disease; and thus arises the sinister view, of which William James spoke, that "beauty and hideousness, love and cruelty, life and death keep house together in indissoluble partnership." But without talking nonsense about the whiteness of blackness, or the goodness of evil, it is perhaps possible to bring forward some useful considerations in regard to the optimism of pathology. In the first place, there is the important fact that apart from senescence and parasites large and small, there is almost no disease in wild Nature. Should a pathological variation arise, it is eliminated before it takes grip. Constitutional disease is the occurrence of a meta302 
bolism out of place, out of time, and out of tune, and Nature makes short work of such unhandy idiosyncrasies. What then of potato disease and salmon disease, of fowl cholera and swine fever, and big-bud on our currant bushes and bee-disease in our hives? The list may be lengthened out, but the answer is probably the same in all cases, that these diseases are microbic or parasitic, not constitutional, and that they occur in artificial, humanly-contrived conditions, not in the economy of wild Nature. There are very few examples of microbic diseases in natural conditions, one of the best known being a bacterial disease in sandhoppers, and this may, for all we know, have something to do with sewage or the like. It is not denied that wild animals are sometimes widely infected with microbes so that an epidemic results. We know of a sort of diphtheria among ring-doves, and it may be that some disease was responsible for the extraordinarily rapid disappearance of the Passenger Pigeon. But what is maintained is that such occurrences are rare and evanescent, and that they are usually traceable to rapid human interference - to introducing new tenants into a region, to killing off the natural eliminators of the sickly, to permitting overcrowding, to an infection of the soil and water, and so forth. As to grouse, it seems that there is no specific disease in this well-nigh sacred bird, but that the removal of natural sifting agencies allows of the accumulation of weaklings and weaknesses. The contingent of parasites which 
seems to be kept within bounds in the vigorous bird may increase sevenfold, spreading, for instance, to new organs, and this may give the death-blow. We submit, however, that in wild Nature, "untainted by man's misery," as Shelley said, health and disease do not "keep house together in inclissoluble partnership." As to the alleged occurrence of caries in Permian fossil-fishes and osteomyelitis in a cave-bear, perhaps it is not unjustifiable to regard such cases with a little suspicion.

In the second place, are we not a little apt to forget what has been recently emphasized in Professor J. G. Adami's interesting and courageous Medicial Contributions to the Study of Evolution (I9I8), that certain uncomfortable bodily processes, often included under the category of disease, are the organism's efforts to adjust itself to what is in man's case an extraordinarily subtle and changeful environment-in great part very artificial? Thus against the old view of inflammation as essentially an injurious process leading to the destruction of tissue, we have the modern view, firmly associated with the work of Metchnikoff, that inflammation is a response or reaction to an intruding irritant, and tends to counteract its deleterious effects. The reaction may be inadequate or excessive, for the organism cannot be perfectly adapted to every casualty. But inflammation is none the less in the direction of repair and self-preservation. What we should marvel at is not human disease, but the many-sidedness of our power of counteracting the 


\section{THE OPTIMISM OF PATHOLOGY 305}

assaults of microbes and poisons. Professor Adami writes: "As shown by Sir William Leishman's simple and beautiful experiment (which formed the basis of Sir Almroth Wright's opsonic technique), there is not one pathogenic microbe which cannot be shown to be taken up and digested sooner or later by the polymorpho-nuclear leucocytes of the human blood." That our marvelously well-equipped bodyguard occasionally fails should not lead us to forget its normal success in counteracting assaults and intrusions. We are not at all convinced by Professor Adami's arguments in support of the thesis that inborn capacities for resisting disease are the hereditary outcome of individual bodily adjustments in the same direction; or that evolution, whether progressive or retrogressive, is "the outcome of an active process of continuous adjustment between organisms and their environment," if by "adjustment" is meant a direct reaction on the part of the living matter to its environment; but we think that he has done good service in calling attention afresh to the great importance of individual bodily modifications, the direct results of environmental and functional peculiarities, in showing that these are often effectively self-preservative, and in suggesting what still remains a rather vague hypothesis, that peculiarities in surrounding influences may in some way that we do not understand serve as the stimuli of variations, more deeply seated than the dents and imprints which are technically called modifications. What many will find the 


\section{6}

SECRETS OF ANIMAL LIFE

most interesting contribution of the book is the discussion of what Professor Adami calls "the law of habit." Once the cells of the body of a rabbit have got accustomed to producing a counteractive or anti-toxin to ricin (from the castor-oil plant), they may go on producing anti-ricin for weeks or months after the original stimulus. In the horse a single toxin unit of tetanus can lead in the process of immunization to the production of $1,000,000$ antitoxin units. Ptyalism may persist for a year after a dose of mercury. A cold in the head may continue for weeks after the causative agent has disappeared and thorough sterilization of the nose has been effected. The cells form a habit, it may be an entirely new habit, and it lasts, " an acquired cell variation becoming, if I may so express it, converted into a cell heredity." In somewhat the same way we may speak of microbes acquiring new habits, for the indifferent bacillus may become pathogenic, and the virulent may be tamed. But the difficulty is to pass from generations of cells and of unicellulars to the very different case of generations of multicellular animals. And even if we suppose, with Professor Adami and others, that the peculiarly modified body-cells give off specific metabolites, or hormones, or messengers of some sort, which eventually reach their goal in the germcell and thus specifically affect the offspring-say in the direction of becoming innately immune to some poison-can one say that this is as yet more than a ballon d'essai? 
In the third place, just as evil is a tax on freedom, and instability the penalty of genius, so it seems legitimate to say that constitutional disease is the seamy side of variability. Disease is often just a new departure that has gone a little beyond bounds. Sometimes it is a physiological slipping down to a lower rung of the evolution ladder. We go back to our definition that constitutional disease is a type of metabolism which is out of place, out of time, and out of tune. It is interesting to notice that what would be pathological in one animal may have become normalized in another; witness the threads from the male stickleback's kidney with which he binds the water-weeds into a nest, or the necrosis at the base of the stag's antlers which leads to their being shed. And the supra-salivation producing the material out of which the sea-swift Collocalia makes the fragile "edible bird's-nest," is it not nearly akin to ptyalism? Similarly, what is normal at one period of life may be pathological at another, as we see in the de-differentiation which occurs at certain stages in the change of a tadpole into a frog, or of a caterpillar into a butterfly. Looking backwards, we see that just as pain is in part interpretable as a self-preservative danger signal, so constitutional disease, practically absent in wild Nature, is a warning to man of the dangers of artificiality and foolhardy defiance of the fundamental principles of physiology ("fools afflicted because of their transgression," as the Psalmist put it). We see also that many processes labeled disease 
represent the organism's best efforts to counteract poison, antagonize assaults, and repair injuries. We see also that constitutional disease is after all a miss out of many hits, a failure among many successful experiments, a tax on the priceless gift of variability. So we get a glimpse of the optimism of pathology. 


\section{$\mathrm{XL}$ \\ THE CULT OF JOY}

T $N$ these days of heavy hearts (I9I7) the publication of a book on joy does not seem very appropriate, yet what Professor Dearborn, of Cambridge, Mass., has to tell us makes for the better ordering of life. For he is one of those who have followed the famous physiologist of Petrograd, Professor Ivan Petrovich Pavlov, in investigating the influence of the emotions on the health of the body. That a good circulation is associated with cheerfulness is a familiar fact-and how this organic jauntiness sometimes jars on the tired and sorrowful! But there is the converse proposition that cheerfulness makes for health. Organic harmony and vigor are correlated with gladness; the problem is whether the joy of the inner life has any real effect on the organism's working power and staying power. A merry heart goes all the day, a sad one tires in a mile; but was not the merriness the symptom of a constitutional indefatigability, and the sadness a sign of fatigue-toxins already elaborated? Dr. Dearborn seeks to prove that joy is a vera causa, and it is interesting to inquire how he does so. Needless to say, if joy be regarded as a mere luminescence or epiphenomenon of the lively. 
particles that dance unceasingly in the mazes of our colloidal substratum, then the question is prejudged. But let us rid ourselves of the mechanistic superstition and give Professor Dearborn fair play. We have our little jokes about eupeptic happiness, but our successors will smile at those who laughed at one of our author's designations, "Psychologist and Physiologist to the Forsyth Dental Infirmary for Children, Boston."

The first step in the argument is that when our joyous index is high our digestion is good. As Dr. Saleeby has put it, freedom from care has nutritive value. As was said of old time, "He that is of a merry heart hath a continual feast," and "A merry heart is the life of the flesh." Now, what the researches of Pavlov, Cannon, Carlson, Crile, and others have done is to demonstrate experimentally that pleasant emotions favor the secretion of the digestive juices, the rhythmic movements of the food-canal, and the absorption of the aliment. Contrariwise, unpleasant emotional disturbance and worry of all sorts can be proved to have a retardative influence on the digestive processes.

When the hungry man sees the well-laid table his mouth waters, but every one knows that a memory or an anticipation will also serve to move at least the first link in the digestive chain. "It. is now well known," says Dearborn, "that no senseexperience is too remote from the innervations of digestion, to be taken into its associations, and serve as a stimulus of digestive movements and 
secretions." Emotion may influence the production of adrenalin by the core of the adrenal glands, and a slight increase in this powerful substance constricts the smaller blood-vesseis, raises the blood pressure, excites and freshens the muscles, increases the sugar-content of the blood, and so on. Good news, psychical if anything is, may set in motion a series of physico-chemical and vital processes, complex beyond the ken of the wisest. And the cheerful man, who cultivates the habit of happiness, finding reasons for rejoicing in the sunshine and the stars, in flowers and birds, in works of art and the faces of his friends, will have his "joy-reward" or euphoria added unto him unless he is fool enough to pursue it.

The second line of argument refers to the circulation. Wordsworth was a better physiologist than he knew when he spoke of his heart leaping up at the sight of the 'rainbow, or filling with pleasure and dancing at the recollection of the daffodils. He may not have known much about the distribution of the pneumogastric nerve, but he knew of the influence of joy on the circulation. Experiments have been made by prevaricating physiologists who take the pulses of whole classes of students, give them milk-sugar pills, tell them that they have taken heart stimulants or heart depressants, and observe after a time the change in the pulse rates. Many of the hearts beat faster after the imaginary stimulant, and slower after the imaginary depressant, but what is more inter- 
esting is that the changes thus induced "by ideacomplexes, formed and maintained without any emotion" are small compared with those brought about by conditions predominantly emotional.

Dr. Dearborn has worked at the factors altering blood pressure, and he makes the notable statement that in the "general stimulation of the essential circulation in all constructive parts of the body, such as the brain, the muscies, and the digestive organs, joy exerts one of its most conspicuous benefits, and one that no one can doubt or ignore." It is interesting to ask, though we may never be able to answer, whether the apparent joyousness of many birds, expressed especially in song, but also in dance and exuberant flight, is correlated with their singularly perfect digestive capacity, their fine circulation and muscularity. If birds have no genuine joie de vivre, they make at times an extraordinarily good imitation of it, and we should like to know whether they are eupeptic because they are joyous, or joyous because they are eupeptic. For sometimes an organism is a mind-body and at other times a body-mind.

For man, however, there is no doubt that affective states of joy and grief cause rapid changes in blood

" pressure. "In one case," Dearborn tells us, "an imaginary kiss caused in ninety seconds a rise of at least twenty millimeters of mercurial pressure; while in another individual a suddenly recalled grief raised it in less time thirty per cent. more than that." A large variation in blood-pressure in 
persons with brittle arteries, as they so often are in advanced years, might lead to apoplexy, and the author follows Hack Tuke in referring to the alleged frequency of apoplexy in Philadelphia in the anxious winter of $1774-75$, and in Italy in 1694-95, when, as the chronicler put it, "all commerce was disturbed, and all the avenues of peace blocked up, so that the strongest heart could scarcely bear the thought of it." As the siege of Paris aged many prematurely or otherwise marked them for the rest of their days, so is it in our Great War tragedy. Therefore, though joy be far from us, we may seek to conserve our efficiency by calm fortitude. We cannot go to the "Dr. Merryman" of whom Burton wrote in his Anatomy of Melancholy, but we may seek out another whom he called "Dr. Quiet."

The third line of evidence is more difficult to follow than the two others; it has to do with the influence of joy on the nervous system. In Sherrington's phrase, the supreme function of the nervous system is integrative-that is to say, it unifies and harmoniously controls the activities of the body in relation to one another and to the environment. The question is, Can the gladsome mind increase the efficiency of this integration? It is well known that good tidings will invigorate the flagging energies of a band of explorers; that an unexpected visit will change the wearied, homesick child, as if by magic, into a dancing, gladsome elf; that a religious joy may make men and women transcend the ordinary limits of our frail humanity. 
But how is it done? How does the oil of joy, as the Scriptures call it, operate in making the limbs more supple and the face to shine?

It is an indubitable fact that a joy-say of maternity, or discovery, or artistic creation-may become an exhilaration and enthusiasm of thought and will; but the present problem is rather of the bodily welfare. It is generally believed that emotion has its physical accompaniment in strains and movements throughout the body and in changes in the secretion of glands; and it is certain that this reverberation of joy is for good, since joy is an index of the organism's well-being. It is also well-known that the æsthetic emotion--delight in the beautiful-is very markedly a body-and-mind reaction, affecting the whole creature as a unity; but the problem is whether joy does in any specific physiological way enhance the efficiency of the nervous system. Regarding the optic thalamus of the brain as a great depot of sensory influences and as a center of emotional reaction, Dr. Dearborn suggests that influences from this region may surge up into the cerebral cortex, the seat of the higher mental processes, where joy and activity are correlated. He speaks tentatively of "a strong afferent or ascending flood of neural influence through the optic thalamus (emotional 'center') into the cortical mid-layers"; but whether this means much or little, he has no manner of doubt that joy has a direct influence on the integrative function of the nervous system. 
Professor Dearborn's thesis is in a line with many other, characteristically American, studies in psychobiology, which aim at a cultivation of the personality on what one may call direct lines. The danger ahead is well known, that just as the direct pursuit of health is apt to engender hypochondria and valetudinarianism, and just as the direct pursuit of happiness is apt to defeat its own end, so the direct pursuit of joy for the sake of the " joyreward" may prove consummately futile. But it is possible to make a bogy of this risk. Forced cheerfulness is, of course, a horror, but "the persistent will to be glad," if worthily satisfied with some of the real joys of life, may soon become a habit which requires no artificial stimulation. A conventional approach to Nature and Art is often rewarded much beyond its deserts, and men who began with taking walks for duty's sake have often become genuine enthusiasts for the open country. The pursuit of joy may be futile and the faking of it an abomination, but there is nothing absurd, for instance, in humbly learning to know the endless things of beauty which are joys for ever. If we make sure of these, the euphoria will look after itself. 



\section{INDEX}

Acquired characters, question as to their transmissibility, 221-223.

Acquired vigor, does it count? $263 \cdot 269$.

Adami, Professor J. G., his studies on disease and evolution, 304, $305,306$.

Agar, Dr., his experiments, 224.

Alga, 81, 82, 86.

Allen, Dr. E. J., his demonstration of the correlaton between sunshine records and the quantity of mackerel at Billingsgate, 80 .

Allen, Glover $\mathrm{M}_{\text {, }}$, his book on Whalebone Whales, 71 . quoted, 76, 77 .

Amazon ants, raids of the, $17 \cdot 23$.

"Anguillulid Nematodes," 75.

Anguillulid worms, 179.

Anguis fragilis, 167 .

Anthony, Dr. R., French zoologist, 288.

Ants, Amazon, raids of the, 17-23.

Brown, 19, 20, 23.

maternal care of worker, 272.

Mediterranean, 186.

white, shedding of wings of, 170 .

Ants and bees, experimental work with, 7 .

Aphoenogaster barbarus, 186

Apiary, large, pleasant impression of sound of, 106 .

Armadillo, Hairy, I6ז.

Hybrid, 162.

Little, I59.

Nine-banded, I58-159, I60, I6I162.
Arromatic compounds in various plants, 96-97.

Art, before the dawn of, 278-286.

Aspergillus niger, 187.

Autotomy, I68-173

Autumn, characteristic sights of, I 13.114 .

delight and quietness of, II I-II2. problems of the natural history of, 116 .

scientific interest of, $112-113$. tactics of, 116-118.

the withering and fall of the leaves, I $14-1 \times 5$.

"Auxetics" and "augmentors," 132.

Balaena mysticetus, 78 glacialis, $7 x$.

Bataillon's method of fertilization of frog's eggs, 140 .

Bateson, 232, 240.

"Beagle," Voyage of the, quoted, $82,93$.

Beavers, $27 \mathrm{x}$.

Becquerel, M. Paul, his experiments on seeds $177-182$

Beddard, Dr. F. E., on whales, 78.

Bees, storing instinct in, 184,185 . worker, maternal care of, 272.

Beetles, Burying, limitation of their instinct, 209.

Before the dawn of art, 278-286.

Bergson, Professor Henri, on instinctive behavior, 2 ro on the resemblance between the 
scallop's and the vertebrate's cye, $257 \cdot 258$.

quoted, $230,290$.

Bernard, Claude, his work on the phenomena of life, r78-r79, 180.

Biology, of spring, $15 \%$. of twins, $158-165$.

Bipedal progrcssion, 287-288.

Blackburn, Mrs., accuracy of her drawing of young cuckoo clearing nest by force, 46 .

Blegvad, Dr., on detritus-eating creatures, 86.

Bonhote, J. Lewis, his breeding ex. periments, $265 \cdot 266$.

on vigor and heredity, 264,266 269.

Boulenger, Dr., quoted, on frogs, 47.

Brachet, Professor, his lectures on the egg, I $34,136,138$.

Brandt, Professor, on Plankton in polar and tropical seas, $85-86$.

Branford, Benchara, quoted, 299.

Brer Rabbit's policy, I 28.

Bullen, G. E., his demonstration as to the correspondence between the catches of mackerel and the amount of Copepod plankton, 80.

Burroughs, John, quoted, 2\$8.219, 262.

Burton, Robert, quoted, 313 .

Butler, Samuel, quoted, 25, 223.

Casar, the motive of his expedition into Britain, 67.

Cairngorms, their slopes in winter, I 27, I 29, I32.

Caterpillars, Procession, their in. stinct limited, 210.

Cave blindness, the problem of, 246-253.

Cerambyx beetle, grub of, 208-209. Chamberlin, Professor, on the ori- gin of life on the earth, $21_{4}$, $217,218$.

Chambers, Robert, on the embryo, 148.

Change, the fountain of, 238-245. the problem of what brings it about, 238-239.

Characteristic sounds of particular places, 108-109.

Cheerfulness. See Joy.

Child, Professor W. M., on senescence and rejuvenescence, I5I, 153.157.

Chimpanzee, restless habits of, I95.

Chlamydosaurus, 287.

Chromosomes, number of, 136, 137, 1 $38,242-243,244$.

Claparède, 285 .

Cod, journeyings of, 196.

Convergence in evolution, 254-262. of Australasian animals, 256.257. three suggestions with regard to, 259-26r.

Copepod plankton, $80,81,84,87$.

Correns, 232.

Country sounds, I04-110.

Cowrie shells and symbolism, 64, 68-70.

Crab, common, journeyings of, 196.

Crime. See Sequel to "The Jukes."

Crustaceans, autotomy in, $170-172$. freshwater, their survival of drought, $\quad x \neq 6$.

Cuckoo puzzles, $39-46$.

Cuckoos, resentful attitude of hedge-sparrow and little birds to, $40-41$.

resemblance of eggs to selected foster-parent, 44 .

securing success for their off. spring, 272.

smallness of their eggs, 44 .

their abundance in 1916,39 .

their calls, 39-40.

their evasion of brooding, $41 \cdot 43$. 
young cuckoo's behavior in nest, $44-46$.

Cyon's theory, that birds nose their way home through the air, 6 .

Dakin, Dr. W. J., on the food of the Copepods, 81 .

Darwin, Charles, going forward with, 225-228.

on brain of the ant, 134 .

Darwin, Charles, on earthworms, 184.

on heredity, 229.

on kelp, 93.

on two Roman snails, 55 .

on water discolored by minute floating Algx, 82.

referred to, 206 .

Darwinism, no recantation of, $224^{\circ}$ 225.

Davenport, Dr. C. B., his studies on "rovers," 191-196.

on "The Jukes," 295-296, 300301.

De Vries, a rediscoverer of Men. delian clue, 232.

his study of mutations and their behavior, 240-241.

Dearborn, Professor, observations on his book on joy, 309.315.

Delage, Professor Yves, his method of subjecting ova to chemical action, 140 .

Diatoms, $81,82,87$.

Differences in degeneration of eyes of cave animals, $247 \cdot 248$.

Digger-wasps, 270, $271,273$.

Dinnet, the moor of, in spring, 150.

Disease, almost none in wild Nature, 302.

the organism's efforts to adjust itself to environment, 304 .

the seamy side of variability, 307 .

Doflein, 248.

Duchãtel's hypothesis as to sensitiveness of retina of bird, 5 .
Dugdale, R. L., his studies on "The Jukes," 294.295.

Earland, Mr., his investigations on shells, 282,283 .

Earth, the, "preparations" that make it fit for a home for living creatures, $213-216,217$ 220.

Earthworms, storing instinct in, 184 .

Ebrard, incident of the ants' cocoons reported by, 20.

Egg, the microcosm of the, $134^{\circ}$ $14 \mathrm{I}$.

Eigenmann, Professor, his study of cave-fishes, 250, 252.

Embryos, dwarf and Siamese-twin, 141.

Emery, Professor Carlo, his investigations on the European Amazon ant, 17:23.

Estabrook, Dr. Arthur H., his sequel to the story of "The Jukes," 295, 297-300.

Eumenes amedei, 207, 208.

Euphausia, penguins' food, 13.

Evening Primrose, mutations of, $240,241,242$.

Evolution, convergence in, 254.262.

Evolution of the free hand, 288 . 293.

Experiments on egg-cells, 140-14I. on homing of sea-swallows, $1-8$. with ants and bees, 7 .

Ewart, on seeds, 179.

Fabre, the late M. Henri, lis ob. servations on beetles, 185 .

his observations on wonders of instinct, 206-210.

Fall of the year, III-II9.

Fall of the leaves, 114-115.

Fish embryos, experiments on, 250, 251.

"Floating meadows," 81-82, 88. 
"Fluctuations" and "mutations," $238-240$.

Foraminifera or chalk-forming animals, 278-281, 284 .

Forel, Auguste, his observations on ants, 18, 20, 22.

Formica sanguinea, blood-red ant, 17.

Foster, Sir Michael, quoted, on the living body, 104.

Frankincense and myrrh, 95-102.

Fremiet, M. Fauré, on the egg, 136.

Frog, life-cycle of, 47-54.

Frogs' eggs, artificial parthenogenesis of, 140 .

Gadow, Dr., quoted, on the frog, 47. Gain, Dr. Louis, on penguins returning to same rookeries to breed, II.

Galton, Sir Francis, his insistence on the reality of transilient variations, 240.

his investigations on biology of twins, $x 62-164,165$.

his studies of inheritance, 230 23 I

referred to, 223.

Gates, Dr. Ruggles, his investigations on mutation of Enothera, 242-245.

Geddes, Professor Patrick, his idea as to life-curve, 143.

Giard, Professor, 176.

Gladstone, Hugh S., his observations and statistics on rooks, 38 .

Globerigina, 279.

Goal, the unseen, the way in which animals persistently work towards, $270 \cdot 277$.

Goethe, quoted, 276 .

Goldfishes, experiments on, 249 .

Gorilla, restless habits of, 195 .

Graham, Thomas, on "energia," 216.
Groos, Dr., 149.

Gudernatsch, his experiments on tadpoles, 147.

Hedge-sparrow shadowing and attacking cuckoo, 40.

Heine, his definition of silence, 106.

Hempelmann, Dr., quoted, on the frog, 54 .

Henderson, Professor, on the origin of life on the earth, 214, $215,216,218$.

Henri, Mme., her experiments on the bacillus of anthrax, 241.

Herdman, Professor, quoted, on Diatoms, 82, 87 .

Heredity. See Sequel to "The Jukes."

Heron-Allen, Edward, his observations on sheils, $278-286$.

Herrick, Professor F. H., his sug. gestion as to cuckoos' loss of nesting instinct, 43 .

Hippocampus, 256.

Hoimes, Professor, quoted, on evolution of the voice in vertebrates, 49.

Homing of birds, problem of, I.

Hookham, George, 226, 259 note.

Hose, Dr. Charles, 290.

House-that-Jack-built nutritive chain of sequences, $87,91-92$.

Huber, Pierre, Swiss entomologist, $18,22$.

Huxley, quoted, on organisms, 103.104.

on oysters, 64 .

on the cycle of life, 142 .

on the sufferings of mankind, 295.

Hyper-sensitiveness to sounds, I03, I07.

Inflammation, 304 .

Instinct, different from intelligence, 210-2II. 
its limitation in insects, 209-210. wonders of, 206-21 2.

"Intelligence" of Foraminifera in their shell-formation, 278 .

Jackson, Wilfrid, his work on shells, $63,66,68$

James, Professor William, his two. fold division of mankind, $84-85$.

quoted, 302.

Janet, $M$. Charles, his formicaria of brown ants, 19.

Jenner, his observations on young cuckoo in nest, $44.45,46$.

Jones, Professor F. Wood, observations on his study of "Arboreal Man," 288-293.

Joy, its influence on the circula. tion, 311 .

its influence on digestion, $3 \times 0$.

its influence on the nervous system, 313.

the cult of, 309.315.

"Jukes," the, sequel to, 294-30r.

Kammerer, Dr., his experiments on salamanders, $224 \cdot 225$.

Kelp, 93 .

Kidd, Benjamin, on artificial nur. ture, $164^{-165}$.

Kirkman, F. B., his notes regarding male birds and their mates, 34 , 36.

his comparison of cuckro's notes, 40:

Lachmann, 285.

Lamarck, getting back to, 221, 223, 224.

Lankester, Sir Ray, referred to, 29, $6 \mathrm{I}, 206,223,255$.

Lashley, Dr. K. S., his experiments on homing of seaswallows, 1.8 .

Latter, O. H., quoted, on frogs, 47.
Leishman, Sir William, 305.

Levick, Staff-Surgeon Murray, R. N., his observations on the Adélie penguins, 9-16.

Liebig's idea of the circulation of matter illustrated, 81 .

Life, a limb for a, 166-174. embryonic period of, 145 . larval period of, 142, 144 . latent, $175-182$.

the curve of, $142-149$.

varying types of, 147-149.

Limb for a life, a, 168-174.

Loeb, Professor Jacques, his experiments on fishes, $250,25 \mathrm{I}$ 252.

his method of subjecting ova to chemical action, 140.

on Plankton organisms, 86.

Mackerel, 80, 81, 88.

Macquenne, experiments on seeds, 180.

Macrocystis pyrifera, 93 .

Making a home for life, 213-220.

Man's arboreal apprenticeship, 287 . 293.

Marsipella cylindrica, 285. spiralis, 285.

Maspero, M., his non-success in germinating wheat grains from tombs of the Pharaohs, 179.

Mayfiower's encounter with whales, story of, 76 .

Mendel, the experimental work of, $230,232.23 \%$.

Mendeléeff, 217.

Mendelian classification of all new characters into dominants and recessives, 243.

Mendelian clue, the, 231-237.

its rediscovery, 232.

Mendelian conception of inherit. ance, its three fundamental ideas, 232.235 .

Mendelian doctrine, 244 . 
Meredith, George, quoted, I0, IIo, 203.

"Metabolism," 264-265, 268.

Metchnikoff, on cause of growing old, 152.

on inflammation, 304 .

Microcosm of the egg, I34.14I.

Midwinter, I27-1 33 .

Milton, quoted, 76,130 .

Mitchell, Dr. Chalmers, 149.

Modifications, 305 .

Moore, Professor Benjamin, on contents of sea-water, 83 .

Morgan, T. H., his experiments on the fruit-fiy, 236 .

Murray, Sir John, quoted, $81-82$, 86.

Mus ramgarettae, 290.

Nansen, in Far North, 127. on restless men, 195 .

Natural selection of variations a vera cause in evolution, 225, 227-228.

Neger, on ants' food, 187 .

Nematodes, in food-canal of grouse, 201.

Newman, Horatio Hackett, on biology of twins, 158-162.

Newton, Professor, his theory as to cuckoos' egg*, 44, 45.

Noddy terns, homing experiments on, $x-6$.

Noisiest thing in the world, ro3.

Nomadism, 191-197. two kinds of, 195.

Norman, Canon, on shells, 282.

Odoriferous gland in shrews, 99.

Odoriferous substances, in butterflies and moths, 97.

in hound's tongue and mice, 100 ror.

in insects, 98, 99.

in plants, $95-97$.
Odors of mammals and reptiles, 98.

CEcotrophobiosis, nutritive exchange, 29,31 .

Enothera lamarckiano, 240, 241, 243.

Ogneff, his experiments on goldfishes, 249.

Onneas, M. Kammerlingh, his re-

frigerating laboratory, 180 .

Onychophera, 145.

Otter, its catholicity of appetite, 121. its intensity of parental care, 122. its playfulness, 123 .

its resourcefulness, 124 .

its roving spirit, 124 .

its scent, $12 \mathrm{r}$.

its test-time during prolonged frost, 125 .

the survival of the, I20-1 26 .

Owen, Sir Richard, 291.

Parasites, differences of, 199-200. effects on hosts, $20 \mathrm{x}$. great mortality from, 202. repulsiveness of, 202-203.

"wildness" and devilry of, 204.

Parasitism, the problem of, $198-205$.

Parker, Professor G. H., quoted, on sense organs, 100.

Parthenogenesis, artificial, I 39-140. Pathology, the optimism of, 302 308.

Paul, J. Herbert, his work on Crustaceans, $170,172$.

Pavlov, Professor Ivan Petrovich, his experiment on mouthwatering of dog, 56-57.

his investigations on emotions and bodily health, 309, 3 ro.

Pearls, 66-68.

Pearson, Professor Karl, his study of inheritance, 231.

Penguins, Adélie, observations on the habits of, 9-16.

Peridinians, 8r, 87. 
Petersen, Professor C. G. Joh., on sea-bottom meadows of Danish waters, 89-94.

Petersen and Jensen, Danish naturalists, on organic matter of sea-floor, 83 .

Phalangidæ, $169-170$.

Physa gyrina, common watersnail, 56.

Phyto-plankton, 81, 82, 86.

Planarian worms, $153^{-1} 54$.

Plankton organisms, $83,84,86,89$, 90.

Polyergus rufescens, slave-owning ant, 18.

Pond-life in winter and spring, 132.

Primates, 288, 290.292.

Problem of cave blindness, the, 246-253.

Problem of the origin of the distinctively new, 238 .

Progressiveness of evolution, $22 \%$.

Proliferation of evil, four suggestions to prevent the, 299.301.

Proteus, 247, 249, 274 .

Psammosphæra, 283.

Ptyalism, 306, 307.

Purple dye from sea-sinails, 65-66. Pütter, Professor, his heresy as to sea-water, 83 .

Rane esculenta, 48. temporaria, 47.

Raspail, on young cuckoo's conduct in nest, 45 .

Rejuvenescence, 150-157.

Reophax, 281.

Riddle, Professor Oscar, 538.

Rignano, editor of Scientic, 223.

Robinson, Phil, his observation as to parent birds" "peptoniza. tion" of food for young, 36 .

Rooks, cawing of, 32-38.

their courtship, nesting, eggs, and habits, 34-38.
Roubaud, Dr., bis discoveries as to domestic economy of African wasps, 26-31.

Roving impulse, the, 191-197.

Saleeby, Dr., quoted, 310.

Salmon, in autumn, 113.114.

Sea, internal economy of the, 80-87.

Sea.cucumbers, 169.

Sea-grass, 89-94.

Sea-meadows, 82, 88-94.

Sea-swallows, homing of, 1.8 .

Seeds, dried, 177.

experiments on, $177,180-181$.

germinative power of, 179 .

their capacity for lying low, $18 \mathrm{~s}$. 182.

Selous, Edmond, quoted, on rooks' cawing, 33 .

Senescence, $151 \cdot 152,154^{-1} 57$.

Senility, $151 \cdot 152$.

Sense of smell, differentiated from that of taste, 99 .

in insects, 98 .

in man, 95-102.

in the $\operatorname{dog}, 99$.

Sense of taste, 99, 100.

Sequel to "The Jukes," $294 \cdot 30$.

Shakespeare, quoted, $87,197$.

Shelley, quoted, 304.

Shells, the appeal of, 62 .

the cult of, 62-70.

the delight in, 62 .

their decorative value, 64 .

their interest to students of hus man history, 63.

their practical value for food, 64 . their psychological value as symbols and charms, 64, 66-70.

Shell-trumpet, 64-65.

Sherrington, Professor, quoted, 99. 313.

Shipley, Dr., 198.

Siamese twins, 141, 159, 160.

Smith, Professor Flliot, on the cult of shells, 63, 68, 69 . 
Snail, experiments and investiga. tions on educability of, $55^{\circ}$ 61.

Sooty terns, homing experiments on, $1-6$.

Sounds, country, generally restful and subdued, $103,105$.

Spencer, Herbert, runs away from home at thirteen, 192.

his conviction that a right answer must be given to the question whether acquired characters are or are not inherited, 221 .

Spring, biology of, $15 x$.

its coming, on the moor of Dinnet, 150.

Squirrels, their storing instincts, 188.

Starfishes, shedding a limb, 166 , 167,169 .

Stevenson, R. L., quoted, 113.

Storing instinct, $183-190$.

among birds, 187.

among insects, 184-187.

among mammals, 188-189.

in man, 189-190.

Story as to "young seals" being "so like birds," 9.

Stout, Professor, quoted, on smell, 101.

Sweet Vernal grass, 95.

Tadpoles, Gudernatsch's experiments on, 147.

their power of regrowing parts, 168.

See also Frog.

Tapeworms, 198, 200.

Technique of the experiments on homing of sea-swallows, 2 .

Technitella, 280, 282, 284, 286.

Thompson, Miss Elizabeth Lockwood, her experiments on snails, 56-61.

Tower, Professor, his experiments on potato-beetles, $24 \mathrm{I}$.
Tregarthen, J. C., his observations on the otter, 120-126.

Troglodytes, $246 \cdot 247$.

Trypanosomes, 198, 202.

Tschermak, 232.

Twins, biology of, 158-165.

Galton's investigations on, 162 164.

Siamese, 159.

similarity between, $162 \cdot 164$.

Van Hoff's law of the effect of temperature on chemical reactions, 129.

Verhoeff, on wasp-community, 30 .

Vigor, acquired, does it count? 263.269.

Vigor and Heredity, Mr. J. Lewis Bonhote's book, 264-265.

Wasp, solitary, its perfection of nest, $207 \cdot 208$.

Wasps, African, 26, 28-31.

social life of, 24-31.

their family coherence, strength, and ingenuity, 25-26

their instinctive behavior, 270, 271.

their wonderful workmanship of their nest, 24-25, 115.

Watson, Professor J. B., his experiments on homing of seaswallows, 1.8 .

his observations on the duration of the nesting impulse, 7 .

Weismann, Professor, 155, 223, 229, 230, 255.

Werber, his physiological theory, 161 . Whales, Baleen, 72, 73 .

Black North Atlantic or Biscay, 7I, 75.

Black Right, 78 .

Finback, 7x.

Greenland, or Bowhead, 78 .

Humpback, 71.

Right, the fitness of, 71.79.

Whales, Sperm, 71. 
story of Mayflower's encounter with, 76 .

their extraordinary adaptations, $71-73$.

Toothed, 71 .

Wheeler, Professor W. M., his studies of American Amazon ants, $18,277$.

White, Gilbert, quoted, 34, 184 .

Whitman, Walt, his "World below the Brine," quoted, 94.

quoted, on the bustle of growing wheat, 104 .

Willey, Professor Arthur, on convergence in evolution, 256, 260-261, 290.

Wilson, Professor E. B., on Siamese-twin embryos, 160 .

Wilson, Professor James, on Mendelism, 235-237.

Wilson, the late Dr. Edward A., his work, 10.

"Wireless" messages of imagina. tion, 109.
Winter, birch trees in, 129 . on the slopes of the Cairngorms, $127,129,132$. pond-life in, 132 . silence of, 127 . stores to tide over, I3I. time of rejuvenescence, 128 . vital activity and its breakingpoint in, 130. ways in which living creatures meet stress of, 130-131

Wonders of instinct, 206-212.

Wordsworth, 4I, $3 \mathrm{Ir}$.

Worms, Anguillulid, 179. self-mutilation of, when captured, 168-169.

Wright, Sir Almroth, 305 .

Zoo, story of lady and the penguins at, 9 .

story of Yankee visitor at, with regard to the giraffe, 73 .

Zostera, sea-grass, 89, 90, 9r. 

w

- 




